Pontifícia Universidade Católica
do Rio de Janeiro

José Teles Mendes

Liberalização e universalização

Tendências do welfare state brasileiro após a

Constituição Federal de 1988

Dissertação de Mestrado

Dissertação apresentada ao Programa de Pósgraduação em Ciências Sociais da PUC-Rio como requisito parcial para obtenção do grau de Mestre em Ciências Sociais.

Orientador: Prof. Fernando Cardoso Lima Neto

Rio de Janeiro 


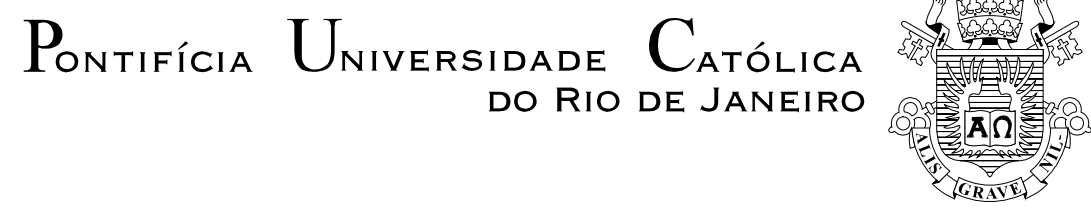

José Teles Mendes

\section{Liberalização e universalização Tendências do welfare state brasileiro após a Constituição Federal de 1988}

Dissertação apresentada como requisito parcial para obtenção do grau de Mestre pelo Programa de PósGraduação em Ciências Sociais do Departamento de Ciências Sociais do Centro de Ciências Sociais da PUCRio. Aprovada pela Comissão Examinadora abaixo assinada.

Prof. Fernando Cardoso Lima Neto

Orientador

Departamento de Ciências Sociais - PUC-Rio

Profa. Elisa Maria da Conceição Pereira Reis

UFRJ

Prof. Luiz Jorge Werneck Vianna

Departamento de Ciências Sociais - PUC-Rio

Profa. Mônica Herz

Coordenadora Setorial do Centro de Ciências Sociais - PUC-Rio

Rio de Janeiro, 9 de março de 2017 
Todos os direitos reservados. É proibida a reprodução total ou parcial do trabalho sem autorização da universidade, do autor e do orientador.

\section{José Teles Mendes}

Graduou-se em Ciências Sociais pela Fundação Getúlio Vargas (FGV-RJ). É estudante do Programa de PósGraduação em Ciências Sociais da PUC-Rio (PPGCIS/PUC-Rio), pesquisando políticas públicas e bemestar social no Brasil contemporâneo.

Ficha Catalográfica

Mendes, José Teles

Liberalização e universalização : tendências do welfare state brasileiro após a Constituição Federal de 1988 / José Teles Mendes ; orientador: Fernando Cardoso Lima Neto. - 2017. 102 f. ; $30 \mathrm{~cm}$

Dissertação (mestrado)-Pontifícia Universidade Católica do Rio de Janeiro, Departamento de Ciências Sociais, 2017.

Inclui bibliografia

1. Ciências Sociais - Teses. 2. Políticas sociais. 3. Constituição Federal de 1988. 4. Nova República. 5. Políticas públicas. 6. Welfare state. I. Lima Neto, Fernando Cardoso. II. Pontifícia Universidade Católica do Rio de Janeiro. Departamento de Ciências Sociais. III. Título. 


\section{Agradecimentos}

Aos meus pais, Marco e Marlene, que me deram toda a sustentação e afeto necessários para que eu pudesse realizar este trabalho.

Aos meus avós, Joel e Gilda, que sempre me acolheram com muito amor e mostraram a importância crucial da família.

Ao meu orientador, professor Fernando Cardoso Lima Neto, pelo apoio e diálogo constante, sempre acreditando que este trabalho seria possível.

Aos professores Luiz Werneck Vianna e Elisa Reis, que tão prontamente aceitaram os convites para participar das bancas de qualificação e defesa, pelos comentários, críticas e sugestões que tanto me auxiliaram.

Aos amigos, pelas risadas, papos, desabafos e conselhos.

Aos companheiros de jornada das Ciências Sociais, pelas conversas e debates. 


\section{Resumo}

Mendes, José Teles; Lima Neto, Fernando Cardoso. Liberalização e universalização: tendências do welfare state brasileiro após a Constituição Federal de 1988. Rio de Janeiro, 2017. 102p. Dissertação de Mestrado Departamento de Ciências Sociais, Pontifícia Universidade Católica do Rio de Janeiro.

O objetivo deste trabalho é contribuir para a interpretação das transformações no welfare state brasileiro durante a Nova República (1988-2016). Nesse sentido, o estudo parte de uma rápida discussão a respeito dos regimes de welfare, com base em Esping-Andersen (1990), seguindo por uma greve releitura da história das políticas sociais brasileiras para, então, dedicar-se ao estudo do período posterior à Constituição Federal de 1988. O trabalho, assim, propõe uma leitura alternativa das transformações recentes da seguridade social no país a partir de obras já consagradas sobre o tema. Essa bibliografia ora enfatiza uma suposta guinada universalista da proteção social no país, engendrada pelos preceitos contidos na $\mathrm{CF}$, ora um processo de liberalização, visível, por exemplo, na relação público/privado na saúde. A hipótese a ser defendida consiste na perspectiva de que essas duas tendências são simultâneas e não excludentes, partindo tanto de inovações institucionais da gestão do PT, como o Programa Bolsa Família (PBF), como de determinações constitucionais, como o Benefício de Prestação Continuada (BPC), além de serem influenciadas também por iniciativas anteriores, entre elas o fortalecimento do ramo privado de saúde realizado pela ditadura militar. Por fim, a dissertação propõe que esses dois caminhos, comumente vistos como opostos, teriam, na verdade, complementaridade, como na articulação entre o PBF e o BPC no combate à extrema pobreza.

\section{Palavras-chave}

Políticas sociais; Constituição Federal de 1988; Nova República; políticas públicas; welfare state. 


\section{Abstract}

Mendes, José Teles; Lima Neto, Fernando Cardoso (Advisor). Towards liberalism and universalism: patterns of change of the Brazilian welfare state in the New Republic (1988-2016). Rio de Janeiro, 2017. 102p. Dissertação de Mestrado - Departamento de Ciências Sociais, Pontifícia Universidade Católica do Rio de Janeiro.

This work aims to contribute to the interpretation of the transformations regarding the Brazilian welfare state during the New Republic (1988-2016). The study starts with a short discussion on Esping-Andersen's (1990) concept of regimes of welfare, following with a brief reconstruction of the history of Brazilian social policy in order to, lastly, dedicate itself to the analysis of the period launched by the Federal Constitution of 1988. This dissertation, then, proposes an alternative interpretation of the recent changes of the Brazilian social security scheme. According to this view, there is a simultaneous twofold trend regarding the national welfare state that points towards the expansion of both liberal inspired and social-democratic inspired social policy. The first trend would have its origins in public policy decisions made by democratic elected governments after 1988 and in options made by past regimes, especially the military dictatorship. The second would rely more on the spirit of the Federal Constitution, whose social precepts are strongly universalist. Finally, this work proposes that those two routes, which are usually regarded as opposed, actually have some complementarities, as one can see through the joint action of Programa Bolsa Família (PBF) and Benefício de Prestação Continuada (BPC) against extreme poverty in recent years.

\section{Keywords}

Social policy; Brazilian Federal Constitution of 1988; New Brazilian Republic; publicy policy; welfare state. 


\section{Sumário}

$\begin{array}{ll}\text { 1. Introdução } & 10\end{array}$

2. História e regimes de welfare 12

2.1. Introdução 12

2.2. O percurso histórico dos welfare states europeus 13

2.3. Regimes de welfare 22

2.4. Considerações finais 34

3. O desenvolvimento histórico das políticas sociais brasileiras 36

3.1. Introdução 36

3.2. Uma breve história das políticas sociais brasileiras da Primeira República à ditadura civil-militar 37

$\begin{array}{lll}\text { 3.3. Considerações finais } & 61\end{array}$

4. As políticas sociais brasileiras após a CF de 1988

4.1. Introdução 64

4.2. A proteção social na Nova República (1994-2016) 65

4.3. Na direção de uma síntese das transformações recentes do welfare state brasileiro

5. Considerações Finais

6. Referências bibliográficas 


\section{Lista de tabelas e quadros}

Tabela 1 - Benefícios oferecidos por IAPs selecionados nos anos $1940 \ldots \ldots . .45$

Tabela 2 - Número de benefícios da Previdência por tipos ..........................52

Quadro 1 - Número de benefícios da Previdência por tipos.........................53

Quadro 2 - № de famílias beneficiárias do PBF .....................................75

Quadro 3 - Valor total de repasse do PBF (em bilhões) ............................76

Quadro 4 - Evolução da quantidade total de beneficiários do BPC ..............77

Quadro 5 - Valor total de repasses para o BPC ........................................78

Quadro 6 - Variação do salário-mínimo em termos reais (1995-2016) ..........79

Quadro 7 - Variação percentual do PIB ............................................... 81

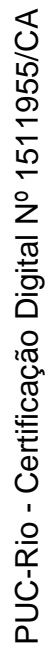

Quadro 8 - Gastos com consumo de bens e serviços de saúde,

como percentual do PIB, por setor, Brasil, 2000-2013 .89 
E como a História ainda não terminou, ninguém pode estar seguro de quem será o último a rir ou a chorar.

Celso Furtado 


\section{Introdução}

O objetivo desta dissertação é contribuir para a interpretação das transformações na proteção social brasileira, especialmente assistência social, saúde e educação, após a Constituição Federal (CF) de 1988, principalmente durante os governos Lula e Dilma (2003-2016). Nesse sentido, o estudo parte de obras já consagradas no campo do welfare state para, então, propor uma interpretação alternativa. Essa bibliografia ora enfatiza uma suposta guinada universalista na proteção social no país, engendrada pelos preceitos contidos na CF (KERSTENETZKY, 2012), ora um processo de liberalização, visível, por exemplo, na relação público/privado na saúde (VIANNA, 1998). A hipótese a ser defendida consiste na perspectiva de que essas duas tendências são simultâneas e não excludentes, partindo tanto de inovações institucionais da gestão do PT, como o Programa Bolsa Família (PBF), como de determinações constitucionais, como o Benefício de Prestação Continuada (BPC), além de serem influenciadas também por iniciativas anteriores, entre elas o fortalecimento do ramo privado de saúde realizado pela ditadura militar. Por fim, proponho que esses dois caminhos, comumente vistos como opostos, teriam, na verdade, complementaridades, como na articulação entre o PBF e o BPC no combate à extrema pobreza. Assim, se configuraria um welfare state dual caracterizado pela combinação e configuração de políticas sociais em torno de dois eixos principais: um privado/liberal e outro público/universal.

Para realizar esse trabalho, o caminho escolhido foi o da análise histórica, tendo como fontes tanto as referências bibliográficas, quanto documentos, principalmente os estatais, como leis, censos e estatísticas oficiais, disponíveis publicamente em bibliotecas e na internet. No intuito de melhor interpretar o percurso histórico das políticas sociais brasileiras, o primeiro capítulo da dissertação se concentra na discussão teórica em torno do conceito de welfare state e, mais especificamente, em torno do debate que versa sobre os regimes de welfare, no qual Esping-Andersen (1990) figura como referência central. O intuito dessa abordagem é desenvolver alguns marcos comparativos e analíticos para o estudo das tendências da seguridade social brasileira, enfatizando as características principais dos três modelos identificados pelo autor: o regime liberal ou anglo-saxão, o social-democrata ou escandinavo e o conservador-corporativo ou bismarckiano. 
A segunda parte do texto busca revisitar, por meio da literatura especializada e de alguns dados selecionados, a trajetória da proteção social brasileira de 1930 ao final da ditadura militar. Esforço grande para um espaço - e tempo - curto de estudo, esse capítulo aborda a temática de forma, evidentemente, abrangente, tendo como meta muito mais fazer uma narrativa que facilite a compreensão do período posterior, identificando determinadas tendências que vêm a influenciá-lo, do que propriamente constituir uma leitura completamente nova acerca da evolução do welfare state brasileiro no período. Nele, são enfatizados alguns aspectos, como o desenvolvimento do regime de saúde dual público/privado feito pela ditadura, que, conforme acredito, são importantes para a definição dos rumos das políticas sociais brasileiras após a CF de 1988.

Por fim, o terceiro capítulo aborda as transformações das políticas sociais brasileiras entre 1988 e 2016, tendo como foco de 2003 ao último ano do governo Dilma. Nele, são identificadas duas tendências principais que funcionaram como eixos na configuração do welfare state brasileiro no período: uma originária dos preceitos da $\mathrm{CF}$, marcada por uma ênfase na provisão pública e universal de serviços sociais e seguridade; a outra é caracterizada por políticas públicas focalizadas, de inspiração liberal, como o Programa Bolsa Família, e pela manutenção - e até mesmo reforço, no caso da educação superior - da provisão privada de serviços sociais, como se vê na continuidade da importância dos gastos privados em saúde. Esta segunda tendência é derivada de decisões políticas das gestões petistas e, também, do governo FHC, além de fruto de soluções de continuidade com relação a períodos anteriores, especialmente a ditadura militar. 


\section{História e regimes de welfare}

\subsection{Introdução}

O welfare state, como o conhecemos atualmente, é fruto de uma série de desenvolvimentos históricos de duração relativamente longa. Segundo Flora e Alber (1981), as últimas duas décadas do século XIX marcam o nascimento do Estado de bem-estar social. Nesse início, de acordo com Kuhle e Sander (2010), sua rede de proteção consiste basicamente em algumas políticas de seguridade social, cujo usufruto estava geralmente vinculado a algumas poucas categorias profissionais. Nas duas primeiras décadas do século XX, não há grandes mudanças no tipo de política social implementada, que segue muito focada em programas de seguridade.

Esse cenário, contudo, viria a mudar radicalmente após a Segunda Guerra Mundial. Nullmeier e Kaufmann (2010) afirmam que 1945 é o marco inicial de uma guinada vertical do desenvolvimento do welfare state na Europa ocidental. Nesse período, ganha corpo o que podemos chamar de virada universalista da política social, que consistiu em uma transformação qualitativa dos mecanismos de intervenção do Estado. Ao longo do final do século XIX e do começo do século XX, o sistema de proteção social era uma verdadeira colcha de retalhos que visava garantir alguma renda para trabalhadores vitimados por acidentes de trabalho, doenças e incapacitação; após 1945, contudo, essa configuração muda radicalmente, passando o bem-estar social a ser promovido para cada vez mais pessoas a partir de uma concepção universal, ao mesmo tempo que, até finais da década de 1950, a inovação institucional se manteve, somada à expansão da cobertura e dos benefícios.

Nesse contexto, tem início um período que a literatura costuma identificar como de franco crescimento dos Estados de bem-estar social ocidentais, que abrange, dependendo do tipo de periodização adotado, de 1945 ao início da década de 1970 ou 1980 (NULLMEIER e KAUFMANN, 2010). A esse período segue-se outro comumente identificado como de retração do welfare state, no qual, entretanto, podemos notar a manutenção de algumas das características dos chamados Golden Years do Estado social, como o gasto social como proporção do PIB, que permanece crescente. Nele, como apontam Nullmeier e Kaufmann (2010), há transformações qualitativas em políticas que apontam para uma maior residualização da proteção 
social, assim como a ascensão de políticas sociais que privilegiam mecanismos de mercado em detrimento à atuação universalista do Estado-provedor. Segundo Kerstenezky (2010), essa alteração pode ser considerada como uma das responsáveis pela perda de eficácia das políticas sociais e pelo consequente aumento da desigualdade nos países centrais nos últimos 30 anos.

É nesse percurso histórico que reside o foco desse capítulo. Meu objetivo é, desse modo, realizar uma breve discussão a respeito do desenvolvimento do welfare state europeu com base na literatura especializada. Após isso, introduzo o debate sobre os regimes de welfare, no qual a obra de Esping-Andersen (1990) tem lugar central e cuja exposição é essencial para o argumento a ser desenvolvido nesta dissertação.

\subsection{O percurso histórico dos welfare states europeus}

O Estado de bem-estar social é uma das principais construções políticoadministrativas do século XX. Foi ele, junto ao crescimento da economia capitalista, o responsável por estabelecer o elevado padrão de vida dos principais países capitalistas ao redor do mundo, transformando-os em sociedades de consumo de massa. Está, contudo, longe de representar uma ruptura radical com o passado: como Pierson e Leimgruber (2010) mostram, o welfare state nasce a partir de mudanças incrementais em formas de proteção social já existentes, em alguns casos, desde meados do século XVIII. Essas práticas - muitas vezes realizadas por instituições de caridade, além da também existente atuação estatal - eram focadas no alívio à pobreza, no cuidado aos idosos e na regulação do trabalho.

Muito mais do que uma criação intencionada e planejada do welfare state como um sistema amplo de proteção social, portanto, Pierson e Leimgruber (2010) argumentam a favor da ideia de que o que ocorreu foi, na verdade, uma evolução incremental e paulatina de programas e instituições, com aumentos gradativos na provisão, cobertura e orçamento dos programas. Simultaneamente, o Estado tomava o controle da oferta dessa rede de proteção, "roubando" o espaço de instituições de caridade, associações e até mesmo das famílias. Nesse sentido, Kerstenetzky (2012) aponta também que, conforme o Estado crescia em termos de provisão social, outras instituições que anteriormente eram as responsáveis por sua provisão diminuíam sua participação. Conforme veremos posteriormente, essa é a hipótese que Kuhnle e 
Sander (2010) levantam para tentar explicar o pioneirismo alemão perante a mais industrializada e democrática Grã-Bretanha.

Nesse início, porém, que vai de finais do século XIX à primeira década do século XX, uma das principais características do desenvolvimento do welfare state é seu caráter rastejante, marcado pelo "crescimento marginal de programas, cobertura e orçamentos" (PIERSON e LEIMGRUBER, 2010, p. 33). O elemento incremental, além disso, não se limita ao aspecto prático, sendo perceptível também na evolução da conceituação das políticas sociais, cujos policy makers buscavam apenas aliviar a situação de pobreza da classe trabalhadora, não engendrando a construção de um amplo sistema de proteção social de longa duração.

A despeito desse caráter marginal, Pierson e Leimgruber (2010) afirmam que o período de 1875 a 1914 é considerado como fundador do Estado de bem-estar social contemporâneo devido ao alto grau de inovação institucional que o marcou, somado a um crescimento consistente do gasto social com relação ao PIB. Nesse sentido, o país pioneiro foi o Império Alemão de Bismarck, cuja construção do Estado social se iniciou a partir da construção de uma legislação de seguridade social, com seguros contra doença (1883), acidentes (1884), invalidez e envelhecimento (1889). Segundo os autores, esse empreendimento se baseou em princípios já existentes na região em torno do papel social corporativo do Estado, de uma preocupação paternalista das elites dirigentes sobre as condições de vida da população e uma prática já antiga de apoio a trabalhadores através de uma infraestrutura de corporações ocupacionais.

Kuhle e Sander (2010) mostram ainda que a invenção alemã da seguridade social envolveu todo um novo papel para o Estado, que anteriormente tinha uma função muito mais de polícia e, a partir de então, passa a ter um papel ativo sobre a sociedade. Segundo os autores, a política social de Bismarck foi imposta de cima para baixo e tinha duas finalidades principais: 1) gerar adesão dos trabalhadores frente ao regime imperial e 2) contribuir para a construção do Estado-Nação alemão. O seguro social alemão, além disso, era controlado pelo Estado, dependia de contribuição e era compulsório, representando uma ruptura radical com os ideais liberais, muito em voga entre os policy makers da época.

Além disso, Esping-Andersen (1990), por sua vez, observa uma outra motivação para a criação da política social bismarckiana: gerar estratificações de 
classe entre os trabalhadores, minando a união do nascente movimento trabalhista alemão e incentivando a sua dependência do Estado. $O$ autor afirma ainda que o desenvolvimento de um setor privilegiado em termos de acesso à seguridade entre os trabalhadores do setor público também visava reforçar a ligação da população com o poder central, recompensando aqueles que se mantivessem atrelados ao regime.

Uma hipótese forte que Kuhnle e Sander (2010) levantam para tentar explicar o pioneirismo alemão frente à mais industrializada e democrática Inglaterra reside no fato de que, diferentemente do Reino Unido e suas colônias, a Alemanha não gozava de fontes alternativas de proteção social. Enquanto os ingleses contavam com uma miríade de sociedades voluntárias com ampla adesão dos trabalhadores que forneciam algum grau de segurança, o regime imperial alemão não dispunha de fontes alternativas de seguridade que amortecessem o impacto da industrialização sobre seu tecido social. Deste modo, a Alemanha teria tido uma urgência maior em construir um sistema de seguridade capitaneado e controlado pelo Estado (KUHNLE e SANDER, 2010).

Outra explicação possível é dada por Esping-Andersen (1990). Segundo o autor, a diferença entre o timing alemão e anglo-saxão deve-se a questões relativas à estrutura de classes de ambos os países. Nesse sentido, deve ser considerado que, nos países que primeiro desenvolveram mecanismos democráticos, como os EUA, o peso político-econômico dos pequenos proprietários rurais ainda era muito elevado. Assim, eles pressionavam pela queda dos impostos, não por seu aumento, necessário ao desenvolvimento de políticas sociais mais estruturadas. Já em países de regimes autoritários, como a França de Napoleão III ou a Alemanha de Bismarck, as classes altas teriam maior autonomia para aumentar impostos a despeito dos desejos da maioria da população (ESPING-ANDERSEN, 1990).

Segundo Pierson e Leimgruber (2010), o welfare state francês é comumente contrastado com o alemão. O conceito de État providence pode ser encontrado já em meados dos anos 1860, mas é somente próximo à virada do século XX que começa a ganhar contornos práticos mais reais em termos de política social. De acordo com os autores, o Estado social francês é tradicionalmente apresentado como sendo construído em torno das ideias de mutualité, solidarisme e subsidiarité. Por mutualité, devemos entender a ênfase em organizações voluntárias que buscam cuidar das necessidades de seus membros por meio da autogestão. Por solidariedade social ou 
solidarisme, devemos compreender o estímulo ao auxílio mútuo por meio da intervenção estatal. E, por fim, por subsidiarité, devemos tomar a ideia de que os seguros mútuos devem ser geridos por todas as partes envolvidas - os trabalhadores, os empregadores e o Estado -, porém, com alguma autonomia perante a administração central. Pierson e Leimgruber (2010) afirmam que, a partir desses três princípios, o sistema de seguridade francês que se desenvolveu é muitas vezes visto como descentralizado e, em certo sentido, oposto ao alemão fundado por Bismarck. Apesar desta visão, os autores argumentam que, assim como no caso do vizinho germânico, uma das principais preocupações dos policy makers era gerar aderência dos cidadãos ao Estado-Nação francês, contribuindo para a sua consolidação e recuperação após a derrota na guerra franco-prussiana.

O caso inglês é apontado por Kuhnle e Sander (2010) como de curioso atraso, dado seu maior desenvolvimento econômico e regime democrático. A hipótese que levantam a respeito da maior disponibilidade de fontes alternativas de bem-estar serve para lançar alguma luz sobre o tema, ainda que não o esgote. Segundo Pierson e Leimgruber (2010), na Grã-Bretanha - e também na Austrália e na Nova Zelândia, outros países pioneiros do welfare -, o surgimento do welfare state esteve muito ancorado nas ideias do social-liberalismo de T. H. Green, que advogava por uma equalização real de oportunidades para os indivíduos. Green acreditava que a função do Estado era assegurar as melhores condições possíveis para o florescimento humano. Isso deveria ser feito através da construção de políticas públicas que equalizassem as oportunidades de acesso a bens materiais e a oportunidades de vida, como educação, saúde e moradia, além do estabelecimento de uma taxação progressiva que buscasse dirimir as desigualdades resultantes do mecanismo de mercado.

A despeito da visão de Green, Kerstenezky (2012) aponta que o paradigma predominante na Grã-Bretanha do século XIX, que mantém-se forte nos primeiros anos do século XX, era de que a razão da miséria estava em falhas individuais dos pobres, devendo ser remediada por políticas focalizadas nos pobres meritórios, que são aqueles incapazes de trabalhar, e por mecanismos de repressão da mendicância e da chamada vadiagem. Esping-Andersen (1990) defende a hipótese de que a construção de welfare states ancorados em políticas de alívio da pobreza nos países anglo-saxãos teve o objetivo de criar dualismos que compelissem os indivíduos a 
competir no mercado de trabalho a qualquer custo. Isso porque, ao conceder benefícios monetários apenas para os muito pobres, esses Estados acabavam por criar um estigma em torno dos beneficiários, de modo que somente os muito desesperados iriam buscar recebe-lo.

A primeira mudança nesse paradigma surge com o Relatório da Minoria sobre as Leis dos Pobres (Minority Report on the Poor Laws), de Beatrice Webb, em 1909. Kerstenetzky (2012) afirma que esse documento identifica que a razão da pobreza possui fundamentos muito mais sociais que individuais, de modo que as poor laws estariam equivocadas, terminando por até mesmo piorar a situação dos pobres. Beveridge, posteriormente, em seu famoso relatório de 1942, considerado o marco da virada universalista do welfare state, reconheceria sua dívida perante esse trabalho pioneiro que, a despeito de sua inovação, é arquivado e mantém-se esquecido até 1942.

No que tange aos Estados Unidos, Pierson e Leimgruber (2010) afirmam que existe uma tendência da literatura em considerar o desenvolvimento do welfare state americano como retardatário e menos ambicioso. Isso ocorre porque, diferentemente do que aconteceu nos países europeus, não houve uma guinada para mecanismos universalistas de bem-estar capitaneados pela ação estatal ou foi sequer construído um sistema de tipo bismarckiano de regulação e proteção do mercado de trabalho. As tentativas que ocorreram foram residuais: segundo Skocpol (1995), houve uma tentativa de estabelecer um welfare state maternal por meio da atuação de mulheres profissionais, cujo objetivo principal era proteger as trabalhadoras femininas e seus filhos. Rodgers (1998), por sua vez, enfatiza um outro lado da história, afirmando que o projeto de bem-estar social nos EUA, ao longo do século XIX e início do XX, é muito ancorado nos desenvolvimentos europeus, especialmente o alemão. Nessa direção, Nullmeier e Kaufmann (2010) apontam que, se levarmos em consideração as políticas de proteção social baseadas no incentivo à atuação do mercado, os EUA despontam com uma relação do gasto social com relação ao PIB cuja evolução é semelhante àquela dos principais países europeus.

Além desses país centrais, outros menores e periféricos também foram pioneiros do Estado de bem-estar social, muitas vezes ultrapassando Alemanha, França, Reino Unido e EUA. São os casos da Suécia, da Austrália e da Nova Zelândia. 
Pierson e Leimgruber (2010) afirmam que o desenvolvimento do welfare state sueco se ancorou na noção de folkhemmer ou casa do povo do primeiro-ministro Per Albin Hansson, termo cunhado nos anos 1920. O termo aponta para a ideia da necessidade da construção de uma sociedade nacional que funcione como a casa de seus membros, onde todos podem viver e conviver a partir de critérios como equidade e respeito mútuo. A social-democracia sueca, que viria a dominar o cenário político de 1932 a 1976, defendia a estratégia de construir uma sociedade sem classes por meio da moderação da desigualdade social somada à provisão de serviços públicos de bem-estar para toda a população. A propriedade privada, nesse sentido, seria tolerada, mas seria acompanhada por uma taxação progressiva, por um elevado gasto social e por uma provisão social extensiva.

Para sustentar esse sistema, foi firmado um pacto político conhecido como o compromisso histórico dos social democratas com o capital sueco. Nesse acordo, o crescimento econômico capitalista seria estimulado e, ao mesmo tempo, seriam perseguidas políticas econômicas keynesianas de pleno emprego, com elevada taxação progressiva no intuito de dirimir as desigualdades geradas pelo mercado. Esse esquema foi tão bem sucedido que a Suécia, foi, segundo Kuhnle e Sander (2010), o primeiro país a construir um esquema universal e contributivo de aposentadorias e pensões para idosos. O mecanismo foi introduzido por um governo liberal em 1913, colocando a Suécia no mesmo nível que o Reino Unido em termos de cobertura da seguridade social antes da Primeira Guerra.

Segundo Kautto (2010), há ainda cinco peculiaridades históricas que imprimiram diferenciais na trajetória de desenvolvimento do welfare state sueco e nórdico como um todo: 1) a transferência precoce do papel de alívio da pobreza da Igreja para o Estado após a reforma luterana, que conferiu crescentes responsabilidades às municipalidades em cooperação direta com o poder central; 2) a importância política dos pequenos proprietários rurais, que cooperaram com os trabalhadores na formação de um pacto de classes e convergiram na direção de soluções universalistas, em detrimento a políticas sociais corporativos; 3) o prestígio e predomínio ganho pelos partidos social-democratas que, desde 1930, já implementavam políticas de seguridade muito mais abrangentes do que aquelas do modelo bismarckiano ou inglês; 4) o surgimento rápido de políticas sociais voltadas para mulheres e a grande presença de reformistas femininas, que conferiu uma 
posição privilegiada para os países nórdicos em termos de equidade de gênero; 5) um arcabouço histórico-cultural que enfatiza a busca por equidade, materializado politicamente no conceito de folkhemmer.

Na Austrália e na Nova Zelândia, por sua vez, cujas independências coincidem com o momento de nascimento do welfare state, as influências do social-liberalismo de T.H. Green também se fizeram sentir. De forma semelhante, Pierson e Leimgruber (2010) afirmam que ideais vitorianos a respeito do progresso social contribuíram, assim como no caso inglês, para o desenvolvimento de mecanismos de proteção social já nesses períodos iniciais. Assim, a legislação fabril e a regulação dos salários dessa ex-colônias britânicas estavam entre as mais avançadas do mundo, ao mesmo tempo que o Estado neozelandês já atuava, muito antes de Keynes, como empregador de última instância, equilibrando os choques no mercado de trabalho. Além disso, Kuhnle e Sander (2010) mostram que, no entre-guerras, a Nova Zelândia despontaria como uma das nações mais inovadoras no que tange à construção de políticas sociais, com inovações importantes em seguridade, como o primeiro sistema de pensão familiar do mundo. Em 1938, o Social Security Act promulgado pelo Labour Party neozelandês criou um sistema de bem-estar abrangente e unificado, considerado muito influente no desenvolvimento de outros esquemas similares ao redor do mundo.

A primeira grande transformação qualitativa dos welfare states europeus ocorre no pós-guerra com a virada universalista. Segundo Pierson e Leimgruber (2010), 1945 é tido por muitas interpretações como o ano que marca o surgimento do welfare state: e isso não é por um acaso. Em 1942, foi publicado o famoso Relatório Beveridge, tido como a base do Estado de bem-estar social universalista e inclusivo que veio a ser construído no pós-guerra. Autores posteriores, notavelmente T. H. Marshall, tiveram papel central na interpretação do welfare state. De acordo com Marshall (1964), a cidadania social, entendida como a obtenção dos direitos sociais por parte dos cidadãos, teria sido a última etapa em uma longa trajetória de obtenção de direitos por parte dos indivíduos, que começaria pelos direitos civis, passando pelos políticos e chegando, finalmente, aos sociais. É neste momento que o Estado converte-se em welfare state, na medida em que busca assegurar, a esses cidadãos, os direitos de que, então, passam a gozar.

No que tange ao debate político, no pós-1945 o welfare state converte-se na bandeira principal da social-democracia europeia. A trajetória para isso, como 
Przeworski (1985) analisou, vem a partir do abandono da expectativa da revolução comunista, passando pela ideia keynesiana de que não era mais necessário ter a posse direta dos meios de produção, mas somente induzir seus investimentos por meio de políticas macroeconômicas ativas. Isso, somado a uma complexa mistura de benefícios e impostos progressivos, teria, na visão dos social-democratas, condições de transformar de forma intensa os resultados distributivos da economia de mercado e “de-commodificar" variados aspectos da provisão social de recursos e oportunidades, gerando uma sociedade muito menos desigual e mais justa.

É a partir dessas bases que se firma, segundo Kerstenezky (2012), a estrutura que sustentará o período conhecido como os Golden Years do welfare state (19451973). Este intervalo é marcado por uma intensa inovação institucional, especialmente no imediato pós-guerra, seguido por grande crescimento do gasto social, com aumento da cobertura das políticas sociais, relaxamento dos critérios de concessão e ampliação do valor dos benefícios. Ao mesmo tempo, expande-se a atuação estatal no setor de serviços de saúde e educação, principalmente nos países nórdicos, enquanto no continente a seguridade se expande continuamente, abrangendo cada vez mais pessoas independentemente de vínculos empregatícios.

Nullmeier e Kaufman (2010) corroboram a importância de 1945 como marco, afirmando que deve ser considerado como o ponto de partida da Era de Ouro do welfare state. Considerando que os anos anteriores à Segunda Guerra Mundial foram de intensa inovação institucional no que tange à construção de sistemas de seguridade social, os autores se perguntam, porém, se não deveria ser esse período aquele considerado como de principal expansão do Estado social moderno.

Nesse sentido, afirmam que o ponto crucial do período pós-guerra reside na virada conceitual por qual passa a noção de welfare state. Assim, a ascensão da noção de direitos sociais, que T.H. Marshall (1964) analisa, vinculados à condição de cidadania, produz uma reconfiguração da distribuição de bem-estar, que deixa de estar majoritariamente atrelada a vínculos empregatícios e passa a ter um alcance universal - ou, ao menos, busca esse objetivo. Essa mudança pode ser chamada de virada universalista dos anos 1940. A construção dessas políticas universalistas ocorre, com maior intensidade, nos primeiros anos do pós-guerra, notavelmente nas décadas de 1940 e 1950. Trata-se, portanto, de um período de inovação institucional e, também, 
como já ressaltei, de expansão quantitativa - em termos de cobertura e benefícios - do welfare state.

Após esse período de inovação institucional dos anos 1945-1960, segue-se o de 1960-1973, caracterizado por uma expansão sem precedentes de benefícios e cobertura das políticas sociais. Há grande elevação do gasto social; esta, contudo, não é acompanhada por uma inovação institucional de larga escala, de modo que as bases do Estado social do período são aquelas desenvolvidas ao longo dos anos 1945-1960.

Para que esse período de 1945-1973 fosse marcado por essa expansão qualitativa e quantitativa do welfare state, segundo Nullmeier e Kaufman (2010), contribuíram também uma série de documentos e acordos internacionais, sendo o já citado Relatório Beveridge (1942) o marco inicial, seguido pela Declaração da Philadelphia (1944), da Organização Internacional do Trabalho (OIT) e, finalmente, pela Declaração Universal dos Direitos Humanos (1948). Dessas iniciativas, surgiu também a noção de Welfare Internationalism, segundo a qual a ordem internacional depende, também, das condições sociais internas aos países, representando outra quebra de paradigma em termos institucionais e conceituais.

Ocorre, porém, que transformações da economia política internacional e da correlação de forças internas dos países europeus levariam a uma alteração intensa nesse estado de coisas: com a ascensão do neoliberalismo, alguns dos principais sustentáculos da social-democracia europeia, como a mobilização sindical e o pacto interclasses, caem por terra. Dessa forma, segundo Nullmeier e Kaufmann (2010), ganha corpo um novo período, cuja principal característica foi a retração do Estado de bem-estar social europeu. Nele, os welfare states passam a enfrentar novos desafios causados, principalmente, pelos choques do petróleo (1973-1979), onde, inicialmente, tenta-se aplicar as soluções antigas, herdadas da Golden Age, aos novos problemas, sem muito sucesso. Entre 1980 e 1990, Taylor-Gooby (2002) afirma que ocorre um "interregno" no qual as políticas sociais teriam ficado muito imóveis e nebulosas frente às mudanças na conjuntura econômica e política internacional. Finalmente, na década de 1990, teríamos um outro subperíodo no qual a inovação institucional retorna, desta vez adaptando os Estados sociais aos problemas emergentes da crise fiscal, da globalização e do chamado capitalismo pós-industrial. 


\subsection{Regimes de welfare}

As periodizações que vimos refletem tendências históricas que impactam todos os welfare states de forma conjunta. Apesar disso, conforme Arts e Gelissen (2010) ressaltam, as respostas aos condicionamentos internacionais de ordem política e econômica variam substantivamente entre os diversos Estados sociais. Seguindo a abordagem dos recursos de poder - power resources approach -, Esping-Andersen (1990) afirma que essa variabilidade se dá por quatro motivos principais: 1) pelo balanço de poder entre as classes e principais grupos de interesse de uma dada sociedade; 2) pela natureza e níveis de mobilização de poder; 3) pela estruturação dos movimentos trabalhistas; 4) pelos padrões de formação de partidos e coalizões políticas.

A partir desses quatro fatores histórico-estruturais, se configuram uma série de diferentes modelos de welfare states, os chamados regimes de welfare, que EspingAndersen (1990) classifica em três tipos ideias principais: o continental ou conservador, marcado pela construção de uma rede de proteção atrelada a vínculos empregatícios e variável segundo as categorias profissionais, cujo maior exemplo seria a Alemanha; o liberal ou anglo-saxão, característico dos EUA e baseado, em larga medida, no bem-estar privado adquirido no mercado; e o nórdico ou socialdemocrata, no qual o welfare state atuaria principalmente por meio de esquemas de seguridade universais. Seu expoente principal seria a Suécia.

Esses regimes distintos engendrariam, cada um de uma forma, respostas particulares às transformações dos contextos político e econômico internacionais, de modo que criariam rotas distintas de desenvolvimento de seus welfare states. Esses caminhos, por sua vez, colaborariam para a construção de mecanismos de inércia, de forma que esses Estados sociais acabariam por criar uma certa dependência de trajetória, no sentido de que determinadas opções institucionais feitas no passado tendem a formar padrões que culminam em uma certa continuidade das políticas sociais.

O autor enfatiza, dessa forma, a importância da mobilização de recursos de poder para explicar o desenvolvimento dos diferentes tipos de Estados sociais. Diferentemente das abordagens anteriores, que enfocavam ou em fatores macroestruturais - como a abordagem da sociedade industrial, que via o surgimento 
do welfare state como uma consequência necessária da industrialização -, ou em fatores institucionais - a emergência da democracia tenderia a favorecer a construção de políticas sociais redistributivas, na medida em que a maioria do eleitorado se mobilizaria nesse sentido -, a base teórica de Esping-Andersen (1990) dá ênfase às coalizões de classes e à natureza das mobilizações de classe como fatores explicativos para as variações entre os regimes de welfare. Assim, nas palavras do autor:

A theory of welfare-state developments must clearly reconsider its causal assumptions if it wishes to explain clusters. The hope of finding one single powerful causal force must, be abandoned; the task is to identify salient interaction-effects. Based on the preceding arguments, three factors in particular should be of importance: the nature of class mobilization (especially of the working class); class-political coalition structures; and the historical legacy of regime institutionalization (ESPING-ANDERSEN, 1990, p. 29)

Outro ponto em que Esping-Andersen (1990) busca marcar posição frente à literatura anterior reside na questão metodológica. Segundo o autor, boa parte dos estudos comparativos sobre welfare states se apoiam nos gastos sociais/PIB como indicador principal de desempenho. Ocorre, porém, que o gasto social per se não pode ser considerado um indicador ideal da qualidade de um Estado de bem-estar. Isso ocorre porque a forma por meio da qual esse gasto é aplicado varia profundamente entre os welfare states. Desse modo, nos Estados de bem-estar liberais ou anglosaxãos, há um elevado gasto social, muitas vezes não contabilizado, no chamado welfare fiscal, caracterizado pela concessão de isenções fiscais para provedores privados de serviços como educação, saúde e aposentadoria. Também pode acontecer que, em um país com elevado desemprego devido a um descaso de seu welfare state com o pleno emprego, os gastos sociais disparem por conta do pagamento de seguros. Não se pode, portanto, argumenta Esping-Andersen (1990), utilizar o gasto social como indicador único, na medida em que um maior gasto social pode significar, na verdade, a realização de políticas que não necessariamente são as mais eficazes em termos de combate à desigualdade ou à commodificação dos indivíduos.

Para compreender e classificar os distintos tipos de welfare states, é crucial que sejam observadas, portanto, características qualitativas de suas políticas sociais e de sua formação histórica. Nessa direção, a atenção de Esping-Andersen (1990) se desloca para duas facetas principais: 1) a forma por meio da qual Estado, mercado e família se relacionam no fornecimento de bem-estar e 2) o grau de decommodificação 
promovido pelas políticas sociais. A seguir, veremos como cada uma delas influenciou o desenvolvimento históricos dos diferentes regimes de welfare.

A forma por meio da qual as instâncias do mercado, do Estado e da família se relacionam em termos de fornecimento de proteção social nos fornece informações centrais a respeito das características e do desenvolvimento histórico de um welfare state, de acordo com Esping-Andersen (1990). Assim, em países onde a ênfase na família tradicional é muito marcada, políticas públicas de igualdade de gênero no âmbito de trabalho, por exemplo, podem vir a ser escassas ou minadas no intuito de se preservar o lugar da mulher como dona de casa. Por outro lado, em sociedades onde o ideário liberal de não-interferência do Estado sobre o mercado é muito forte, reformas que busquem ampliar o papel do setor público no fornecimento de serviços como educação e saúde podem vir a enfrentar grande rejeição.

Por meio dessas categorias explicativas, Esping-Andersen (1990) dá continuidade à contribuição clássica de Titmuss (1958) relativa à diferenciação entre welfare states residuais e institucionais. Os primeiros atuam somente quando as duas outras grandes instâncias fornecedoras de bem-estar, o mercado e a família, falham; os segundos buscam garantir proteção social a todos os indivíduos independentemente da atuação das demais instâncias, se direcionando para toda a população e buscando criar garantias universalistas de bem-estar.

No período inicial de surgimento das políticas sociais, Esping-Andersen (1990) afirma que o posicionamento das classes rurais era central para a definição dos rumos dos diversos arranjos nacionais de seguridade. Assim, na Suécia, por exemplo, dado que a economia rural era baseada na pequena propriedade familiar, foi possível a formação da aliança red-green entre trabalhadores urbanos e rurais, de modo que esquemas universais de proteção social foram privilegiados, em detrimento a outros de tipo corporativista que tenderiam a favorecer mais determinadas categorias. $\mathrm{Na}$ Europa continental, por outro lado, a produção rural era altamente intensiva em trabalho e havia maior concentração da terra, gerando uma resistência das elites agrárias - que, como Gramsci mostra para a Itália, haviam capturado os trabalhadores rurais em sua coalização de classe - perante políticas de welfare que ampliassem os custos da mão de obra. 
As coalizões de classe e a estratificação social são, além disso, afetadas pelo próprio funcionamento do welfare state. É o que Esping-Andersen (1990) mostra ao estudar os efeitos dos diferentes regimes de welfare sobre suas respectivas sociedades. Assim, nos Estados sociais liberais, a atuação estatal direta na provisão de bem-estar resume-se às camadas mais pobres da população, que não têm condições de acessar os serviços superiores fornecidos pelo mercado, criando um dualismo entre aqueles que utilizam os serviços precários do Estado e aqueles que compram outros de melhor qualidade no mercado. Isso faz com que as classes médias sejam contrárias a empreitadas que busquem maior universalismo no fornecimento de políticas sociais, criando problemas de legitimidade para o welfare state. Nos regimes conservadores, por sua vez, a existência de uma série de benefícios cuja qualidade varia segundo a contribuição e à situação ocupacional faz com que o welfare state reforce a estratificação social já existente. Por fim, no caso dos sistemas social-democratas, o universalismo engendra uma diminuição das desigualdades sociais assim como ameniza a estratificação. Quando acompanhado pela criação de um tier de serviços públicos de qualidade superior que atendam os anseios da classe média ascendente, Esping-Andersen (1990) afirma que esses regimes tendem a mostrar resiliência, fazendo com que a classe média mantenha-se fiel ao fornecimento estatal de bemestar e disposta a pagar impostos para seu financiamento.

A decommodificação, por sua vez, também se relaciona intimamente com as diferentes trajetórias históricas dos welfare states. O conceito refere-se ao processo de autonomização dos indivíduos perante o mercado, garantindo-lhes meios para a manutenção de seu bem-estar a despeito de sua situação no mercado de trabalho. A decommodificação está diretamente vinculada à dimensão dos direitos sociais analisada por Marshall (1964): cada cidadão merece ter acesso a uma renda básica de sobrevivência a despeito de seu status de empregado, pois trata-se de um direito adquirido, semelhante a um direito político ou civil. Ademais, continua EspingAndersen (1990), quanto mais decommodificada é uma sociedade, menores serão os custos de cooperação por parte das diferentes categorias de trabalhadores, haja vista que todos terão acesso aos benefícios a despeito de suas situações diferenciadas.

Para compreendermos mais profundamente o conceito de decomodificação, contudo, devemos antes entender o de comodificação, que foi apresentado primeiramente por Polanyi (2013). Segundo o autor, a economia de mercado tende a 
transformar o trabalho dos indivíduos em uma mercadoria. Diferentemente dos sistemas produtivos anteriores, onde a sobrevivência das pessoas não estava diretamente vinculada à sua produção para o mercado, no capitalismo todo rendimento deve ser obtido a partir de uma venda, de modo que os trabalhadores se veem compelidos a negociarem a única mercadoria de que dispõem para sobreviver: sua força de trabalho. Ocorre, porém, que o trabalho é muito mais que simplesmente uma mercadoria: ele é a base da vida dos indivíduos, tanto em um nível subjetivo, quanto em um nível prático e material, no sentido de que seus rendimentos são essenciais para a sustentação das famílias. A tentativa de transformar esse trabalho, que é multidimensional e essencial para a condição humana, em uma mercadoria qualquer, consiste precisamente no processo de commodificação (POLANYI, 2013).

A decommodificação percebida por Esping-Andersen (1990) se relaciona, portanto, com a desconstrução do processo de commodificação; ou seja, trata-se de uma tendência que busca se opor a essa. Almeja, desse modo, autonomizar os indivíduos perante o mercado, conferindo-lhes formas de sobrevivência que permitam a eles ausentar-se do trabalho quando julgarem necessário, assim como sustentar-se em períodos de incapacidade ou descansar na velhice. Nas palavras do autor:

"To understand the concept, decommodification should not be confused with the complete eradication of labor as a commodity; it is not an issue of all or nothing. Rather, the concept refers to the degree to which individuals, or families, can uphold a socially acceptable standard of living independently of Market participation" (ESPING-ANDERSEN, 1990, p. 37).

Ademais, a decommodificação tem ainda um outro papel essencial: o de permitir a ação coletiva dos trabalhadores. Se o trabalho é completamente reduzido a uma mercadoria, todos os trabalhadores transformam-se, então, em meros ofertantes de trabalho que precisam constantemente competir entre si. Nesse cenário, analisa Esping-Andersen (1990), onde os indivíduos que deveriam estar cooperando estão, ao invés disso, competindo, a ação coletiva fica muito prejudicada, senão impossível. Por isso, a decommodificação tem um efeito não só socioeconômico ao melhorar a segurança e a qualidade de vida dos trabalhadores, mas também político, na medida em que facilita sua organização e ação enquanto classe.

Os diferentes regimes de welfare lidam - e lidaram ao longo de seu percurso histórico - de forma diferente com a questão da decommodificação. Segundo EspingAndersen (1990), as maneiras por meio das quais os Estados sociais enfrentaram o 
problema da commodificação foram centrais para a formação e consolidação de suas principais características. Assim, para compreendermos as variações entre os tipos de welfare states, devemos tentar traçar a forma por meio da qual cada um deles lidou com a temática.

Os Estados de bem-estar social caracterizados como conservadores ou corporativistas, como Alemanha, Áustria e França, gozam de uma longa tradição de seguridade social e associação de trabalhadores centrada em guildas e corporações. Têm em comum, além disso, uma forte influência do conservadorismo católico, que via nessas associações laborais formas de manter algum tipo de controle dos indivíduos para além dos mecanismos de mercado. Esping-Andersen (1990) conta que, ainda que de forma bastante diferente dos socialistas, o catolicismo conservador não via com bons olhos o fenômeno da commodificação massificada produzido pelo avanço da industrialização. Para suas lideranças, a revolução industrial, embora trouxesse progresso material, produzia uma desordem sem precedentes, não apenas por relegar uma série de trabalhadores e famílias à extrema pobreza sem qualquer emprego, mas também no aspecto moral e político. Para manter, desse modo, esses trabalhadores em seu lugar visto como ideal, isto é, como chefes de família e fiéis servidores do Estado, a solução encontrada foi estimular suas vinculações às corporações, que seriam vigiadas de forma próxima pelo poder central, conferindolhes incentivos. Posteriormente, quando os sindicatos passaram a se multiplicar, essa estrutura, que já estava de pé, foi estendida a eles sem maiores dificuldades, assim como serviram de base para a distribuição da seguridade social. Dessa forma, foram lançadas as bases do modelo que Esping-Andersen (1990) denomina conservador ou continental, que se tornaria o traço principal de welfare states como o alemão, o austríaco, o francês e o italiano.

No que tange às políticas sociais empreendidas por esses países a partir de 1945 e seus efeitos sobre a decomodificação, Esping-Andersen (1990) afirma que eles apresentam resultados intermediários: no ranking desenvolvido pelo autor, pontuam melhor que os países do cluster liberal em vários aspectos da seguridade social, como em aposentadorias, auxílio-doença e auxílio-desemprego, mas são pior ranqueados que os welfare states social-democratas da Escandinávia. Seus benefícios tendem a ser mais fartos que aqueles do modelo liberal, assim como suas condicionalidades e regras de eligibilidade menos rígidas, entretanto, seus sistemas de aposentadoria são 
fortemente atuariais e costumam apresentar taxas de reposição menores que as suecas, dinamarquesas ou norueguesas. Ao mesmo tempo, Arts e Gelissen (2010) ressaltam que suas características conservadoras e corporativas dificultam a emergência de políticas de gênero ou aquelas que facilitem, por exemplo, a conciliação famíliatrabalho, enquanto Esping-Andersen (1990) adiciona que seus benefícios permanecem muito vinculados ao vínculo empregatício.

A tradição liberal, que domina o pensamento social, político e econômico dos países anglo-saxãos, via os avanços do mercado e a comodificação de forma diametralmente oposta daquela dos conservadores católicos continentais. Sua perspectiva sobre eles era positiva, ao mesmo tempo que acreditava-se que qualquer interferência em seu funcionamento geraria muito mais efeitos negativos do que positivos. Embora a teoria de Smith concebesse lugar para a política pública e houvesse a ascensão de pensadores como T.H. Green, Esping-Andersen (1990) afirma que a tradição liberal de não-intervenção do Estado mantém-se vigorosa, especialmente nos EUA e na Austrália, onde até mesmo tentativas de estabelecer um salário mínimo eram vistas como contraproducentes do ponto de vista da lógica econômica - ao invés de diminuírem a pobreza, a aumentariam na medida em que tornariam o custo do trabalho mais elevado, diminuindo o emprego.

Isso não significa, afirma o autor, que não haja alternativas ao mercado na formação histórica dessa tradição. Elas existem e são até incentivadas, desde que sejam voluntárias ou associativas. Assim, desde o século XIX, uma série de iniciativas de assistência social, muitas vezes de cunho religioso, ganha corpo no Reino Unido, nos Estados Unidos e na Oceania. Quando o Estado, por sua vez, vê-se obrigado a atuar sobre a questão social, ele o faz por meio do desenvolvimento de políticas sociais recheadas de condicionalidades e com parcos benefícios, partindo do credo de que quantias mais vastas e uma cobertura mais generosa seriam um desincentivo ao trabalho. Na Grã-Bretanha, com o Relatório Beveridge (1942), há uma certa reversão nessa tendência, com o país despontando como o maior welfare state universalista no imediato pós-guerra. Com o passar dos anos, contudo, o liberalismo volta a influenciar fortemente o debate sobre a seguridade social na ilha, de forma que há a retomada de fortes traços liberais. Dessa forma, pode-se dizer, de acordo com Esping-Andersen (1990), que existe uma subdivisão dentro do cluster liberal: de um lado, o Reino Unido, onde o liberalismo, embora predominante, 
convive com um universalismo pujante e, do outro, os EUA e Austrália, e, em menor grau, a Nova Zelândia, nos quais a política social é extremamente orientada pela lógica dos "pobres meritórios" herdada do século XIX, e a seguridade é atuarial, de contribuição definida e, muitas vezes, com baixas taxas de reposição ${ }^{1}$.

A social-democracia e sua defesa do welfare state universalista são debitarias de uma tradição histórica que se inicia nos partidos comunistas revolucionários europeus e, aos poucos, converge para os partidos socialistas e de trabalhadores, que tornam-se defensores de políticas sociais que melhorem as condições de vida dos menos favorecidos. Przeworski (1985), em obra clássica, mostra como o debate políticoteórico deu-se entre as lideranças socialistas ao longo do século XX, partindo de um patamar onde questionava-se a validade de estratégias tidas como "melhoristas", até a formação do consenso em torno do welfare state. O autor afirma que a publicação da Teoria Geral de Keynes deu a esses partidos o instrumental que, combinado com sua visão universalista dos direitos sociais, configurou o cerne de sua atuação política e visão de mundo. Acreditava-se que, por meio do controle das principais variáveis macroeconômicas, o Estado poderia induzir os agentes privados da forma que julgasse necessária, promovendo o pleno emprego e uma maior equidade na distribuição de riqueza. Assim, não haveria mais a necessidade de se abolir a propriedade privada e obter o controle direto dos meios de produção para garantir a melhoria da qualidade de vida dos trabalhadores (PRZEWORSKI, 1985). Como vimos, a noção de folkhemmer exposta por Pierson e Leimgruber (2010), central na prática política da social-democracia sueca, se aproxima muito dessa lógica.

Inicialmente, porém, segundo Esping-Andersen (1990), os partidos socialistas não dispunham dos recursos necessários para empreender programas universalistas. Partindo de seu ideal de justiça social, suas primeiras políticas eram focados no alívio à pobreza daqueles mais necessitados e se aproximavam, nesse sentido, das políticas liberais. A partir do aumento de seu capital político e dos recursos financeiros do Estado, contudo, os social-democratas ampliam cada vez mais a cobertura e reduzem os critérios para o recebimento dos auxílios, buscando, ainda que com parcas rendas,

\footnotetext{
${ }^{1}$ Existe um debate em torno da validade da inclusão das nações da Oceania dentro do cluster liberal feita por Esping-Andersen (1990). Castles \& Mitchell (1993) e Castles (1998) argumentam que a Austrália e a Nova Zelândia possuem welfare states mais inclusivos que a média dos Estados liberais, enquanto, na tipologia desenvolvida por Korpi \& Palme (1998), as diferenças entre essas ex-colônias e o grupo anglo-saxão fica ainda mais acentuada.
} 
proteger o maior número possível de cidadãos. Esses valores seriam paulatinamente aumentados, especialmente nos países onde o projeto da social-democracia alcançou sua realização máxima, como na Súecia. Neles, explica Esping-Andersen (1990), a seguridade busca atender a todos, garantindo um mínimo social capaz de gerar autonomia dos indivíduos perante o mercado, ao mesmo tempo que uma ampla gama de serviços públicos de saúde e educação de altíssimo nível está disponível para os indivíduos. A decommodificação é, nesse sentido, o cerne desses welfare states, chegando até mesmo ao grau da desproletarização. Nas palavras do autor:

"In sum, the gist of de-commodification in the socialist paradigm is the emancipation from market dependency. It is in the quality and arrangement of social rights, not in their existence per se, that we can identify a distinct socialist approach. In contrast to the conservative models, dependence on family, morality, or authority is not the substitute for market dependence; the notion is rather that of individual independence. And, in contrast to liberalism, socialism's aim is to maximize and institutionalize rights. Where the fully developed socialist paradigm is pursued, it should, in' principle, facilitate a de-proletarianization of the worker's status: the worker's relationship to work will begin to approximate what privileged strata (such as the civil service) had enjoyed for decades and even centuries" (ESPING-ANDERSEN, 1990, p. 47).

Outra clivagem importante utilizada por Esping-Andersen (1990) e que merece ser vista com mais detalhes é aquela relativa à forma por meio da qual cada grupo de países lidava com a questão da estratificação social. Seus Estados de bem-estar promoveriam mais ou menos equidade? Buscariam manter distinções herdadas do passado, desigualdades distributivas geradas pela economia de mercado ou promover uma equalização geral da população? E como o fariam?

No caso dos Estados sociais conservadores, existe uma preocupação difundida com os efeitos simultâneos de nivelamento social e antagonismo de classes proporcionado pela economia de mercado, de modo que seus grupos dirigentes buscavam conter, de alguma forma, as mudanças vindouras. Assim, segundo o autor, a construção histórica das políticas sociais em países como Alemanha e Áustria objetivava, em larga medida, manter parte das hierarquias e privilégios herdados do passado, o que era visto como necessário à harmonia social por políticos e membros da alta hierarquia da Igreja Católica, cujo papel no reformismo social dessas nações foi central.

A estrutura que deu base à almejada distribuição desigual da seguridade foi a das corporações de ofício, herdada do Antigo Regime, de modo que os grupos de trabalhadores obtiveram benefícios distintos segundo suas funções. Isso engendrou 
um mecanismo no qual a estratificação social acabava por ser reproduzida pelo welfare state, na medida em que os diversos grupos ocupacionais tinham inserções distintas no que tange à seguridade e as profissões tradicionais e mais bem colocadas no mercado tinham acesso privilegiado aos benefícios. Ao mesmo tempo, EspingAndersen (1990) explica que Bismarck optou por enfatizar o estatismo quando desenvolveu seu sistema de seguridade, o que terminou por criar uma casta superior em termos de acesso ao Estado de bem-estar social: a dos funcionários públicos. Este grupo permanece, até os dias atuais, no caso dos países com uma tradição histórica conservadora-corporativa, como é o caso do Brasil, com um acesso muitíssimo diferenciado ao welfare state, que lhes confere uma série de benefícios de maior qualidade que os demais trabalhadores.

A força da Igreja Católica nas reformas sociais de países da Europa continental também mostrou-se central para o fortalecimento do modelo conservador-corporativo. Segundo Esping-Andersen (1990), papas enfatizaram, em diversas oportunidades como na encíclica Renum Novarum - a importância da combinação entre estatismo e corporativismo para a promoção do bem-estar social e manutenção da ordem. Dentro do pensamento eclesiástico, o sistema inaugurado por Bismarck e von Taeffe surgia como uma alternativa interessante, tanto à desarticulação social e destruição da tradição promovida pelo capitalismo, quanto à ameaça revolucionária do comunismo.

Nos regimes de welfare liberais ou anglo-saxãos, a perspectiva era diametralmente oposta àquela dos países conservadores: enquanto nestes buscava-se manter estruturas herdadas do Antigo Regime e utilizá-las para preservar a estratificação social em um novo contexto socioeconômico, naqueles, todos - ou quase todos - os resquícios pré-capitalistas eram vistos como impedimentos ao bom funcionamento do mercado e deveriam, portanto, ser varridos do mapa. Corporações, reciprocidade feudal, estruturas monárquicas: tudo deveria ser destruído no intuito de conceder ao mercado autorregulável o espaço necessário para atuar sem freios e, assim, produzir o ótimo social que levaria ao crescimento econômico e à melhoria da qualidade de vida das pessoas (ESPING-ANDERSEN, 1990). A partir de uma leitura radical da obra de Smith, o ideário liberal predominante em países como GrãBretanha, EUA e Austrália, ao menos até as duas primeiras décadas do século XX, não via com bons olhos a possibilidade de políticas sociais. Esping-Andersen (1990) afirma que, para muitos dos policy makers desses países, a ideia de um Estado 
interventor aparecia somente como algo que atrapalharia a eficiência do mercado autorregulado.

Inicialmente - de finais do século XIX ao início do $\mathrm{XX}$-, portanto, nos países de ideário marcadamente liberal, a pouca política social existente busca somente $\mathrm{o}$ alívio dos pobres e, além dela, temos apenas iniciativas de caridade ou associações cooperativas. Ocorre, porém, que a necessidade de construir uma política social mais ampla foi tornando-se cada vez mais evidente. A segunda revolução industrial não resolveu os problemas de miséria do proletariado e do dualismo existente nos países anglo-saxãos: de um lado, um grupo com acesso ao mercado, com funções bem remuneradas e capaz de adquirir seu bem-estar de forma privada e, do outro, um conjunto de trabalhadores sempre vulnerável às oscilações na demanda por trabalho, sem qualquer seguridade e, destarte, constantemente no limiar da miséria (ESPINGANDERSEN, 1990).

Tal percepção fará, segundo Esping-Andersen (1990), com que os policy makers do cluster liberal reconheçam a importância de se combinar mecanismos coletivos de seguridade social com a tradição em vigor do welfare privado adquirido no mercado. Assim, nasceria a forma por meio da qual esses países mantêm, com algumas variações, os seus Estados sociais até a atualidade: a existência de alguns programas públicos de seguridade social - geralmente intensamente atuariais e individuais - e transferência de renda condicionada, acompanhada por uma predominância do setor privado no fornecimento de serviços como saúde e educação, além do incentivo dado, por parte do Estado, à provisão privada de pensões e aposentadorias de qualidade superior para as classes médias e altas.

A consequência desse esquema, em termos de estratificação social, consiste, em larga medida, na reprodução das desigualdades de distribuição advindas do mercado (ESPING-ANDERSEN, 1990). As classes médias e altas buscam seu bem-estar no setor privado e têm, para isso, incentivos do Estado por meio do welfare fiscal ${ }^{2}$; as classes de trabalhadores cujos sindicatos são mais ativos e influentes gozam de um welfare ocupacional, especialmente na Austrália e na Nova Zelândia, onde os sindicatos são muito fortes e conseguem, assim, reajustes salariais que acabam por

\footnotetext{
${ }^{2}$ Por welfare fiscal devemos compreender a prática de se conceder incentivos fiscais para a provisão privada de seguridade e serviços como saúde e educação. O desconto no imposto de renda vigente no Brasil para gastos particulares com mensalidades escolares e consultas médicas são um exemplo desse instrumento.
} 
compensar a ausência de provisão pública de bem-estar; por fim, os mais pobres ficam dependentes de um welfare state altamente residual e frágil, cujo fornecimento de renda e seguridade é incapaz de garantir uma qualidade de vida próxima daquela gozada por aqueles que possuem um vínculo empregatício, ainda que evite a extrema pobreza.

No modelo social-democrata, os resultados são bastante distintos daqueles do cluster anglo-saxão. De acordo com Esping-Andersen (1990), esses regimes são aqueles que mais conseguem reverter a desigualdade gerada pela distribuição de recursos do mercado, relaxando as diferenças de classe e tornando a estratificação social muito mais amena. Nos países escandinavos, onde esse regime alcançou sua maior realização, foram formadas verdadeiras sociedades de classe média, onde não apenas o consumo é muito elevado, mas também a provisão pública e universal de bem-estar alcança níveis de qualidade altíssimos.

O autor afirma que um dos fatores que explicam esse diferencial está na predominância incomum dos partidos socialistas em países como Suécia, Noruega e Dinamarca. Partindo de sua visão universalista da revolução para libertação de todos os trabalhadores, as lideranças de esquerda desenvolveram um paradigma favorável à concepção de políticas sociais universalistas ${ }^{3}$, afastando tanto o problema do dualismo público-privado do modelo liberal, quanto dos múltiplos regimes de seguridade segundo as ocupações do cluster conservador-corporativo. Nas nações anglo-saxãs e continentais, os partidos socialistas ou de trabalhadores não gozaram jamais de um predomínio eleitoral como aquele de 40 anos do partido social-democrata sueco. Assim, embora quando chegassem ao poder tentassem empreender algumas mudanças na direção do universalismo, jamais conseguiram estabelecer welfare states tipicamente universais. Além disso, em países como EUA, Austrália e Nova Zelândia, Esping-Andersen (1990) ressalta que os movimentos trabalhistas estavam, muitas vezes, mais preocupados em obter vantagens particulares - como reajustes salariais do que, propriamente, em encampar uma luta determinada pelo universalismo das políticas sociais, incentivando o welfare ocupacional, ao invés do universalismo.

Feita a discussão a respeito dos efeitos dos regimes de welfare sobre a estratificação social de suas nações, estão expostas as principais características dos

\footnotetext{
${ }^{3}$ Para conhecer, com mais detalhes, o processo de construção histórica do paradigma social-democrata, ver Przeworski (1985).
} 
distintos clusters percebidos por Esping-Andersen (1990). Conforme ressaltam Nullmeier e Kaufmann (2010), a resiliência de The Three Worlds of Welfare Capitalism como um clássico no debate sobre o Estado de bem-estar social se deve, em boa parte, à ótima combinação entre o paradigma analítico de welfare state legitimacy ${ }^{4}$, que busca compreender como se formam e se sustentam os Estados sociais a partir de um ponto de vista qualitativo, e o método de análise quantitativa de dados de políticas sociais. Além disso, Arts e Gelissen (2010) argumentam que o livro, embora tenha recebido críticas ${ }^{5}$, funciona também como um marco temporal no debate sobre welfare state, separando um momento anterior, onde as análises eram quase que exclusivamente focadas na análise quantitativa da evolução dos gastos sociais, de um momento posterior, no qual outras variáveis de caráter qualitativo, como um estudo mais aprofundado do formato das políticas sociais, são incluídas no escopo analítico.

\subsection{Considerações finais}

Neste capítulo, vimos, de forma sintética, a trajetória histórica dos principais welfare states ocidentais. Observamos, assim, que a construção dos Estados de bemestar social pode ser dividida em quatro períodos principais: 1) um período inicial, de finais do século XIX à Primeira Guerra Mundial, marcado pelo desenvolvimento de políticas de seguridade social, no qual a Alemanha de Bismarck foi pioneira; 2) um momento posterior, o entre-guerras, no qual a inovação institucional continua, somada a alguma expansão da cobertura e redução nos critérios de eligibilidade; 3) uma terceira fase, de 1945 a 1972 conhecida como os Golden Years do welfare state, na qual uma série de documentos e iniciativas, cujo marco inicial é o Relatório Beveridge (1942), abre caminho para a virada universalista das políticas sociais, que se concretiza especialmente na Escandinávia; 4) um período de retração causado principalmente pela crise fiscal dos Estados e pelas modificações na economia

\footnotetext{
${ }^{4}$ Dentro desse escopo analítico da legitimidade social, existem trabalhos que mobilizam uma miríade de categorias para explicar o desenvolvimento dos Estados de bem-estar. Entre eles, Rieger \& Leibfried (2003) despontam como referências no debate sobre raízes culturais e religiosas dos welfare states.

${ }^{5}$ Para mais detalhes sobre as críticas recebidas por Esping-Andersen (1990), ver Arts \& Gelissen (2010). Uma das formulações complementares mais populares em torno da obra clássica do autor é aquela que define um quarto regime de welfare, que incluiria países como Itália, Portugal e Espanha. Cf. Ferrera (2010).
} 
política internacional, cuja ênfase sai da produção industrial e se desloca para o setor de serviços de alta qualificação.

Após essa introdução geral, apresentei, de maneira detalhada, a tipologia de Esping-Andersen (1990) que deu origem ao debate sobre regimes de welfare, cuja importância é central para a análise a ser feita nesta dissertação. Assim, mostrei como o autor divide os Estados de bem-estar social estudados em três tipos principais: o anglo-saxão ou liberal, o continental ou conservador, e o sueco ou social-democrata. O primeiro seria historicamente marcado pelo predomínio do mercado no fornecimento de welfare; o segundo, por um arranjo estatal-corporativo de viés conservador que privilegia a proteção de determinadas ocupações, especialmente dos funcionários públicos; o terceiro, pela presença predominante de esquemas universalistas de seguridade e fornecimento de serviços públicos de alta qualidade para toda a população.

A seguir, utilizarei esses três modelos de Estados de bem-estar social para auxiliar na interpretação da história das políticas sociais brasileiras, mostrando como o welfare state nacional apresenta uma trajetória variável em torno do modelo conservador-corporativo - que predomina até meados da ditadura militar -, e do liberal e social-democrata - que, conforme argumento, se desenvolvem e tornam-se centrais no período da Nova República. 


\section{O desenvolvimento histórico das políticas sociais brasileiras}

\subsection{Introdução}

O welfare state brasileiro, assim como os europeus, é fruto de um processo histórico de acumulação e transformação de uma miríade de políticas e práticas de proteção social. Sua trajetória, porém, é um pouco mais tortuosa, na medida em que, engendrado por um Estado dotado de muito menos recursos do que o alemão, francês ou inglês, termina por sofrer uma série de descontinuidades e revisões ao longo do tempo. Como veremos, seus regulamentos são menos ambiciosos e sua capacidade de fiscalizar sua aplicação prática pelos agentes privados é menor, de modo que, por exemplo, a legislação do salário mínimo instituída por Vargas é deturpada, sendo esse ordenado básico convertido, na verdade, em teto salarial para a maioria dos ramos industriais (CARDOSO, 2010).

O objetivo deste capítulo, contudo, não é realizar uma análise comparativa entre o desenvolvimento das políticas sociais brasileiras e europeias, muito menos cair na armadilha de construir uma "sociologia da falta" em torno de nossa histórica questão social. Trata-se, na verdade, de uma tentativa de reproduzir o debate travado pela literatura acerca da história da proteção social no Brasil, realizando, também, um exercício comparativo, porém, voltado para si. Dessa forma, busco comparar os distintos períodos entre si, quais sejam: o da Primeira República (1889-1930), o do Estado Novo (1930-1945), aquele da experiência democrática de 1946 a 1964 e, por fim, a ditadura civil-militar (1964-1985). Conforme aponta Kerstenetzky (2012), essa divisão segue não somente os marcos político-administrativos de transformação do nosso Estado-Nação, mas, também, momentos de inflexão das políticas sociais brasileiras que, dadas as transformações nos contextos sociopolíticos, experimentam, elas também, alterações importantes. Nesse estudo, ademais, veremos que as duas grandes ondas de desenvolvimento do welfare state brasileiro se dão em governos autoritários, sendo a primeira delas no regime varguista e a seguinte na ditadura militar.

Antes de entrar propriamente no corpo deste capítulo, gostaria, ainda, de fazer mais uma observação. É difícil para muitos estudiosos, mesmo aqueles das ciências 
sociais, conceber a ideia de um Estado de bem-estar social brasileiro. Segundo essa perspectiva, nossos mecanismos de proteção social seriam ainda, assim como nossa estrutura econômica, "subdesenvolvida" demais para falarmos em um welfare state nacional.

Ora, tomando as experiências europeias, especialmente os modelos socialdemocratas da Escandinávia, como parâmetro, é evidente que nossas políticas sociais aparecem como muito deficitárias em termos de abrangência e eficácia. Entretanto, quando olhamos para a nossa própria trajetória histórica e para a forma como algumas das instituições de proteção social impactaram a relação capital-trabalho, fica claro que, embora menos consistentes que as intervenções europeias, elas tiveram, no contexto nacional, consequências muito importantes. Além disso, a perspectiva aqui colocada contempla os welfare states não como objetos estanques, mas, sim, como continuums nos quais há distinções qualitativas e quantitivas, incluindo níveis de eficácia, abrangência, e modelos de intervenção distintos, como ressaltou EspingAndersen (1990).

Nessa perspectiva, adoto como marco inicial para o welfare state brasileiro o movimento de 1930 que levou Vargas ao poder e possibilitou, ao longo dos anos subsequentes, o desenvolvimento da legislação trabalhista e a expansão da seguridade social. Começo o capítulo discutindo o período da Primeira República, seguindo em ordem cronológica até o fim da ditadura civil-militar, no único intuito de conhecer melhor o percurso histórico de nossas políticas sociais e compreender como pode ter definido padrões que influenciem o funcionamento da proteção social brasileira até a contemporaneidade.

\subsection{Uma breve história das políticas sociais brasileiras da Primeira República à ditadura civil-militar}

Segundo Kerstenetzky (2012) o desenvolvimento histórico do regime de políticas sociais brasileiro se assemelha muito ao Europeu no que tange à ordem dos acontecimentos. Aqui, assim como na Alemanha de Bismarck, os primeiros esquemas de seguridade social foram para determinadas categorias funcionais com acesso privilegiado ao Estado, como militares e funcionários públicos. Os benefícios eram geralmente focados em manutenção de renda, com seguros contra doença, invalidez, viuvez etc. Em 1923, a lei Eloy Chaves introduziria a assistência médica, financiada e 
gerida por empregados e empregadores de cada empresa. Dez anos mais tarde a criação dos IAPs incluiria o Estado nesse processo.

Na Primeira República, a história das políticas sociais é mais marcada pela escassez de medidas do que por sua presença ${ }^{6}$. Primeiro, há o problema da incorporação dos ex-escravos ao mainstream da vida política e econômica brasileira, que ficou completamente fora da agenda pública. Em segundo lugar, a ausência quase total de tentativas de regulação da relação capital e trabalho na indústria, no comércio e no campo, além do problema da reforma agrária, deixaram marcas profundas que vão influenciar o lento desenvolvimento posterior do welfare state brasileiro (KERSTENETZKY, 2012).

Para explicar essa ausência de tentativas de regulação das questões socioeconômicas por parte do Estado, Santos (1979) argumenta que a ideologia do laissez-faire predominava entre as elites do período, impedindo a construção de saídas por meio das quais o setor público aumentasse sua intervenção na vida social. Vianna (1978), por outro lado, enfatiza que o liberalismo ortodoxo da elite agrárioexportadora, que ocupava o centro do poder ao longo da Primeira República, via de forma muito contrária qualquer tentativa de regulação estatal do processo de acumulação, ao mesmo tempo que os industriais em ascensão eram incapazes de sustentar uma legislação trabalhista que multiplicasse em demasia seus encargos.

Essa mesma ideologia, entretanto, deu lugar à promulgação do decreto-lei $\mathrm{n}^{\circ}$ 1.637, de 5 de janeiro de 1907 , que visava normatizar a sindicalização no país. O legislador, por meio desse texto, garantiu a livre filiação e desfiliação a sindicatos, bem como a livre criação dos mesmos, estabelecendo um cenário de ampla liberdade de associação sindical (BRASIL, 1907). Somada às ondas imigratórias que, então, ganhavam força no país e traziam com elas ideias comunistas e anarquistas, além da experiência sindical europeia, as manifestações sociais multiplicam-se, chegando a

\footnotetext{
${ }^{6}$ Por outro lado, pode se dizer que o Estado prestava, sim, certos benefícios sociais para a população; esse auxílio, porém, vinha informalmente a partir dos mecanismos próprios do pacto coronelista (LEAL, 2012). Embora seja difícil sustentar a hipótese de que os laços típicos do coronelismo engendravam um sistema efetivo de bem-estar social, acredito ser possível argumentar a favor da ideia de que, ainda que de maneira informal, reside no setor público a origem última dos benefícios pessoais concedidos por lideranças locais a sua clientela e que, portanto, essas benesses podem ser vistas como uma espécie de forma atabalhoada e compensatória de intervenção do Estado sobre a vida social. Essa hipótese, porém, necessita ainda de maior desenvolvimento, a ser realizado em outra oportunidade.
} 
107 greves operárias somente na capital de São Paulo entre 1917 e 1920 (SANTOS, 1979).

Santos (1979) argumenta que, seguindo um ideário estritamente liberal, os grupos dirigentes viam o papel do poder público na regulação da ordem socioeconômica como essencialmente passivo, sobrando, como alternativa, a ação repressiva frente aos grevistas. A notável ineficácia desse remédio, porém, irá fazer com que essas elites sintam a necessidade de atender, ainda que de forma insuficiente, parte das demandas colocadas. É assim que, na década de 1920, há algumas tentativas de construção de políticas de seguridade social (VIANNA, 1978), cujo caso mais emblemático foi a Lei Eloy-Chaves de 1923, que veremos adiante. No que tange à regulação do processo acumulativo, contudo, a escassez de iniciativas legislativas permanece, de modo que demandas como férias, regulação do trabalho infantil, entre outras que eram pautas constantes nas manifestações de trabalhadores, permanecem não atendidas (SANTOS, 1979).

Sobre as exceções, primeiro, em 1919 temos a promulgação do decreto número 3.274, de 15 de janeiro. Esta lei cria um seguro compulsório contra acidentes de trabalho, novidade na história brasileira, configurando uma notável inovação institucional no que tange à seguridade social no país. A partir dela, o legislador buscava garantir aos operários e seus dependentes o pagamento de uma indenização monetária em casos de morte ou incapacidade permanente ou temporária para o trabalho (BRASIL, 1919). Embora o valor das compensações fosse baixo - o máximo era o equivalente a três salários anuais, a ser pago de uma vez e somente em caso de morte - e a cobertura limitada - somente operários, isto é, trabalhadores formais ${ }^{7}$, essa instituição abriu caminho para inovações posteriores.

A Lei Eloy-Chaves, que já mencionamos, foi a principal delas, sendo considerada por muitos um marco de fundação das políticas sociais brasileiras (KERSTENETZKY, 2012). O decreto 4.682, de 24 de janeiro de 1923, estabelece a criação obrigatória de caixas de pensão e aposentadoria em todas as empresas ferroviárias do país. A lei estabelecia o pagamento de aposentadorias integrais equivalentes à média dos salários recebidos nos últimos 5 anos de serviço - para todos os empregados com 30 anos de trabalho e pelo menos 50 de idade, com

\footnotetext{
${ }^{7}$ Eram incluídos também os trabalhadores rurais, desde que operassem com motores "inanimados".
} 
desconto de $25 \%$ para aqueles que não tivessem ainda completado a idade mínima. Ademais, instituiu também o pagamento de pensões para dependentes em caso de morte do beneficiário, além de alterar dispositivos do decreto de acidentes de trabalho de 1919, determinando, por exemplo, o pagamento de aposentadoria integral para os dependentes de operário de empresa férrea morto em acidente de trabalho. Os fundos dessa caixa deveriam ser pagos pela empresa e pelos empregados - recolhimento mensal de $3 \%$ do ordenado -, sendo que a contribuição anual da empresa não poderia ser inferior àquela dos funcionários (BRASIL, 1923). Posteriormente, a Lei $\mathrm{n}^{\circ}$. 5.109/1926 estendeu o regime da Lei Eloy-Chaves aos portuários e marítimos, enquanto a Lei $\mathrm{n}^{\circ}$. 5.485/1928 incluiu os trabalhadores dos serviços telegráficos e radiotelegráficos, criando um verdadeiro sistema de caixas de aposentadoria e pensão (CAPs), no qual cada empresa e seus empregados constituía a sua própria CAP.

O golpe de 1930 e a subsequente ascensão de Vargas ao poder marcam uma inflexão nos direitos sociais no Brasil somada a esforços de industrialização e modernização da economia nacional. A partir dele, a seguridade social se expande paulatinamente, terminando por abranger todos os trabalhadores formais dos núcleos urbanos. Esse alargamento da cobertura segue, entretanto, a lógica dos modelos conservadores-corporativos europeus, ou seja, varia segundo as distintas categorias profissionais. Efetiva-se, a partir disso, um alargamento dos direitos sociais baseado na inserção via mercado de trabalho.

Vianna (1978) analisou esse processo de ascensão ao poder e posterior impulso modernizante engendrado pelo regime varguista, classificando-o como um tipo de modernização conservadora à brasileira. Esse impulso modernizante foi realizado pela elite agrária não-exportadora que, após alijar os antigos grupos agrário-exportadores do poder, que governavam durante a Primeira República, deu vasão à demanda reprimida por ampliação da ação Estatal, muito limitada pelo esquema liberal ortodoxo defendido pelos antigos oligarcas. $\mathrm{Na}$ aliança interclasses que derrubou a República Oligárquica, estados alijados do cerne do poder, como Pernambuco, Bahia e Rio de Janeiro, se juntaram, sob a liderança do Rio Grande do Sul, no intuito de derrotar o candidato paulista e fazer avançar reformas que ampliassem o escopo participativo do Estado brasileiro. Impedidos da vitória no processo eleitoral, recorreram a um movimento fora do aparato legal que, com o apoio decisivo de setores do movimento tenentista e das classes médias urbanas, chegou ao poder. 
Desde o começo, os discursos de Vargas e textos de lideranças e idealizadores do regime deixam clara sua intenção modernizante, tanto no sentido econômico, enfocando na necessidade de nacionalização de algumas indústrias essenciais, especialmente de produção de insumos industriais e energia, quanto no social, enfatizando a necessidade de atuação do Estado nos embates capital/trabalho, ao mesmo tempo que executava, de forma controlada, a ampliação da participação dos setores subalternos (VIANNA, 1978).

Vianna (1978) denomina o Estado que nasce dessa combinação entre aumento da intervenção econômica e social, somada à ampliação controlada da participação, de Estado benefactor. Suas iniciativas de proteção social se iniciam pela legislação trabalhista, que atendia à pauta dos movimentos sociais que atuavam desde a Primeira República, como a limitação da jornada de trabalho a oito horas, o repouso remunerado e a regulamentação do trabalho feminino (SANTOS, 1979). Somado a isso, o Decreto-Lei de 1938 cria a primeira tabela do salário mínimo, definindo-o como o valor que permite ao trabalhador atender a suas necessidades normais, tais como alimentação, vestuário e lazer. Além disso, define um reajuste trienal que visava, em larga medida, combater a perda de valor real dos ordenados. Ao longo dos governos Vargas, esse reajuste foi sempre realizado, algo que não se verificou posteriormente no governo Dutra (KERSTENETZKY, 2012).

A despeito disso, o salário mínimo manteve-se constantemente defasado em termos reais, e, pior ainda, dadas as dificuldades de fiscalização apresentadas pelo Ministério do Trabalho, ao invés de funcionar como piso da remuneração dos trabalhadores urbanos, converteu-se em teto salarial. Em 1960, por exemplo, 56\% dos trabalhadores urbanos ganhavam até um salário mínimo. Entre eles, 83\% dos trabalhadores das indústrias de transformação estavam nessa situação, assim como $91 \%$ dos operários da construção civil e $95 \%$ dos lotados em indústrias extrativas (CARDOSO, 2010). Em 1966, quando o salário mínimo tinha sofrido desvalorização real de $39 \%$ frente ao valor de $1959,53 \%$ do operariado brasileiro de carteira assinada ganhava menos que seu valor estipulado por lei. Assim, configurou-se o chamado efeito farol, quando, ao invés de uma base a partir da qual os salários devam ser definidos, o salário mínimo se transforma em um norte a ser perseguido, evidenciando as limitações da regulação trabalhista engendrada pelo Estado Novo. 
Esse quadro geral de baixa efetividade legislatória, porém, não muda o fato de que, pela primeira vez na história do Brasil, houve uma tentativa generalizada de posicionamento do Estado na regulação do conflito capital-trabalho. Nesse sentido, Santos (1979) argumenta que a revolução de 1930 promoveu uma renovação das elites dirigentes e, consequentemente, de seu aparato intelectual, possibilitando que novas soluções pudessem ser encontradas para a questão social. O espírito dessa intervenção é sintetizado pelo autor no conceito de cidadania regulada. Em suas palavras:

"Por cidadania regulada entendo o conceito de cidadania cujas raízes encontram-se, não em um código de valores políticos, mas em um sistema de estratificação ocupacional, e que, ademais, tal sistema de estratificação ocupacional é definido por norma legal. Em outras palavras, são cidadãos todos aqueles membros da comunidade que se encontram localizados em qualquer uma das ocupações reconhecidas e definidas por lei. A extensão da cidadania se faz, pois, via regulamentação de novas profissões e ocupações, em primeiro lugar, e mediante ampliação do escopo dos direitos associados a estas profissões, antes que por expansão dos valores inerentes ao conceito de membro da comunidade. A cidadania está embutida na profissão e os direitos do cidadãos restringem-se aos direitos do lugar que ocupa no processo produtivo, tal como reconhecido por lei" (SANTOS, 1979, p. 75).

Dessa forma, são cidadãos todos aqueles que ocupam profissões reconhecidas por lei. Sua certidão de nascimento, sua porta de entrada no plantel da cidadania, é a carteira de trabalho, instituída em 1932, de modo que a principal luta por parte das diferentes categorias profissionais é, em um primeiro momento, em torno da obtenção do reconhecimento estatal e, num segundo, focada na conquista de um melhor posicionamento hierárquico entre as profissões com vistas à obtenção de melhores benefícios e salários (SANTOS, 1979).

A cidadania regulada, ademais, deve ser vista como um processo fluido. Segundo Cardoso (2010), tal categoria não pode ser compreendida meramente como uma fronteira estanque que define quem é cidadão e quem não é. O projeto político do Estado Novo incentiva, em seus elementos estéticos, a perspectiva da possibilidade do acesso à cidadania. Para os brasileiros de então, tornar-se ou não um cidadão - isto é, obter uma carteira de trabalho - dependia de seus esforços individuais, na medida em que essa transformação existia como potência. Assim, o acesso aos benefícios sociais, por mais que fosse difícil, dada a complexidade e a ampla exigência de documentos e referências para obtenção da carteira de trabalho, aparecia como uma possibilidade constante, de forma que moldava expectativas e, portanto, influenciava a ação das classes trabalhadoras brasileiras, tanto a nível individual, quanto coletivo. Destarte, 
muito mais do que em uma demarcação fixa relativa ao status de cidadão, a cidadania regulada deve consiste em um continuum no qual há um gradiente em termos do acesso a direitos e ao reconhecimento político. Além disso, é possível que, dada as variações na demanda por mão de obra, trabalhadores migrem entre a cidadania e a não-cidadania constantemente, assim como variem, de forma menos intensa, sua categoria ao mudar de emprego ou posto de trabalho (CARDOSO, 2010).

Essa estrutura, embora crie um arranjo de políticas sociais capaz de dirimir algumas das desigualdades históricas da sociedade brasileira, contribuiu também para o arrefecimento dos movimentos sindicais contestatórios, especialmente o sindical. A moeda de troca da submissão dos sindicatos à tutela estatal não foi apenas a criação de uma legislação trabalhista, mas também a sua submissão à hegemonia da modernização conservadora. Nesse sentido, Vianna (1978) enfatiza a intervenção estatal sobre os sindicatos, que coopta e persegue as lideranças mais aguerridas, afastando a influência do Partido Comunista Brasileiro. Nesse intuito, insere uma rígida legislação, criando fiscalizações e certificações constantes que deveriam subsistir ao longo de toda a existência do sindicato, de sua criação à sua atuação posterior. Além disso, criou critérios para alijar os estrangeiros, que eram vistos como os portadores dos ideários mais radicais, da participação nos sindicatos, especialmente em cargos de liderança, criando uma espécie de política de "conteúdo nacional" que exigia uma cota superior de brasileiros (VIANNA, 1978).

A partir dessa engenharia político-institucional, repressiva e conservadora, por um lado, modernizante e abrangente, por outro, ganha força, portanto, uma espécie de welfare ocupacional no qual as diferentes categorias possuem rendimentos e garantias distintas dependendo da sua capacidade de influência dentro do sistema da cidadania regulada. Para sustentar esse esquema, a antiga lei de sindicalização de 1907, que garantia a liberdade sindical, precisava ser substituída. É assim que, já em 1931, o governo varguista institui a nova lei de sindicalização, que cria a unicidade sindical por categoria profissional e passa a exigir o registro dos sindicatos no Ministério do Trabalho (BRASIL, 1931). Obviamente, apenas os trabalhadores de ocupações reconhecidas por lei poderiam sindicalizar-se e somente eles poderiam gozar de alguns benefícios, como o direito de fazer reclamações trabalhistas e, segundo o decreto 23.768 de 1934, também só esses empregados teriam férias (BRASIL, 1934). 
Além da legislação trabalhista, o campo da seguridade também foi alvo de avanços por meio da criação dos Institutos de Aposentadoria e Pensão (IAPs), que têm governança e financiamento tripartite - Estado, empregadores e empregados. Os IAPs têm a função de realizar o pagamento de benefícios típicos da seguridade social, como aposentadorias por idade e por invalidez, pensão, auxílio-doença, entre outros, além de fornecerem também, em alguns casos, assistência médica e hospitalar a partir de uma rede própria. A vinculação ao IAP da categoria era obrigatória e a contribuição se dava por meio do regime de capitalização, de modo que maiores salários ao longo do período produtivo culminavam em benefícios superiores (VIANNA, 1998).

A partir dessa estrutura, os IAPs abrangem um guarda-chuva de riscos maior que o modelo engendrado pela lei Eloy-Chaves e, mais do que isso, fazem com que a responsabilidade pela proteção social dos indivíduos caminhe para o setor público. Anteriormente, a seguridade era financiada e gerida exclusivamente por trabalhadores e patrões, sem qualquer atuação direta do Estado. A partir da criação dos IAPs, isso muda, passando a adotar-se um esquema tripartite que influenciará fortemente o desenvolvimento de nossas políticas sociais (KERSTENETZKY, 2012).

Segundo Santos (1979), a criação dos IAPs, sendo o primeiro deles o IAPM, dos marítimos, promove um distanciamento do padrão da membership individual, característico dos CAPs, e faz a previdência caminhar em direção à uniformização dos benefícios segundo categorias profissionais, semelhante, portanto, ao regime conservador-corporativo. Essa engenharia irá, como já ressaltara Esping-Andersen (1990) no estudo de arranjos desse tipo na Europa, ter consequências de manutenção e até mesmo aprofundamento da estratificação social gerada no mercado que é, conforme vimos aqui, chancelada pelo Estado. Isso ocorre porque, ao vincular os benefícios de previdência às categorias ocupacionais e à contribuição pretérita, a lei acaba por reificar as desigualdades entre as distintas profissões, levando para as rendas de seguridade social as mesmas disparidades encontradas nos salários e que são, por sua vez, oriundas dos distintos recursos políticos que tais categorias e seus sindicatos são capazes de mobilizar (SANTOS, 1979).

Vianna (1998) apresenta argumento semelhante a Santos (1979), enfatizando, porém, algumas das virtudes dos IAPs, cuja oferta de serviços era bastante variada e, em alguns casos, de alta qualidade. Nesse sentido, quanto maior fosse a capacidade de 
mobilização da classe social, maior tendia a ser a variedade e o nível qualitativo dos serviços prestados pelo seu respectivo Instituto. O Instituto de Aposentadoria e Pensões dos Bancários (IAPB), criado em 1934, era um dos mais abastados, de modo que as rendas pagas por ele tendiam a ser maiores - também porque os ordenados de sua categoria eram mais elevados -, além de possuir uma melhor rede de atendimento hospitalar para os beneficiários. Outro instituto poderoso era o Instituto de Aposentadorias e Pensões dos Comerciários (IAPC), reformado em 1940, que fornecia, também, uma grande quantidade de benefícios para seus filiados. Um resumo dos benefícios e serviços prestados pelos diversos IAPs se encontra no quadro abaixo.

Tabela 1 - Benefícios oferecidos por IAPs selecionados nos anos 1940

\begin{tabular}{|c|c|c|c|c|}
\hline & $\begin{array}{c}\text { Instituto de } \\
\text { Aposentadoria } \\
\text { e Pensões dos } \\
\text { Marítimos } \\
\text { (IAPM) (1933) }\end{array}$ & $\begin{array}{l}\text { Instituto de } \\
\text { Aposentadoria } \\
\text { e Pensões } \\
\text { dos Bancários } \\
\text { (IAPB) (1934) }\end{array}$ & $\begin{array}{c}\text { Instituto de } \\
\text { Aposentadoria } \\
\text { e Pensões } \\
\text { dos } \\
\text { Industriários } \\
\text { (IAPI) (1938) }\end{array}$ & $\begin{array}{c}\text { Instituto de } \\
\text { Aposentadoria } \\
\text { e Pensões } \\
\text { dos } \\
\text { Comerciários } \\
\text { (IAPC) (1940) }\end{array}$ \\
\hline $\begin{array}{l}\text { Aposentadoria } \\
\text { (idade) }\end{array}$ & & $x$ & & (1... \\
\hline $\begin{array}{l}\text { Aposentadoria } \\
\quad \text { (invalidez) }\end{array}$ & $x$ & $x$ & $x$ & $x$ \\
\hline Pensão & $x$ & $x$ & $x$ & $x$ \\
\hline $\begin{array}{l}\text { Ass. Med. } \\
\text { Hosp. }\end{array}$ & $x$ & $x$ & & $x$ \\
\hline Aux. Farmac. & $x$ & $x$ & & \\
\hline $\begin{array}{c}\text { Aux. Funeral } \\
\text { Pecúlio }\end{array}$ & & $x$ & & $\begin{array}{l}x \\
x\end{array}$ \\
\hline Aux. Doença & & $x$ & $x$ & $x$ \\
\hline $\begin{array}{c}\text { Aux. Matern. } \\
\text { Aux. } \\
\text { Detenção }\end{array}$ & & $\begin{array}{l}x \\
x\end{array}$ & & $x$ \\
\hline
\end{tabular}

Fonte: Adaptado de Vianna (1998)

A partir do quadro acima, se pode confirmar aquilo que havia sido dito sobre o IAPB e o IAPC, sendo esses os dois institutos que apresentam a maior quantidade de benefícios. No outro extremo temos o IAPI, cuja oferta de serviços é bem menor e que, segundo Vianna (1998), tratava-se do instituto com maior número de beneficiários, equivalendo a mais ou menos a soma de todos os demais institutos juntos. Esse descompasso entre os diversos sistemas de seguridade materializa a estratificação percebida também por Santos (1979) e Kerstenetzky (2012), visto que os operários são membros do instituto menos desenvolvido, enquanto ocupações mais 
típicas da classe média, como a dos bancários, gozam de maiores benefícios. Assim, vemos novamente a já reiterada tendência de reprodução das desigualdades engendrada pelo esquema da cidadania regulada estadonovista.

A despeito desse aspecto, é necessário ressaltar que, diferente do que se verá posteriormente após a unificação dos IAPs sob a bandeira do INPS, o regime de previdência engendrado pelo Estado Novo era consideravelmente participativo. Essa participação ocorria de forma controlada e cerceada pela mão autoritária do governo, como ressalta Vianna (1978), mas existia, e a burocracia sindical, embora capturada pelas disputas de poder internas ao aparato conservador-corporativo, agia também como representante dos interesses de suas respectivas profissões (VIANNA, 1998). Os sindicalistas eram parte ativa nas negociações trabalhistas e, portanto, na regulação do conflito capital-trabalho, interagindo com as lideranças estatais e o empresariado de forma ativa. Trata-se, destarte, de um welfare state nos moldes bismarckianos, que, ademais, tinha uma tendência de expansão conforme eram reconhecidas novas categorias profissionais que, por sua vez, tinham seus sindicatos e seus IAPs criados. O lado perverso desse sistema vem do fato de que ele atrela a condição de cidadania não somente ao trabalho, mas a determinadas ocupações específicas, além de, no aspecto participativo, esvaziar a capacidade contestatória dos sindicatos ao atrelá-los ao Estado. Ao mesmo tempo, porém, provia determinados serviços para alguns grupos e promovia, ainda que de forma limitada, a elevação de uma série de indivíduos à condição de cidadania. Nesse processo, ele incentivava - e geria - toda uma luta coletiva - pela obtenção do reconhecimento profissional da categoria por parte do Estado - e individual - pela obtenção da carteira de trabalho - em torno do objetivo de tornar-se cidadão, influenciando fortemente não somente o andamento da modernização econômica e social, mas também o movimento de expansão da participação política.

No que tange à inovação institucional, o governo Vargas ficou marcado pela criação, em 1930, do Ministério da Educação e Saúde, apontando para o aumento da participação estatal no fornecimento de serviços - tendência que, contudo, realizou-se muito lentamente, a despeito da reforma Capanema, que focava principalmente na formação das elites. Em 1930 foi criado também o Ministério do Trabalho, Indústria e Comércio, responsável pela regulação e fiscalização da nascente legislação trabalhista. A Constituição de 1934, por sua vez, reitera muitos dos direitos e 
iniciativas recentemente conquistados. Em 1943, por fim, a CLT consolidará tais transformações em termos de regulação trabalhista e previdenciária.

A despeito desses avanços, Kerstenezky (2012) afirma que a realidade econômica brasileira era completamente diferente da alemã ou austríaca, o que criava consequências distintas para o regime de welfare adotado. Embora nesses países a inclusão via emprego favorecesse a manutenção da estratificação social, ela ainda alcançava boa parte da população. No Brasil, porém, havia uma gigantesca parcela da população que ficava completamente excluída da seguridade: os trabalhadores do setor informal que, nos anos 1930 e 1940, constituíam a maior parte da PEA urbana. Ao mesmo tempo, os trabalhadores rurais, em um país cuja maioria da população ainda vivia no campo, estavam também desprotegidos - cenário que muda somente na ditadura militar com a criação do FUNRURAL -, além de oprimidos em um regime de exploração baseado na grande propriedade.

A esse estado de coisas, herdado de períodos anteriores, somam-se as transformações engendradas pela rápida modernização industrial promovida por Vargas. Se, por um lado, a política de substituição de importações favorecia o desenvolvimento da indústria nacional e ampliava a riqueza do país, por outro ela engendrava uma série de transformações sobre o tecido social que, se deixadas de lado, gerariam uma miríade de consequências negativas. Além disso, a própria instituição dos direitos sociais exclusiva para os trabalhadores urbanos construiu um horizonte de perspectivas de ascensão social para os camponeses que, então, aceleram sua migração para as cidades em busca dos benefícios engendrados pelo trabalho protegido pela CLT (CARDOSO, 2010).

Assim, a urbanização intensa e desregulada, o crescimento populacional acelerado, as migrações internas, entre outros fenômenos característicos de um país em franco crescimento, contribuíram para o surgimento de uma série de demandas em termos de provisão de bem-estar, como saneamento básico, a construção de uma rede de saúde, o desenvolvimento de um sistema de educação capaz de preparar os jovens para o novo cenário econômico nacional etc. Tais necessidades, contudo, ressalta Kerstenezky (2012) não foram sistematicamente atendidas pelo regime varguista, ainda que suas lideranças tivessem consciência dos desafios estruturais herdados pelo regime, especialmente a questão rural e as possíveis consequências de uma migração maciça para as grandes cidades (CARDOSO, 2010). Sua intervenção, talvez mais por 
falta de recursos do que de vontade política, manteve-se quase que exclusivamente focada nos esquemas de seguridade regulados pelo vínculo empregatício.

Tal opção teria consequências de longo prazo para o desenvolvimento posterior do welfare state brasileiro. Seguindo a entrada teórica de Esping-Andersen (1990), Kerstenezky (2012) argumenta que o marco deixado por Vargas criaria um legado de difícil dissolução na história das políticas sociais brasileiras, cuja característica principal seria o viés corporativo de fornecimento de benefícios atrelados às categorias profissionais. Santos (1979) analisa que, ao instituir o esquema da cidadania regulada, Vargas engendrou também um grupo de forte influência política e altamente bem posicionado para defender seus interesses: a burocracia sindical. Essa classe, no que tange às disputas salariais realizadas pelos trabalhadores, se posicionava constantemente ao lado de seus representados; quando, porém, se via defronte a iniciativas que buscassem uma maior universalização da seguridade social, especialmente aquelas que afetavam o orçamento dos IAPs, essa burocracia mostravase altamente conservadora, sendo uma das principais fontes de resiliência do esquema da cidadania regulada. Foi assim que, ainda no próprio governo varguista, a tentativa de unificação da seguridade social sob um Instituto de Seguros Sociais impetrada no final do Estado Novo encontrou forte resistência, sendo, então, rejeitada.

Posteriormente, na experiência republicana de 46-64, a despeito da vigência do regime democrático, a inovação no que tange às políticas sociais seria muito inferior àquela do período varguista. A tendência é de manutenção da orientação conservadora-corporativa herdada do período anterior. Há, porém, algumas exceções, como a Lei Orgânica da Previdência, de 1960, que uniformizou os esquemas de previdência social e assistência médica, representando, segundo Santos (1979), o primeiro golpe desferido contra a cidadania regulada; a valorização real do salário mínimo, que estava defasado e contribuiu diretamente para a queda da desigualdade experimentada no período; e a promulgação do estatuto do Trabalhador Rural em 1963, que, assim como a reforma agrária, não foi efetivamente implementado (KERSTENETZKY, 2012).

A Lei Orgânica da Previdência foi criada por Juscelino Kubitschek e apontava na direção de um esquema previdenciário mais universalista, embora ainda de forma muito tênue. Instituído pela Lei n ${ }^{\circ} 3.807$, de 26 de agosto de 1960, o regime da LOPS preconizava uma aposentadoria compulsória para todos os trabalhadores formais 
urbanos financiado por contribuições mensais, além de um sistema de pensões para seus dependentes, unificando a legislação em torno dos IAPs. Trabalhadores rurais, domésticos e servidores civis e militares submetidos a regimes próprios de previdência ficavam excluídos da LOPS. Seu guarda-chuva de benefícios ia desde as tradicionais aposentadorias por velhice e invalidez a algumas inovações, como o auxílio natalidade e o auxílio reclusão. O valor do benefício era determinado pela média salarial dos últimos 12 meses de trabalho - superior, portanto, àquele preconizado pela Lei Eloy-Chaves. Não podia, além disso, ser inferior ao salário mínimo local - função de mínimo social do ordenado -, nem superior a cinco vezes o valor do salário mínimo nacional (BRASIL, 1960).

A Superintendência da Política Agrária (SUPRA) foi criada em 1962 com o objetivo de efetivar a reforma agrária. O plano de João Goulart era fazê-la sem indenizações monetárias, apenas com o pagamento de títulos da dívida agrária. Essa empreitada esteve incluída na sua luta política pelas chamadas reformas de base, que incluíam também, por exemplo, a valorização real do salário mínimo. Essa agenda encontrou forte resistência por parte de setores da política brasileira, sendo um dos estopins para o golpe de 1964.

Outras razões para o esgotamento da capacidade de gestão das questões socioeconômicas por parte do período da experiência democrática residem no fato de que o sistema da cidadania regulada, embora tenha sido eficiente no sentido de gerir recursos escassos no contexto autoritário do Estado Novo, carrega o fardo de não combater, de forma eficaz, as desigualdades geradas pela economia capitalista. A sua manutenção entre 1946 e 1964, portanto, conforme aponta Santos (1979) criará dificuldades para a capacidade de governo de Jânio Quadros e João Goulart. Isso será acentuado pelo contexto de início dos anos 1960, que demandava um esforço de engenharia institucional capaz de abarcar os novos conflitos sociais em crescente acirramento, demanda essa que a estrutura da cidadania regulada varguista não era capaz de contemplar e que, mesmo sob a presidência de Jango, o sistema político brasileiro não conseguiu atender. Dessa forma, surgiu a demanda por uma outra ruptura que, semelhante a 1930, deu-se também pela via autoritária, caindo, dessa vez, na mão dos governos militares (SANTOS, 1979).

O movimento de 1964 teve como uma de seus elementos principais, em termos de construção de hegemonia, a ênfase no nacionalismo em detrimento àquilo que era 
identificado como politicagem. No lugar da polarização política que marcou o final do governo Jango, Reis (1989) afirma que buscava-se colocar como ponto central do discurso do regime militar o enfoque na burocracia, enquanto esfera do técnico, no lugar do político, visto como um ambiente passível de influências vinculadas a interesses privados e contrárias, portanto, ao interesse nacional. Assim, se desenvolve um processo de esvaziamento do político, rompendo o período de expansão da participação característico da experiência republicana e substituindo-o por outro no qual defende-se a atuação da burocracia como solução real para os problemas de governo do Estado brasileiro. A consequente despolitização da vida social culmina também em um afastamento da tomada de decisões relativa ao policy making do debate na esfera pública, caminhando na direção de um modelo de desenvolvimento do welfare state ainda mais autoritário que o estadonovista (REIS, 1989). Nesse contexto, esse discurso tecnicista ganha corpo de modo a legitimar e diferenciar a ditadura militar dos regimes anteriores, formando o background político no qual irá se desdobrar a segunda grande onda de expansão das políticas sociais brasileiras.

Nesse sentido, na ditadura civil-militar posterior, Kerstenetzky (2012) afirma que temos outro momento de inflexão da política social brasileira, desta vez com uma guinada, ainda que precária, em direção ao universalismo. Algumas das principais iniciativas nesse sentido foram a unificação do sistema previdenciário e a construção de um esquema dual de saúde, com um segmento privado e um público - o primeiro reservado aos ricos, o segundo, de qualidade inferior, aos pobres -, ao lado do já existente modelo contributivo. Paralelamente, há um aumento grande da cobertura dos benefícios sociais, que não é, todavia, acompanhado por uma melhoria ou mesmo manutenção do grau de qualidade dos serviços. Configurar-se-ia, portanto, o que Kerstenetzky (2012) denominou de universalismo básico, um sistema no qual ocorre um alargamento da provisão de welfare sem que ele seja, contudo, acompanhado por uma evolução qualitativa das políticas sociais.

No aspecto econômico, os governos militares obtiveram sucesso em produzir um grande crescimento do PIB com inflação controlada, especialmente no período do milagre econômico (1969-1973). Esse desenvolvimento foi amplamente apoiado em uma forte política de substituição de importações, no qual o Brasil construiu um sistema industrial robusto e moderno, cuja finalização se dá no segundo PND, já no período de redução do crescimento (HERMANN, 2011). Tal processo de 
modernização industrial foi, contudo, apoiado na importação de máquinas e equipamentos, assim como de alguns insumos industriais principais, como petróleo e seus derivados, culminando em um acúmulo de déficits na balança de pagamentos brasileira. Com o choque de juros produzido pelo secretário do FED em 1979, Paul Volcker, a dívida brasileira - cujos empréstimos eram, em larga medida, pós-fixados e indexados à prime rate americana - dispara, gerando problemas crônicos de escassez de divisas e endividamento externo na economia nacional. Esse acontecimento também estaria na origem da espiral inflacionária que assolará o país até meados da década de 1990, dado o aumento do custo de vida provocado pela valorização do dólar causada pelo variação para cima da prime rate americana.

A despeito da notável elevação do nível de atividade econômica, esse crescimento não foi distribuído de forma equânime entre as diversas classes sociais. $\mathrm{O}$ que ocorreu, na verdade, foi o contrário disso: Draibe (2007) afirma que a opção dos governos militares por levar a cabo, especialmente durante o milagre, uma política de reajustes do salário mínimo abaixo da inflação ("subindexação" do salário mínimo) criou um problema de achatamento dos rendimentos da população mais pobre que, por sua vez, culminou em um crescimento sem precedentes da desigualdade brasileira.

Assim, há uma variação negativa - para cima, pois quanto mais próximo de 1 ou $100 \%$, mais desigual é a sociedade analisada - do índice de Gini no período, partindo de um patamar de $0,5^{8}$ e chegando ao nível de 0,62 em 1970. Esse padrão regressivo de distribuição de renda se refletiu nas transformações no padrão de consumo brasileiro no período, que se aproxima do nível europeu entre as camadas médias e altas, e mantém-se pouco diversificado entre as classes mais vulneráveis, cuja participação na distribuição do produto piora no período. Amenizando esse cenário, temos somente a queda proporcional do número de pobres ${ }^{9}$ no total da população, que vai de 67,9\% em 1970 para 39,47\% em 1980, variação essa que pode ser explicada pela expansão do emprego proporcionada pelo crescimento do período.

\footnotetext{
${ }^{8}$ Vale notar que esse patamar de 0,5 foi o menor das últimas cinco décadas, refletindo, principalmente, a política de valorização real do salário mínimo empreendida por Getúlio e Jango.

${ }^{9}$ Segundo o índice do IPEAData, pessoas pobres são aquelas que recebem rendimentos inferiores a $50 \%$ do salário mínimo em vigor em 1991.
} 
Apesar desse contexto de crescente desigualdade, o regime militar teve intensa atuação na seguridade social. O campo da previdência foi o de maior intervenção por parte desses governos. Em 1966, é criado o Instituto Nacional de Previdência Social (INPS) pelo decreto-lei número 72, que, pela primeira vez, unifica, de fato, os benefícios de seguridade existentes no Brasil, centralizando a administração de todos os IAPs. A exceção são os funcionários públicos civis e militares, que mantêm seus regimes próprios. Como consequência, ocorre um notável aumento da cobertura, alcançando, segundo o IPEA (2010), seis milhões de trabalhadores ativos em meados da década de 1960 - 50\% da PEA de então - e já chegando a oito milhões em 1970. Santos (1979) ressalta, contudo, que o caráter contributivo, que faz com que as remunerações pagas pelo fundo estejam vinculadas à contribuição individual pretérita, reduzem o elemento distributivo, enfatizando a manutenção da estratificação herdada do mercado. A evolução do número de benefícios pagos (aposentadorias e pensões) ao longo da primeira metade da década de 1970 pode ser vista no quadro abaixo, no qual 1971 é a base 100 de comparação

\begin{tabular}{c|c|c|c|c|c}
\hline \multicolumn{7}{c}{ Tabela 2 - Número de benefícios da Previdência por tipos } \\
\hline & 1971 & 1972 & 1973 & 1974 & 1975 \\
\hline Aposentadorias & 100 & 232 & 427 & 504 & 582 \\
\hline Invalidez & 100 & 1071 & 1157 & 1383 & 1647 \\
\hline Velhice & 100 & 107 & 716 & 853 & 1003 \\
\hline $\begin{array}{c}\text { Tempo de } \\
\text { serviço }\end{array}$ & 100 & 137 & 145 & 163 & 170 \\
\hline Abonos & 100 & 103 & 106 & 128 & 127 \\
\hline Pensões & 100 & 110 & 120 & 141 & 159 \\
\hline Auxílios & 100 & 106 & 123 & 117 & 114 \\
\hline
\end{tabular}

Fonte: Adaptado de Vianna (1998)

Para uma melhor visualização dos dados, segue o gráfico abaixo. 


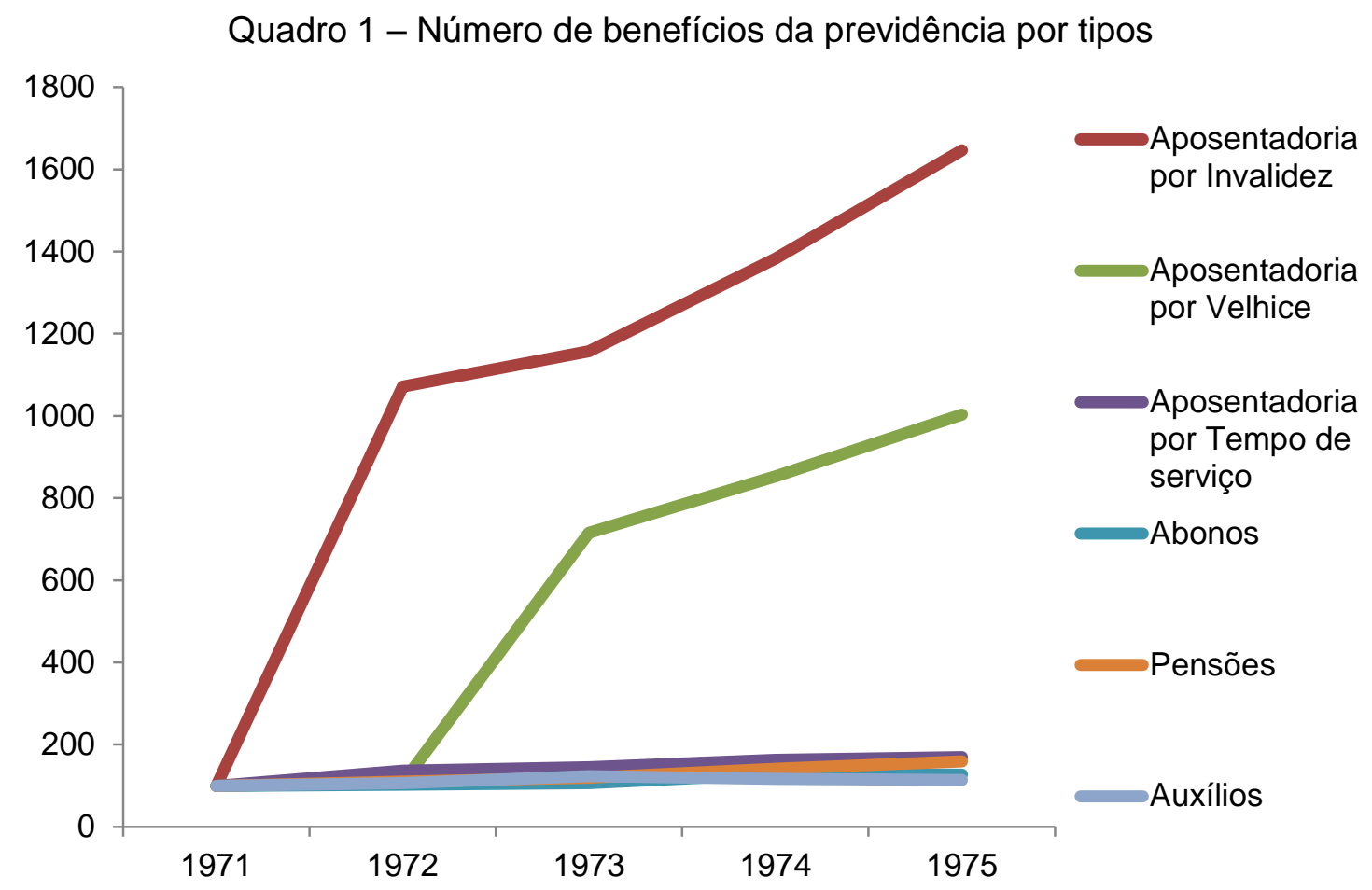

Fonte: Elaboração própria com base em dados de Vianna (1998)

Assim, se pode ver que há um crescimento em todos os benefícios pagos pela seguridade social ao longo da década de 1970, indicando um aumento considerável da cobertura. O crescimento mais notável, como era de se esperar, se dá nas aposentadorias por idade e por invalidez, consequências de uma sociedade em rápida urbanização e com estrutura demográfica em fase de maturação.

No que tange à gestão do INPS, embora tenha se mantido alguma participação dos empregadores e beneficiários na governança do sistema, o governo engendrou um regime em que poderia sempre conseguir a maioria no órgão diretor máximo do Instituto, o Departamento Nacional de Previdência Social (DNPS). Nele, o ConselhoDiretor era formado por oito integrantes, quatro deles indicados pelo Ministro de Estado e chancelados pela Presidência da República, dois representantes das empresas e dois dos empregados, sendo o presidente do Conselho obrigatoriamente um dos indicados pelo governo e gozando, também, do voto de desempate (BRASIL, 1966). Dessa forma, ainda que trabalhadores e empresariado fechassem questão em torno de alguma causa - o que já era difícil -, teriam muita dificuldade em aprová-la caso ela se opusesse aos planos da ditadura civil-militar.

No mais, a criação do INPS teve o objetivo de unificar o regime dos IAPs, mantendo os traços principais já definidos pela LOPS no que tange a valor dos 
benefícios e definição dos beneficiários do sistema (BRASIL, 1966). Posteriormente, em 1967, os benefícios relativos a acidentes de trabalho são incorporados pelo regime e, em 1972 e 1973, empregadas domésticas e trabalhadores autônomos transformamse em beneficiários da seguridade social. Em 1974, a licença-maternidade torna-se uma prestação da previdência social, ampliando seu alcance, e é instituída a Renda Mensal Vitalícia, que consistia em um pagamento de meio salário mínimo para idosos de 70 anos ou mais e inválidos pobres (KESTENETZKY, 2012). Trata-se, portanto, mais uma vez de uma incorporação precária a partir de benefícios e serviços dos mais básicos.

Na saúde, a unificação dos IAPs sob os auspícios do recém criado INPS teria consequências complexas. Por um lado, foi promovida uma intensa ampliação do acesso ao auxílio médico-hospitalar, pois os membros, por exemplo, do IAPI, passaram a ter acesso às redes do IAPB, IAPC e demais institutos. Por outro, essas redes, que forneciam atendimento de elevada qualidade para seus beneficiários, não foram capazes de suportar essa gigantesca e repentina expansão de demanda, culminando em filas gigantescas e hospitais lotados.

A resposta da ditadura civil-militar foi investir no desenvolvimento de dois novos ramos que viriam a somar-se ao contributivo: o privado, focado nas classes médias e altas, com elevada qualidade, e o público, altamente residual, cujo objetivo era atender aqueles excluídos do sistema por contribuição - basicamente, todos aqueles que não fossem trabalhadores formais urbanos - e também do nascente serviço particular. Segundo Vianna (1998), inicialmente, o governo financia diretamente o setor privado a partir do INPS que, dada a superlotação da rede contributiva, começa a comprar o serviço de hospitais privados, passando a ter uma série deles sob sua administração. Essa primeira fase dura de 1967 a 1975. O segundo momento gira em torno dos chamados convênios-empresa, quando o Estado incentiva e supervisiona a firmação de contratos entre corporações e prestadores privados de serviços médicos. Posteriormente, com o desenvolvimento de mecanismos típicos do welfare fiscal, passam a ser permitidas deduções pessoais dos impostos de renda a partir de gastos realizados em saúde, de modo que o Estado financia a provisão privada individual de forma indireta.

Algumas consequências podem ser tiradas desse processo. Primeiro, há uma tendência de privatização do sistema, sobre a qual falarei mais a seguir, denominada 
por Vianna (1998) americanização nefasta da seguridade social brasileira. Americanização porque, distante do modelo de Beveridge e cada vez afastando-se mais das ideias bismarckianas, a intervenção da ditadura militar sobre a previdência e, especialmente, sobre a saúde, incentivou um grande conjunto de pessoas a migrarem dos serviços públicos e contributivos para os privados, de maneira semelhante ao sistema americano, onde o Estado age muito mais como um fomentador da provisão privada de welfare do que como um provedor público de serviços. Perversa, contudo, porque não gozava nem da capacidade regulatória americana, que protege o consumidor e garante um fornecimento de qualidade mínima, nem da mesma divisão público-privada daquela: enquanto nos EUA a maioria dos cidadãos consome os serviços da rede privada, de melhor qualidade, no Brasil a maioria depende do sistema público que, por decisões político-administrativas tomadas inicialmente nos governos militares, apresenta qualidade inferior.

Apesar de tudo isso, vale dizer que, embora de forma precária, esse ativismo estatal no campo da saúde serviu para aumentar, de forma exponencial, o acesso a serviços desse tipo pela população brasileira, ainda que com um nível de qualidade e diversificação muito básico nos hospitais públicos (VIANNA, 1998).

Por outro lado, Santos (1979) afirma que as políticas mais redistributivas produzidas pela ditadura militar, no sentido de que rompem com o esquema da cidadania regulada e com a lógica de estratificação do modelo corporativoconservador, são o FUNRURAL e o Programa de Integração Social (PIS).

O FUNRURAL, criado em 1971, foi a primeira política pública capaz de iniciar a integração efetiva da área rural na economia de mercado (SANTOS, 1979). Após o fracasso do Estatuto do Trabalhador Rural de 1963, especialmente por problemas de financiamento, o FUNRURAL foi desenhado de modo a possuir um funcionamento minimamente eficaz. Nesse sentido, diferencia-se da previdência urbana em diversos aspectos: primeiro, os benefícios não estão vinculados à contribuição pretérita, de modo que os critérios elencados para o desígnio de que direitos serão recebidos são adversos à dimensão contratual característica do INPS; segundo, seu financiamento dá-se por impostos sobre a comercialização de produtos rurais e por tributação incidente sobre empresas urbanas; terceiro, não possui qualquer tipo de segmentação por profissão ou categoria ocupacional, de modo que todos os trabalhadores rurais são igualmente contemplados pelo fundo. 
Santos (1979) argumenta, então, que esse arranjo do FUNRURAL representa uma das maiores quebras com a lógica da cidadania regulada na história das políticas sociais brasileiras. Isso ocorre porque, ao rejeitar a divisão dos trabalhadores rurais em categorias ocupacionais e, ao mesmo tempo, desvincular a concessão de benefícios às contribuições passadas, o fundo acaba por romper simultaneamente com os aspectos corporativistas e, também, liberais do INPS, adotando uma postura universalista perante a questão da previdência rural. Além disso, o FUNRURAL contribui também para dirimir as desigualdades campo-cidade, na medida em que promove uma distribuição de renda dos meios urbanos, via coleta de impostos, em direção às áreas rurais, via pagamento de benefícios e fornecimento de serviços. Trata-se, portanto, de uma política pública que prima pela promoção da equidade, ao mesmo tempo que rompe com heranças negativas da trajetória histórica das políticas sociais brasileiras.

O PIS foi instituído pela lei $\mathrm{n}^{\circ} 7$ de 1970, tendo como objetivo promover a integração do empregado no desenvolvimento da empresa. Está vinculado a um debate histórico no Brasil em torno da necessidade de incluir os trabalhadores na participação dos lucros (SANTOS, 1979). Consiste em um fundo, dividido em contas individuais, que poderia ser sacado pelo trabalhador em determinadas situações, como casamento, invalidez, aposentadoria e aquisição da casa própria, a ser alimentado por contribuições da empresa baseadas em seu faturamento (BRASIL, 1970). Em 1975, o PIS é fundido com o PASEP, sofrendo algumas modificações. Perde, por exemplo, sua função de financiador habitacional, podendo, contudo, ser sacado anualmente, no valor de um salário mínimo, por trabalhadores que já estejam no programa há pelo menos 5 anos e que possuam renda mensal inferior a cinco salários mínimos regionais (BRASIL, 1975).

A remuneração da poupança do fundo é feita com base no desempenho global da economia, não das empresas individualmente, de modo que a dimensão da equidade é unificada àquela da acumulação de forma universalista. Ademais, o montante a que cada empregado tem direito é diretamente proporcional à quantidade de anos de trabalho e inversamente proporcional a seu montante salarial, invertendo a lógica corporativista de privilégio às profissões com maiores ordenados e mais bem colocadas na barganha política (SANTOS, 1979). Trata-se, portanto, de uma notável violação do regime da cidadania regulada, cujos efeitos, aliás, são ainda maiores, na 
medida em que, em 1974, lei complementar passa a dedicar recursos do fundo para os Planos de Desenvolvimento do BNDE (BRASIL, 1974).

Além do FUNRURAL e do PIS-PASEP, Santos (1979) afirma que o FGTS também foi instituído com uma lógica que buscava romper com o esquema da cidadania regulada. Seu objetivo era adequar a necessidade de proteção social dos trabalhadores com as demandas crescentes por maior flexibilidade na contratação de mão-de-obra colocadas pelo processo de acumulação. Assim, o fundo substituiu a estabilidade no emprego, representando uma quantia que o trabalhador poderia sacar em caso de demissão sem justa causa. Além disso, o FGTS também poderia ser retirado para obtenção da casa própria ou abertura de um negócio, o que asseguraria sua função distributiva. Ocorre, porém, que uma elevada rotatividade na mão de obra tornou essa sua última função subutilizada, convertendo-o em uma espécie de segurodesemprego. Comparado ao FUNRURAL e ao PIS-PASEP foi, deste modo, uma política menos eficaz.

O FGTS não ficou sozinho no rol das políticas sociais de sucesso questionável. Ao analisar a estrutura de desigualdade do país e a presença de determinados recursos básicos para a população, como rede de esgoto, escolarização, expectativa de vida etc., Santos (1979) conclui que o arranjo de bem-estar promovido pela ditadura civilmilitar ainda estava muito aquém do necessário para vencer os desafios colocados pela realidade brasileira. Pior do que isso: a sua opção por enfatizar o lado da seguridade social - que o autor denomina políticas compensatórias - deixa as áreas que mais impactam a transformação estrutural da sociedade - como saúde e educação ${ }^{10}$ - em segundo plano. Além disso, essa escolha engendra efeitos negativos para a própria capacidade de sustentação do sistema de previdência, pois, na medida em que o desenvolvimento econômico experimentado no período é concentrador de renda e não há investimento governamental maciço na formação de mão de obra qualificada, a provável queda da produtividade do trabalho no médio prazo criaria, como se verificou, uma situação de insolvência da previdência social. A saúde seria outro setor afetado, visto que a expansão do sistema, sem a injeção de recursos

\footnotetext{
${ }^{10}$ Santos (1979) mostra que, somados, de 1969 a 1973 os gastos da união com saúde, educação e cultura variaram em torno de 6 a 7\%. Entre 1950 e 1955, por exemplo, eles ficaram por volta de 10 a $12 \%$.
} 
financeiros e humanos adequada, levaria a uma situação de perca consistente da qualidade do atendimento.

No mais, o aumento da renda nacional e a expansão da classe média proporcionada pelo crescimento econômico promovido no milagre pecou por não enfrentar algumas desigualdades estruturais da organização socioeconômica brasileira. A questão racial, nesse sentido, mostra-se gritante, na medida em que a modernização autoritária realizada pelos militares terminou por não enfrentar - ou até mesmo ampliar -, em alguns aspectos - como no acesso à educação superior e, consequentemente, a rendas mais elevadas - as diferenças entre brancos e negros (SANTOS, 1979). Isso ocorreu porque, ao engendrar um processo rápido de industrialização sem fazer frente a esses desafios históricos do país, os indivíduos que gozavam de um posicionamento privilegiado em termos de raça e gênero tiveram maior facilidade de tomar parte dos benefícios da elevação da atividade econômica, obtendo empregos nos setores mais dinâmicos. Por outro lado, grupos historicamente marginalizados mantiveram-se em posições subalternas, principalmente relegados a trabalhos informais no meio urbano.

Em suma, pode-se afirmar que a ditadura civil-militar no Brasil, embora tenha produzido alguns avanços na direção da universalização das políticas sociais, manteve o valor dos benefícios e a qualidade dos serviços ainda em patamares muito baixos, além de engendrar uma guinada privatista no campo da saúde. Está, portanto, muito distante do modelo social-democrata preconizado por Esping-Andersen (1990), baseado em benefícios generosos e na provisão de serviços públicos de saúde e educação de padrões elevados.

Dessa forma, embora seja possível enfatizar a virada universalista do welfare state nesse período, acredito que é necessário ter atenção também para outro de seus aspectos: o incentivo à ampliação da provisão privada de bem-estar por meio do financiamento público indireto. O welfare fiscal surge nesse período no Brasil, constituindo, portanto, uma inovação do regime militar no cenário nacional. Essa engenharia social incentiva a fuga das classes médias - estas, também, multiplicadas pelo desenvolvimento econômico engendrado no mesmo período - para o nascente regime de saúde privado, também este incentivado pela ditadura civil-militar. Consiste, além disso, em uma opção de política pública altamente regressiva, pois financia a compra de serviços particulares pelos setores mais abastados da população. 
Dada a estrutura tributária brasileira do período majoritariamente baseada em impostos indiretos, pode-se dizer que os governos militares foram responsáveis por desenvolver um sistema onde o consumo dos mais pobres sustenta o acesso dos mais ricos a serviços de bem-estar social. Se assemelha, nesse sentido, às características dos regimes de welfare liberais, caracterizados pela existência de políticas de welfare fiscal, ocupacional e pelo estímulo estatal à provisão privada de serviços sociais, principalmente saúde e educação superior.

Outra limitação da frágil expansão universalizante engendrada pela ditadura militar é derivada da permanência da forte presença do setor informal na ocupação da PEA, que permanece descoberto pela seguridade social. Carleial e Malaguti (2001), estimam que a proporção de trabalhadores na informalidade no período do milagre econômico deve ter ficado em torno de $40 \%$, representando, portanto, uma grande parte da população na precariedade, com acesso limitado à seguridade e, muitas vezes, sequer recebendo qualquer tipo de assistência social. Nesse aspecto, a experiência brasileira se assemelha ao regime mediterrâneo analisado por Ferrera (2010), onde os trabalhadores informais também constituem parte considerável da população e a provisão de bem-estar depende, em larga medida, de laços afetivos, principalmente familiares, que são, então, somados a benefícios - muitas vezes parcos - pagos pela seguridade social e a rendimentos obtidos no mercado.

Assim, acredito ser necessário analisar o período histórico de 1964-1985 não somente como um momento embrionário ou precursor da virada universalista posterior proporcionada pela Constituição de 1988, mas também como um período de visível inovação institucional - ao menos no que concerne à história das políticas sociais brasileiras - na direção de uma provisão de bem-estar de inspiração anglosaxã. Conforme analisarei no capítulo seguinte, essa tendência ao privatismo, embora não diretamente endossada pela CF de 1988, se fortaleceria ao longo do período da Nova República, inclusive nos governos petistas, nos quais uma série de políticas sociais de inspiração liberal tornariam-se nomes conhecidos da população, como o programa Bolsa Família, o ProUni e o FIES. Assim como no período da ditadura, contudo, ela conviveria também com esforços em direção ao universalismo, como a ampliação da provisão pública de serviços de educação superior e uma política de valorização real do salário mínimo, que recupera, especialmente nos governos Lula e Dilma, seu papel de indexador social. 
Por fim, considero importante, ainda, sintetizar os pontos expostos, bem como realizar algumas comparações que ajudarão a ilustrar o argumento a ser seguido no próximo capítulo. Nesse sentido, é necessário considerar que, no período anterior à CF de 1988, os dois grandes momentos de expansão das políticas sociais brasileiras se deram sob regimes autoritários. Enquanto na Primeira República - cujas características democráticas são, aliás, bastante questionáveis - a inovação em termos de seguridade social foi bastante escassa, e na experiência democrática de 1946-1964 os avanços foram poucos e se deram a partir de muitos embates, o Estado Novo e a ditadura civil-militar conseguiram, de formas bastante distintas e com naturezas divergentes, avançar agendas de reforma social consideravelmente amplas.

A revolução de 1930 engendrou um regime ditatorial sui generis. Sui generis porque, conforme apontam Santos (1979), Vianna (1978) e Vianna (1998), ele não visava extinguir a capacidade participativa dos brasileiros, mas, sim, canalizá-la dentro de parâmetros considerados adequados de tipo conservador-corporativo. Isso foi feito por meio do esquema amplamente controlado pelo Estado - e muitas vezes repressivo - da cidadania regulada. Esquema esse, conforme esclarece Vianna (1978), engendrado a partir de uma ação reformadora liderada pelo setor agrário nãoexportador, que deslocou a elite rural voltada para o mercado externo do centro do poder e, atendendo também aos interesses da burguesia industrial em ascensão, desenvolveu o processo de modernização conservadora característico do regime getulista. Assim, diferentemente do regime militar, no qual pode se perceber uma cidadania em suspenso (SANTOS, 1979), característica de um governo que tentava forçar a despolitização da vida social (REIS, 1989), no período estadonovista temos uma participação crescente dos trabalhadores por meio de seus sindicatos, que possuem interferência direta a nível de governo e gerem os IAPs de suas respectivas categorias. Têm, portanto, recursos políticos e financeiros relevantes, sendo atores cruciais dentro do jogo de poder da cidadania regulada, embora, ao serem incluídos no processo de cidadania a partir de uma atuação "por cima" do Estado, suas principais lideranças acabem sendo cooptadas ou perseguidas, de modo a domesticar os sindicatos e fazê-los aderir ao projeto estatal (VIANNA, 1978).

O regime militar, de maneira distinta, buscou eliminar a participação popular, seja por via direta, seja via burocracia sindical. Como mostra Vianna (1998), a criação do INPS acabou com a gerência dos sindicatos sobre os IAPs, colocando-os sob 
domínio total do Estado. Os movimentos sociais em geral e os sindicatos, em particular, foram violentamente reprimidos, tornando muito difícil que barganhassem por melhores condições de trabalho ou mesmo benefícios minimamente mais generosos. Assim, de um esquema de cidadania regulada, o país foi reduzido a uma situação de não-cidadania, na qual uma república meramente formal servia somente para legitimar as ações dos presidentes autocratas. Nesse escopo, a política de subindexação do salário mínimo teve espaço para correr livre, ao mesmo tempo que a construção privatista na saúde pôde realizar-se sem qualquer resistência mais relevante. A tendência universalista identificada por Kerstenetzky (2012) é, todavia, verdadeira, e se materializa especialmente em políticas como o FUNRURAL, mas convive com uma guinada privatista igualmente forte e intimamente vinculada ao projeto militar mais geral de expansão do capitalismo no Brasil. Faz-se necessário, destarte, analisar e considerar esses dois vetores da reforma social produzida pelos militares, buscando compreender de que formas eles criaram dependências da trajetória que afetam, até os dias atuais, os nossos mecanismos de promoção de bemestar.

\subsection{Considerações finais}

A trajetória das políticas sociais brasileiras tem uma série de peculiaridades que busquei ressaltar aqui. De início, é notável que, em nosso primeiro período republicano, a inovação institucional em termos de mecanismos de bem-estar tenha sido bastante reduzida. A principal exceção no período foi a Lei Eloy-Chaves, de 1923, que engendrou a criação de caixas de aposentadoria e pensão para os ferroviários, a serem instituídas e financiadas por cada empresa e seus empregados. Posteriormente, com a agregação de outras leis ainda no período da Primeira República, essas caixas seriam estendidas para outras categorias, como os funcionários de serviços telegráficos, configurando um verdadeiro sistema de seguridade em torno das CAPs. Esse esquema era altamente fragmentado, na medida em que, além de ser baseado em categorias funcionais e depender de contribuições individuais, variava de empresa para empresa.

Tal estado de coisas viria a ser alterado com o golpe de 1930 e a ascensão do regime do Estado Novo, quando é montado o sistema da cidadania regulada. Nesta organização, os benefícios sociais são transformados em direitos atrelados ao vínculo empregatício; são, portanto, direitos do trabalho reconhecido por lei. A partir dela, há 
uma notável expansão da seguridade social, além de ser criada a legislação trabalhista. O arranjo institucional que ficou responsável por garantir os benefícios de aposentadoria, pensões, seguros, além de assistência médica, foi o dos Institutos de Aposentadoria e Pensão que, mantendo a segregação por categorias funcionais das CAPs, acabava, entretanto, com a divisão por empresas, reunindo todos os empregados de uma determinada ocupação sob a égide do mesmo Instituto. Além disso, o Estado passa a lidar diretamente com sua direção em um esquema tripartite de governança, no qual empregados e empregadores também eram representados. As limitações desse modelo, como vimos, residem em sua incapacidade de expandir de forma universal o acesso aos direitos sociais, bem como na estratificação social que ele reproduz e, em certo sentido, aprofunda.

Essas dificuldades, embora existentes desde o período do Estado Novo, se tornaram mais evidentes durante a experiência republicana de 1946 a 1964, quando, a partir de uma radicalização dos conflitos sociais que a cidadania regulada não conseguiu abarcar, torna-se realidade o golpe militar de 1964. A ditadura civil-militar que se seguiu foi dura na repressão aos sindicatos e movimentos sociais em geral, afastando a participação dos empregados da gestão dos IAPs que, em 1966, tiveram sua gestão unificada sob a égide do Instituto Nacional de Seguridade Social. Tal unificação, inédita na história brasileira, teve como virtude ampliar, de forma notável, o número de beneficiários da seguridade social, caminhando em direção a um modelo mais universalista de acesso a direitos. Por outro lado, porém, essa universalização incipiente se deu a um nível de qualidade muito baixo, fazendo com que, inclusive, sistemas de saúde funcionais, como aquele do IAPB, sofressem uma explosão de demanda que deteriorou suas condições de funcionamento. Outras rupturas engendradas pelo regime militar frente ao esquema da cidadania regulada podem ser encontradas também na criação do FUNRURAL, cujos benefícios eram desvinculados da contribuição passada e o financiamento era feito por meio de impostos, além do PIS-PASEP.

No que concerne mais diretamente o argumento a ser sustentado aqui, a principal inovação da ditadura civil-militar se deu no campo da saúde a partir da fomentação de um sistema híbrido público-privado. Conforme acredito, essa opção feita pelos militares abriu caminhos para o que Vianna (1998) denomina “americanização" perversa da seguridade social brasileira, na qual há uma tendência 
de divisão da prestação de serviços sociais entre ramos públicos e privados. Nestes, a qualidade do serviço é melhor e o acesso se restringe às classes médias e altas; naqueles, o fornecimento é, teoricamente, universal, mas a qualidade do atendimento é mínima. Assim, surge um problema de estratificação bastante grave, no qual a política social ganha contornos regressivos, semelhante ao modelo liberal e especialmente ao norte-americano.

Tal tendência privatista dos governos militares inaugurou, em terras tupiniquins, dispositivos caracteristicamente anglo-saxões de welfare, como o desconto no imposto de renda de gastos feitos com saúde e educação privadas, além de financiar diretamente organizações particulares de saúde. Na minha perspectiva, essa opção privatizante feita pelo regime de 1964 definiu padrões que criarão raízes e se proliferarão no período democrático posterior que, mais do que um período de expansão do universalismo, seria também um momento de desenvolvimento da matriz liberal do welfare state brasileiro. Nele, ocorreu a consolidação de políticas sociais focalizadas de renda condicionada, como o Bolsa Família, e multiplicação do financiamento a serviços privados de saúde e educação por meio do sistema de vouchers, cujo maior exemplo seria o programa ProUni. Dessa forma, configurar-seia o que chamo de guinada liberal da seguridade social brasileira. Esse será o tema do próximo capítulo. 


\section{As políticas sociais brasileiras após a CF de 1988}

\subsection{Introdução}

O regime de políticas sociais brasileiro foi, ao longo de sua história, marcado por um viés altamente corporativo. Seu modelo de proteção social, de inspiração claramente bismarckiana, colocava como condição de acesso o pertencimento a determinadas categorias ocupacionais reconhecidas pelo Estado, cujos sindicatos estavam, eles também, sob tutela estatal. Esse modelo, como vimos, nasce com Vargas a partir da revolução de 1930, respondendo a demandas antigas dos trabalhadores, ao mesmo tempo que agia no sentido de realizar o alargamento da atuação estatal no sentido da incorporação dos setores subalternos por meio da intervenção direta do Estado no embate capital/trabalho (VIANNA, 1978). Na ditadura militar, esse regime, que Santos (1979) denominou cidadania regulada, permaneceu em vigor, embora matizado por uma certa guinada universalista, acompanhada também dos primeiros passos em direção a um welfare state de tipo liberal com o desenvolvimento do ramo privado da saúde. Trata-se, portanto, de um modo de organização institucional bastante resiliente na experiência brasileira de políticas sociais.

Tal continuidade seria finalmente quebrada pela Constituição Federal de 1988, que configurou uma verdadeira virada normativa da proteção social brasileira. $\mathrm{O}$ principal objetivo expresso no documento é o de configuração de um Estado de bemestar universalista, marcado por princípios como atendimento à necessidade, acesso amplo, benefícios não-contributivos etc. Distancia-se, destarte, do esquema da cidadania regulada, que buscava conformar as relações Estado/sociedade por meio do vínculo empregatício. A partir da nova $\mathrm{CF}$, os benefícios da seguridade e a prestação de serviços como educação e saúde ganham status de direitos sociais, vinculando o acesso a eles à própria condição de cidadania do brasileiro. Essa configuração faria com que Kerstenetzky (2012) denominasse esse período como "universalismo estendido", apontando para o alargamento do alcance das políticas universalistas quando comparado ao "universalismo básico" dos governos militares.

Entre a intenção embutida na Carta e sua concretização real sob a forma de políticas sociais existe, todavia, uma grande distância. Neste capítulo, analisarei o 
percurso da proteção social brasileira a partir do marco engendrado pela CF de 1988, buscando elucidar seus aspectos gerais, com ênfase especial nos governos FHC, Lula e Dilma. Nesse sentido, o recorte abrange especialmente três grandes áreas: saúde, educação e assistência social, e em algumas de suas políticas específicas, como o ProUni e o Programa Bolsa Família. Nelas, concentro o estudo em torno de duas variáveis principais: a composição público/privada na provisão de serviços, e as características liberais ou universais das políticas. A partir dessa estrutura analítica, almejo testar a hipótese de que, mais do que um "universalismo estendido", esse período posterior à CF de 1988 seria marcado por duas tendências principais e, ao menos aparentemente, divergentes: uma, de expansão da provisão pública universal de serviços sociais e seguridade; outra, de consolidação e fortalecimento da participação privada, somada a um ganho de importância de políticas sociais de inspiração anglo-saxã, como as transferências condicionadas de renda. Argumento, então, que o welfare state que surge orientado a partir desses dois eixos privado/focalizado e público/universal - tem um caráter essencialmente dual e híbrido, situando-se entre o regime liberal e o social-democrata analisados por Esping-Andersen (1990).

\subsection{A proteção social na Nova República (1994-2016)}

A Constituição Federal de 1988 inaugurou um período completamente novo na história das políticas sociais brasileiras. Partindo do regime da cidadania regulada que, a despeito de transformações ao longo da ditadura militar, mantinha-se ainda predominante na estruturação do welfare state nacional, a CF de 1988 lançou as bases para o modelo universalista da seguridade social. Segundo Fleury (2009, p. 472-480), nesse modelo "busca-se romper com as noções de cobertura restrita a setores inseridos no mercado formal e afrouxar os vínculos entre contribuições e benefícios, gerando mecanismos mais solidários e redistributivos". Esses objetivos respondiam a demandas colocadas por movimentos sociais que se reorganizavam desde meados dos anos 1970 em meio ao regime autoritário. Em sua luta pela democracia, esses grupos passam a incorporar a dimensão dos direitos sociais no escopo de sua concepção republicana. Destarte, ao término dos governos militares, em 1985, os setores então organizados em torno dessa bandeira - que incluíam o novo sindicalismo em ascensão, movimentos reivindicatórios urbanos, a frente partidária de oposição etc. têm suas demandas liberadas, exercendo intensa pressão sobre a tomada de decisões 
em torno dos processos de policy making e, especialmente, sobre a Constituinte e o pacto republicano que viria a ser formulado (REIS, 1989).

Tais pressões se refletem no texto da Carta Constitucional, que consagra a proteção social como um direito inerente à cidadania, reservando todo um capítulo para essa temática. Nele, a CF estabelece como metas da política social brasileira a universalização do acesso, privilegiando a concessão dos benefícios segundo a necessidade dos usuários - em detrimento à filiação ocupacional, característica do modelo corporativo anterior - baseada em princípios de justiça social, enfatizando a responsabilidade do Estado na promoção da seguridade e tendo a descentralização e cooperação entre os entes federados como meio (FLEURY, 2009). Além disso, o constituinte, cuja experiência recente era de um regime autoritário, almejava garantir o caráter participativo dessas políticas sociais, pondo ênfase sobre a deliberação conjunta entre Estado e sociedade na definição dos rumos a serem seguidos. O art. 194 sintetiza essas concepções ao definir a Seguridade Social como "um conjunto integrado de ações de iniciativa dos Poderes Públicos e da sociedade, destinadas a assegurar os direitos relativos à saúde, à previdência e à assistência social” ou, conforme sintetiza Fleury (2008, p. 9):

"O novo modelo foi expresso nos princípios organizadores da Seguridade Social: universalidade da cobertura e do atendimento; uniformidade e equivalência dos benefícios e serviços às populações urbanas e rurais; seletividade e distributividade na prestação dos benefícios e serviços; irredutibilidade no valor dos benefícios e serviços; equidade na forma de participação do custeio; diversidade da base de financiamento; e gestão quadripartite, democrática e descentralizada, com participação dos trabalhadores, dos empregadores, dos aposentados e do governo em órgãos colegiados. Além disso, introduziu a noção de uma renda de sobrevivência, de caráter nãocontributivo, ao assegurar um benefício financeiro de prestação continuada para idosos e deficientes incapazes de trabalhar".

Os três setores da previdência, saúde e assistência social foram, então, unificados sob a bandeira da Seguridade pela primeira vez, configurando um objetivo de gerir, de forma unificada, as políticas sociais brasileiras no intuito de concretizar a democracia social (FLEURY, 2008). A tal figura jurídica, somou-se a determinação de desenvolvimento de um Orçamento da Seguridade Social, em separado do Orçamento Fiscal, que visava garantir a sustentabilidade financeira dessas três áreas a despeito das oscilações das conjunturas políticas e econômicas. As principais fontes de financiamento seriam as seguintes: contribuições de empregados, empregadores e autônomos; contribuições sobre o lucro líquido das empresas (CSLL); e contribuições sobre o faturamento das empresas (COFINS). Tal organização unificada, porém, 
jamais aconteceu, na medida em que, preocupadas com sua sustentação individual, as áreas passaram a disputar os recursos, ficando a previdência com o mais vultuoso deles, os descontos em folha.

Ocorre, porém, que, segundo Fleury (2008), o contexto político que permitiu o desenvolvimento da Constituição Cidadã se transformou. Muitos dos preceitos constitucionais, que dependiam de regulações posteriores, tiveram que passar por prolongadas disputas para entrarem em vigor. Em alguns desses casos, a vitória foi dos grupos favoráveis ao modelo universalista preconizado pela Carta; em outros, foi das forças alinhadas com o pensamento neoliberal e que, diferentemente, viam o peso fiscal engendrado pela Seguridade como insustentável. A LOAS, por exemplo, foi alvo de intenso debate, sendo, finalmente, aprovada e culminando na criação do Sistema Único de Assistência Social (SUAS), capaz de integrar e coordenar os diversos benefícios, tanto constitucionais - como o Benefício de Prestação Continuada (BPC) - quanto aqueles criados por lei ordinária - como o PBF. Tais disputas, vale dizer, aconteciam desde a Assembleia Constituinte. Nela, contudo, a coalização política vitoriosa costumava ser aquela vinculada aos movimentos sociais e aos especialistas em políticas sociais. Foi o caso da disputa em torno da criação do SUS, quando representantes do Centro Brasileiro de Estudos em Saúde (CEBES) e da Associação Brasileira de Pós-graduação em Saúde Coletiva (Abrasco) se reuniram na Plenária Nacional da Saúde para fazer frente à pressão das entidades representantes de provedores privados de saúde, especialmente a Associação Brasileira de Medicina de Grupo (Abramge) e a Federação Brasileira de Hospitais (FBH).

A Assembleia Constituinte de 1988 foi, então, palco de muitas lutas e o documento dela originário serve, nesse sentido, não somente como base para a formulação da proteção social, mas, também, como norte a ser perseguido pelos policy makers, abrindo caminho para a expansão da seguridade brasileira. É assim que, entre 1988 e 2008, os gastos sociais do governo basicamente triplicaram, crescendo quase duas vezes mais rápido que o produto e a população. A rubrica que mais cresceu foi a das transferências da seguridade social, especialmente a previdência, sendo responsável por mais da metade do que o país despendeu como gasto social público no período. Entre os novos direitos chancelados pela Constituição de 1988 estão: 
“a universalização da previdência (universalização do acesso no meio rural), a assistência social a quem dela necessite, a universalização da educação fundamental e média e da saúde em todos os níveis - esta se convertendo em direito do cidadão e dever do Estado -, a designação do salário mínimo como o valor piso para os benefícios constitucionais, a descentralização das políticas sociais com garantia de repasses e da capacidade arrecadatória própria pra os níveis subnacionais, a introdução do critério per capita, a participação e o controle social" (KERSTENETZKY, 2012, p. 213).

Os novos direitos, entretanto, engendraram uma pressão fiscal sem precedentes sobre os cofres públicos, de modo que criou-se um debate entre aqueles que defendiam a desconstitucionalização de direitos em prol do saneamento orçamentário do Estado e aqueles que apostavam no financiamento via impostos para as encorpadas políticas sociais. Ao longo dos governos petistas, essa última opção prevaleceu, enquanto, ao observarmos a presidência de Michel Temer, percebemos tendência oposta, como a Proposta de Emenda Constitucional 55 (PEC 55) deixa claro.

Esse conflito em torno do embate ajuste fiscal versus gasto social reflete, além de divisões em diversos setores da sociedade civil, clivagens distintas entre as elites dirigentes do país, cuja importância para o processo de desenvolvimento do welfare state nacional é central. Nesse sentido, Reis (2000), em artigo que analisa quatro grupos dirigentes principais - sindical, empresarial, político e burocrático - mostra como as diversas elites convergem na importância que dão à temática da pobreza e da desigualdade, vendo-a como um problema nacional de primeira ordem e coincidindo, também, em suas visões a respeito do responsável pelo problema. Assim, todas as elites, e especialmente os empresários, culpam o Estado pelo fracasso das políticas sociais, afirmando que ele - e também os políticos especificamente - não cumpririam sua função primordial de prover a população com serviços de qualidade. É curioso, aliás, que mesmo os políticos e a alta burocracia veem o Estado como um ente externo que não executa bem sua responsabilidade social. Nas palavras de Reis (2000, p. 148):

"Aparentemente, as indicações são no sentido de que a elite não se sente responsável pelo problema da pobreza e da desigualdade. Ela transfere claramente a responsabilidade sobre ele ao Estado. É o Estado que carece de vontade e que não planeja bem suas ações. Mesmo a elite política - no caso, os parlamentares no Congresso - e a elite burocrática - aquela que ocupa as posições superiores da burocracia pública - não se vêem como Estado. Nesse sentido, elas parecem ter uma atitude clientelística diante do Estado: este deveria buscar soluções para problemas sociais que, no limite, trazem externalidades negativas para os não-pobres".

Ocorre, porém, que, se essas elites convergem na visão do Estado como origem do problema, diferem profundamente na sua visão a respeito das possíveis soluções. 
Dessa forma, para os grandes empresários entrevistados pela autora, desregulamentar a economia e controlar o crescimento populacional aparecem como políticas públicas prioritárias para o combate à desigualdade, seguidas pelo aumento da eficiência dos serviços públicos, enquanto, para as demais elites, a prioridade seria a realização da reforma agrária. Ao mesmo tempo, Reis (2000) aponta que, a despeito de reconhecerem a profundidade do problema da desigualdade e da pobreza e verem as políticas públicas estatais como ineficazes para encaminhar possíveis soluções, essas elites não mostram interesse real em participar ativamente na busca de caminhos de resolução alternativos, sejam eles via mercado, sejam via sociedade civil. Mais do que isso, não almejam assumir maiores custos para a solução do problema, rejeitando a possibilidade de aumentos de impostos que viessem a ampliar o potencial da atuação do Estado, na crença de que o problema não reside em uma escassez de recursos, mas sim em sua má aplicação. Isso explicaria a ênfase das elites empresariais na desregulamentação da economia e na diminuição do tamanho do Estado via corte de gastos, cujos desdobramentos empíricos seriam os embates em torno do conflito ajuste fiscal versus ampliação de gastos sociais, mobilizando empresários, de um lado, e movimentos sociais, lideranças sindicais e determinados grupos políticos, de outro, como Fleury (2008) analisou para o caso da saúde no período da Constituinte.

Tal disputa permanecerá ao longo da Nova República, variando os atores em cena, seu posicionamento e os grupos que prevalecem. Nesse sentido, Kerstenetzky (2012) afirma que podemos dividir o período pós CF entre 1988 e 2009 em seis subperíodos principais: 1988 a 1990, 1991 a 1992, 1993 a 1998, 1999 a 2003 e 2004 a 2009, cujas variações em termos de inflexão das políticas sociais se dariam devido aos embates no eixo ampliação de gastos versus ajuste fiscal. Seus desdobramentos em termos de policy making ocorrem em torno de quatro variáveis principais, quais sejam: o caráter expansionista do gasto social, a intensidade das políticas de austeridade, as taxas de crescimento econômico e as estratégias governamentais de articulação entre essas restrições. Entre elas, o crescimento econômico aparece como um dos principais fatores explicativos em torno da variação do gasto social, sendo o governo FHC aquele que mais confiou no mercado como provedor de welfare. A partir de 2004, no primeiro governo Lula, há uma certa inflexão nas políticas sociais, de modo que passam a ser vistas como capazes, elas mesmas, de gerar efeitos econômicos positivos, configurando o que se denominou políticas sociais 
economicamente orientadas (KERSTENETZKY, 2012). Ainda assim, mesmo nos períodos expansionistas dos governos petistas, não é colocada ênfase notável sobre os serviços, especialmente educação, de modo que o gasto social cresce muito mais a partir de um ponto de vista inercial - especialmente com o aumento de pagamentos da previdência - do que propriamente a partir de estratégias de inovação institucional em torno de políticas de promoção social ${ }^{11}$.

Após a Constituição Federal de 1988, têm-se um primeiro período, de 1988 a 1994, no qual ainda se fazem sentir, de forma inicial e, às vezes, brusca, os efeitos de suas determinações no campo social. A criação do seguro-desemprego, financiado a partir de uma contribuição patronal e gerido pela previdência, do Sistema Único de Saúde (SUS), a partir do qual os municípios passam a ser os principais captadores de recursos e gestores da rede pública, e a aplicação de novas regras universalizantes da Previdência Rural, com a redução da idade mínima para acesso e a elevação do piso para o salário-mínimo, são alguns dos desdobramentos imediatos da carta, ampliando, em larga medida, os gastos sociais do Estado. A Previdência Rural, principalmente, deu um grande passo na direção do universalismo ao incluir uma série de "segurados especiais", como trabalhadores da agricultura familiar, que não tinham contrapartida contributiva direta, entre seus beneficiários.

Esse primeiro ímpeto expansionista é freado já em 1994 pelas restrições fiscais colocadas pela inflação crescente. No contexto do Plano Real, é criado um fundo chamado de Desvinculação das Receitas da União (DRU), que permite utilizar rendas de forma distinta das destinações constitucionais, especialmente os gastos sociais. A DRU permite que o governo, anualmente, utilize até $20 \%$ dos recursos destinados à Seguridade Social para honrar compromissos com o pagamento da dívida pública, a título de flexibilização (FLEURY, 2008). Assim, na Seguridade Social, a União passa a ser isenta de complementar seu orçamento e, ainda mais, passa a utilizar fontes até então reservadas somente para a Seguridade no refinanciamento da dívida pública. Além disso, outras contribuições, como a já extinta CPMF, criada para financiar o SUS, tiveram seus recursos utilizados para outros fins, geralmente vinculados à realização do superávit primário.

\footnotetext{
${ }^{11}$ Castro et al (2012) dividem as políticas sociais em dois tipos principais: políticas de proteção social e de promoção social. As primeiras são a previdência, a saúde e a assistêncial social; as segundas, trabalho e renda, educação, desenvolvimento agrário e cultura.
} 
Tal esforço contracionista continuaria e até mesmo se aprofundaria no período FHC (1995-2002), que, de acordo com Kerstenetzky (2012), foram marcados pela necessidade de estabilizar a economia, primeiro frente à escalada inflacionária e, depois, perante as consequências criadas pelas medidas de combate à inflação. A perda de prioridade das políticas sociais é notada especialmente na variação do gasto social, cuja participação relativa no gasto público total diminui, caindo de $30 \% \mathrm{em}$ 1994 para 26\% em 2002. Fica ainda mais aquém, portanto, do mínimo de 50\% visto em muitos países da OCDE.

Somado à perda orçamentária, ocorreu também um duplo processo de recalibragem das políticas sociais. O primeiro, de caráter interno, buscava aumentar a eficiência e a eficácia do gasto, focando-o, portanto, no atendimento aos mais pobres e às necessidades mais básicas dos beneficiários. É assim que, na educação, o governo FHC prioriza o nível fundamental; na saúde, o foco recai sobre o atendimento básico; na previdência, busca-se a saúde financeira e a equidade entre os já incluídos, enquanto na assistência social se priorizam as maiores novidades do período: os programas de renda condicionada focalizados nos mais pobres. No segundo mandato, prioriza-se a recalibragem externa, isto é, entre políticas, destinando mais recursos às políticas de renda focalizada, às custas principalmente da previdência, um leve aumento nos gastos da saúde e manutenção daqueles com educação (GUERREIRO, 2010).

Na previdência, a emenda constitucional $\mathrm{n}^{\text {o }} 20$, de 15 de dezembro de 1998, intensifica a sua consistência atuarial, ao mesmo tempo que busca combater suas características segregacionistas herdadas do modelo da cidadania regulada. O principal inimigo a ser combatido consiste na tendência deficitária da previdência, que colocava-a, na perspectiva das coalizão de governo de então, como grande vilã do orçamento da União. Objetivava-se, assim, diminuir os benefícios especiais dos segurados do setor público, cujo peso fiscal era superior (KERSTENETZKY, 2012). Essa meta foi perseguida por meio do aumento do tempo de contribuição e introdução do fator previdenciário, bem como pela homogeneização das categorias de segurados. De positivo, a reforma universalizou a cobertura do salário-maternidade, mas não abordou a questão dos trabalhadores informais, que permaneciam descobertos pela previdência. 
No campo da assistência, em 1996, seguindo determinação constitucional, é implementado o Benefício de Prestação Continuada (BPC) no lugar da Renda Mínima Vitalícia (RMV), herdada do regime militar. O BPC consiste em um benefício no valor de um salário mínimo voltado para idosos pobres e deficientes físicos cujas famílias não sejam capazes de prover o sustento, isto é, cujos rendimentos sejam inferiores a $1 \frac{1}{4}$ de salário-mínimo per capita (BRASIL, 2011). Ao mesmo tempo, O BPC possui uma cobertura maior do que da antiga RMV, pois a idade mínima dos idosos pobres cai dos 70 anos para os 67. Em 2011, essa cobertura seria ainda mais ampliada pela lei $\mathrm{n}^{\mathrm{o}} 12.435$, que diminui a idade mínima de acesso ao benefício para 65 anos (BRASIL, 2011). Além disso, para a manutenção do benefício, a condição do recipiente deveria ser reavaliada a cada 2 anos, mantendo-se o pagamento se comprovada a permanência da condicionalidade.

Nesse formato, o BPC foi bastante eficaz em sua proposta de redução da pobreza, tanto pelo volume de seu benefício, equivalente a um salário-mínimo, quanto por sua cobertura ampliada. Sendo um benefício constitucional, possui, ademais, proteção legal, estando protegido frente a oscilações na conjuntura política (KERSTENETZKY, 2012). Sua institucionalização fez a rubrica da assistência social no gasto social federal saltar de $1,7 \%$, em 1995, para 2,8\%, em 2002, enquanto, como proporção do PIB, pulou de $0,1 \%$ para $0,6 \%$ no mesmo período (CASTRO e CARDOSO JR., 2005).

A despeito de seu benefício mais elevado, não é o BPC que assume a dianteira dos gastos em assistência social entre 1995 e 2002. A frente é tomada por uma notável inovação institucional do período: as políticas focalizadas de renda condicionada, que saltam de uma participação de 7\% em 2000 para 36\% em 2002, superando os demais gastos da rubrica, inclusive o próprio BPC. Tais políticas chamam-se focalizadas porque, diferentemente das políticas universalistas características do regime social-democrata, elas focam em setores específicos da população: nesse caso, os mais pobres. São condicionadas pois, enquanto os programas característicos do modelo escandinavo não exigem contrapartidas, essas políticas, de inspiração claramente liberal ou anglo-saxã, demandam determinados comportamentos por parte dos beneficiários para que seus pagamentos sejam realizados. No período, a principal contrapartida exigida era a presença das crianças e 
jovens das famílias beneficiárias na escola, como ocorria no programa Bolsa Escola, cujo benefício atingiu até cinco milhões de famílias (KERSTENETZKY, 2012).

A saúde também passa por uma série de reformas, com a divisão de competências entre estados, União e municípios, sendo que estes passam a arcar com a maior participação relativa no financiamento e prestação de serviços de saúde. Em 1996, é criada a CPMF para estabilizar o financiamento da saúde, e, em 1997, é fixado um gasto mínimo por habitante, além de ocorrer a vinculação de receitas tributárias das três esferas de governo no ano 2000. A lei dos medicamentos genéricos, em 1999, foi outra das principais conquistas do governo no sentido de deixar os medicamentos mais acessíveis para as pessoas mais pobres. Contudo, Kerstenetzky (2012) ressalta que, a despeito dessa nova legislação, os gastos com saúde aumentaram pouco entre 1994 e 2002, em torno de apenas meio ponto percentual do PIB, estando ainda muito aquém dos níveis praticados nos países desenvolvidos da OCDE em termos per capita.

Na educação, as medidas de recalibragem deram prioridade total para o ensino fundamental, cujos gastos se expandiram, frente a um decréscimo ou estagnação nos níveis médio, superior e infantil. Esse viés acabou por desviar recursos municipais única esfera de governo responsável pelo financiamento dessa área - do ensino infantil, em direção ao nível fundamental, e aumento o peso desta categoria também nos gastos estaduais, que são os maiores responsáveis pelo nível médio. No que tange ao nível superior, ocorreu uma expansão das instituições privadas de ensino e crescimento da oferta de vagas nas universidades públicas sem o necessário acompanhamento de investimentos em profissionais e infraestrutura. Nesse contexto, em que, mais do que aumento de gastos, houve recalibragem entre as políticas de educação, o gasto per capita manteve-se bastante abaixo dos países da OCDE e até mesmo inferior a vizinhos latino-americanos (GUERREIRO, 2010).

No que toca às políticas de emprego, houve recalibragem a favor das políticas ativas de mercado de trabalho, isto é, aquelas que promovem a reinserção e capacitação dos trabalhadores, ampliando e melhorando a oferta de trabalho (KERSTENETZKY, 2012). As políticas passivas, por sua vez, experimentaram crescimento ao longo do primeiro mandato - devido, especialmente, ao aumento de pagamentos do seguro-desemprego derivado da recessão econômica -, caíram entre 1999 e 2000 e, entre 2001 e 2002, apresentaram novo crescimento. 
No primeiro governo FHC, houve maiores avanços na questão agrária, a despeito da relação tensa entre o MST e as lideranças governamentais, com crescimento de $45 \%$ nos gastos de organização agrária entre 1995 e 1998. Ao longo dos dois mandatos, foram assentadas mais de 600 mil famílias, maior quantidade de assentamentos durante um mandato presidencial até então (KERSTENETZKY, 2012).

Por fim, os governos FH foram marcados por uma série de iniciativas no campo das políticas sociais e por algumas inovações institucionais notáveis, cujo maior destaque são as políticas focalizadas de renda condicionada. Outras modificações também aconteceram, especialmente a descentralização da provisão de serviços sociais, que caminharam na direção da responsabilização dos municípios e, também, a descentralização das formas de arrecadação, visando capacitar estados e municipalidades para executar suas novas funções (KERSTENETZKY, 2012). A participação também se aprofundou, com a instalação de conselhos para o gerenciamento e controle das políticas públicas.

A despeito desses avanços, a principal marca do período de 1995 a 2002 não foi de notável melhoria qualitativa das políticas sociais brasileiras, mas, sim, de recalibragem dos diversos mecanismos de proteção social em direção ao provimento de recursos básicos, especialmente para os mais pobres, como ficou claro na ênfase colocada no ensino fundamental, em detrimento ao infantil, médio e superior. Além disso, Kerstenetzky (2012) ressalta que o mindset da gestão tucana colocava sempre o gasto social apenas como mais uma rubrica no gasto público, esquecendo que ele poderia desempenhar funções também econômicas. Assim, para fortalecer a proteção social, era necessário, primeiro, fazer o país crescer e, para fazê-lo crescer, era mister realizar o ajuste fiscal, dando às políticas sociais um caráter cíclico. Ao invés, portanto, de se enquadrar as políticas sociais de forma economicamente orientada, buscando utilizá-las para amortecer os momentos de crise, elas seguiam a tendência geral do ciclo econômico, se reduzindo em momentos de baixa atividade e arrecadação. Esse ponto de vista mudará nos governos petistas, quando as políticas sociais são vistas não como gastos, mas como investimentos.

Para Kerstenetzky (2012), a principal inovação dos mandatos Lula (2003-2010) foi apostar na interação entre políticas sociais e políticas econômicas, vendo as primeiras como capazes de relaxar suas próprias restrições orçamentárias e, mais do 
que isso, como vetores de crescimento econômico. Embora mantenha-se a prioridade absoluta na estabilidade econômica - ao menos entre 2003 e 2005 -, com uma política monetária contracionista - juros elevados - e uma política fiscal que continua preocupando-se muito com a realização de superávits primários, existiu uma forte ativação dos gastos sociais, especialmente no período entre 2006 e 2009. Ademais, a ênfase das políticas sociais recaiu sobre a assistência social, seguindo tendência inaugurada nos governos FHC. Ao mesmo tempo, os serviços de saúde e educação especialmente básica - receberam pouca atenção, apesar de sua importância elevada para a superação da condição de subdesenvolvimento do país (KERSTENETZKY, 2012).

Nesse sentido, o Programa Bolsa Família (PBF) ganha destaque, convertendo-se em uma das principais marcas dos mandatos Lula e Dilma. Implementado em 2004, seu objetivo é realizar um alívio imediato da pobreza por meio de transferências monetárias condicionadas ao cumprimento de determinadas exigências, como a presença dos filhos na escola. Logo de início, o programa tem escala duas vezes maior que os que buscava substituir, como o Bolsa Escola e o vale-gás, já superando, em seu primeiro ano de funcionamento, a marca de 6,5 milhões de famílias beneficiadas. Em 2010, último ano de governo do líder petista, o número de famílias que recebiam o benefício já havia ultrapassado 12,7 milhões, crescimento de quase $100 \%$.

Quadro 2- Nº de famílias beneficiárias do PBF

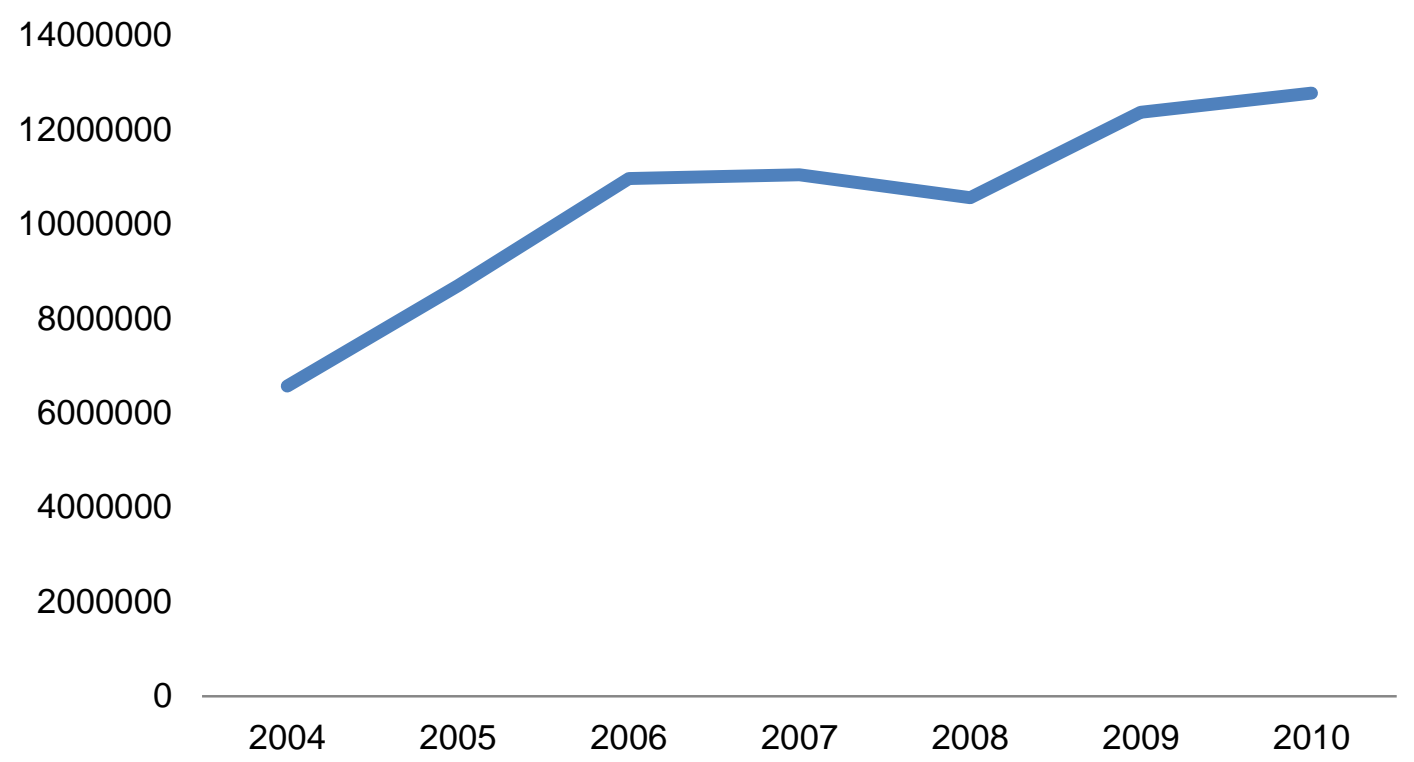

Fonte: elaboração própria com dados do MDS (2015) 
O gráfico mostra que houve um incremento bastante razoável no número de beneficiários do PBF ao longo dos dois governos Lula. Tal crescimento ocorreu de forma mais acentuada nos primeiros anos do programa, entre 2004 e 2006, experienciando uma certa estabilização entre 2006 e 2009 e, finalmente, retomada da ampliação - ainda que menos acentuada - em 2010.

Simultaneamente ao aumento de cobertura, houve, também, incremento do valor do benefício, que passou por reajustes em 2006, 2008, 2009 e 2011 (MDS, 2015). No gráfico abaixo, veremos como essas atualizações monetárias, somadas à expansão da cobertura, afetaram o gasto efetivo com o PBF.

Quadro 3 - Valor total de repasse do PBF (em bilhões)

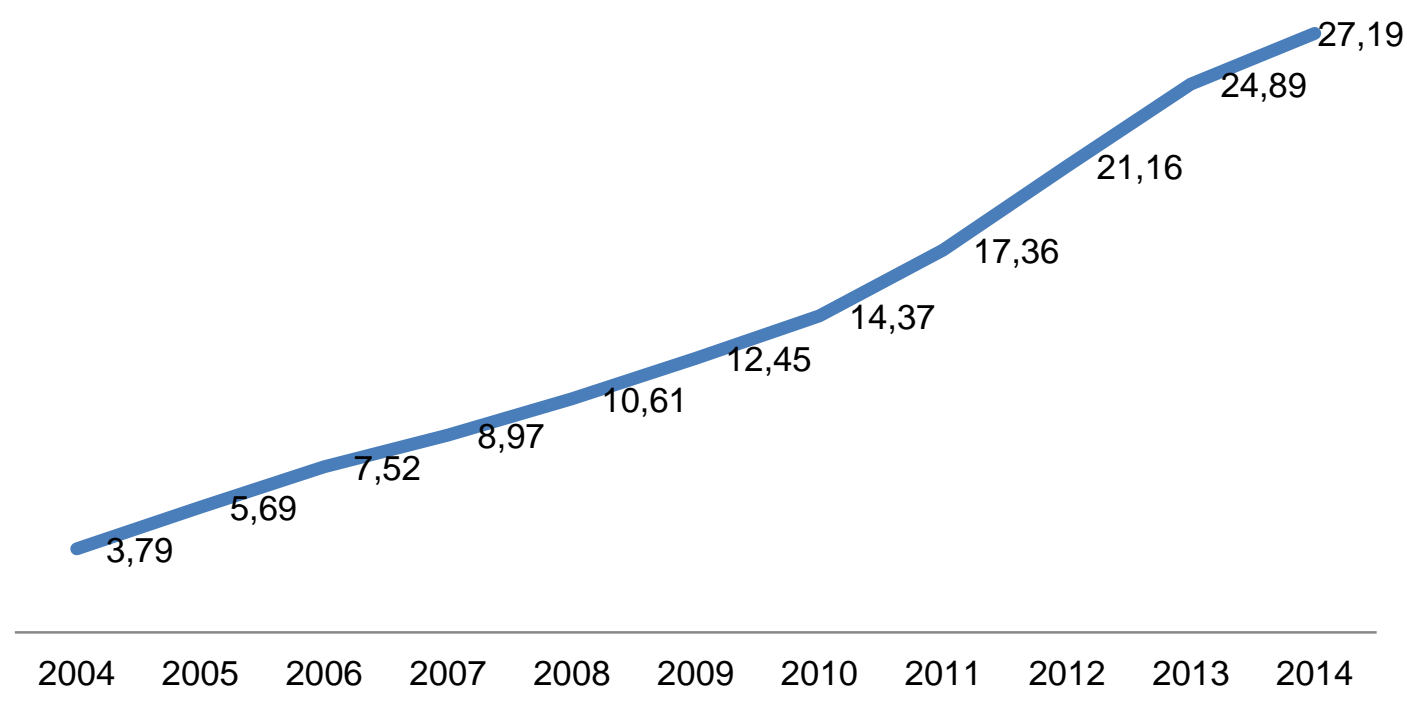

Fonte: Elaboração própria com base em dados do MDS (2015)

Fica claro, assim, que há um crescimento exponencial e constante dos pagamentos efetuados pelo PBF. Se, por um lado, o aumento no número de famílias enfrenta oscilações, o valor total de repasse tem crescimento constante, realizando uma variação positiva de mais de $600 \%$, revelando, por outro lado, a ênfase dada pelos governos petistas sobre essa política pública, cujas principais características se aproximam muito do tipo de política perseguido pelos welfare states do cluster liberal de Esping-Andersen (1990).

Segundo Kerstenetzky (2012), a ênfase no PBF está incluída no processo de valorização das chamadas políticas sociais economicamente orientadas que serviam, entre outras funções, para amortecer os momentos de baixa do ciclo econômico. 
Outros programas desse tipo eram o BPC/LOAS, o seguro-desemprego e o abono salarial, além, é claro, da política de valorização do salário-mínimo, cujos impactos no combate à pobreza, especialmente do primeiro e do último, são notáveis.

O Benefício de Prestação Continuada (BPC), como já foi dito, garante uma transferência mensal de um salário-mínimo vigente aos indivíduos com mais de 65 anos e à pessoa com deficiência, em qualquer idade, com impedimentos para a realização de atividade econômica. Ambas devem provar que não possuem condições de prover o próprio sustento e nem tê-lo provido por sua família (MDS, 2015). Nos últimos anos, a quantidade total de beneficiários do BPC saltou de 2 milhões, em 2004, para 4 milhões, em 2014.

Quadro 4 - Evolução da quantidade total de beneficiários do BPC

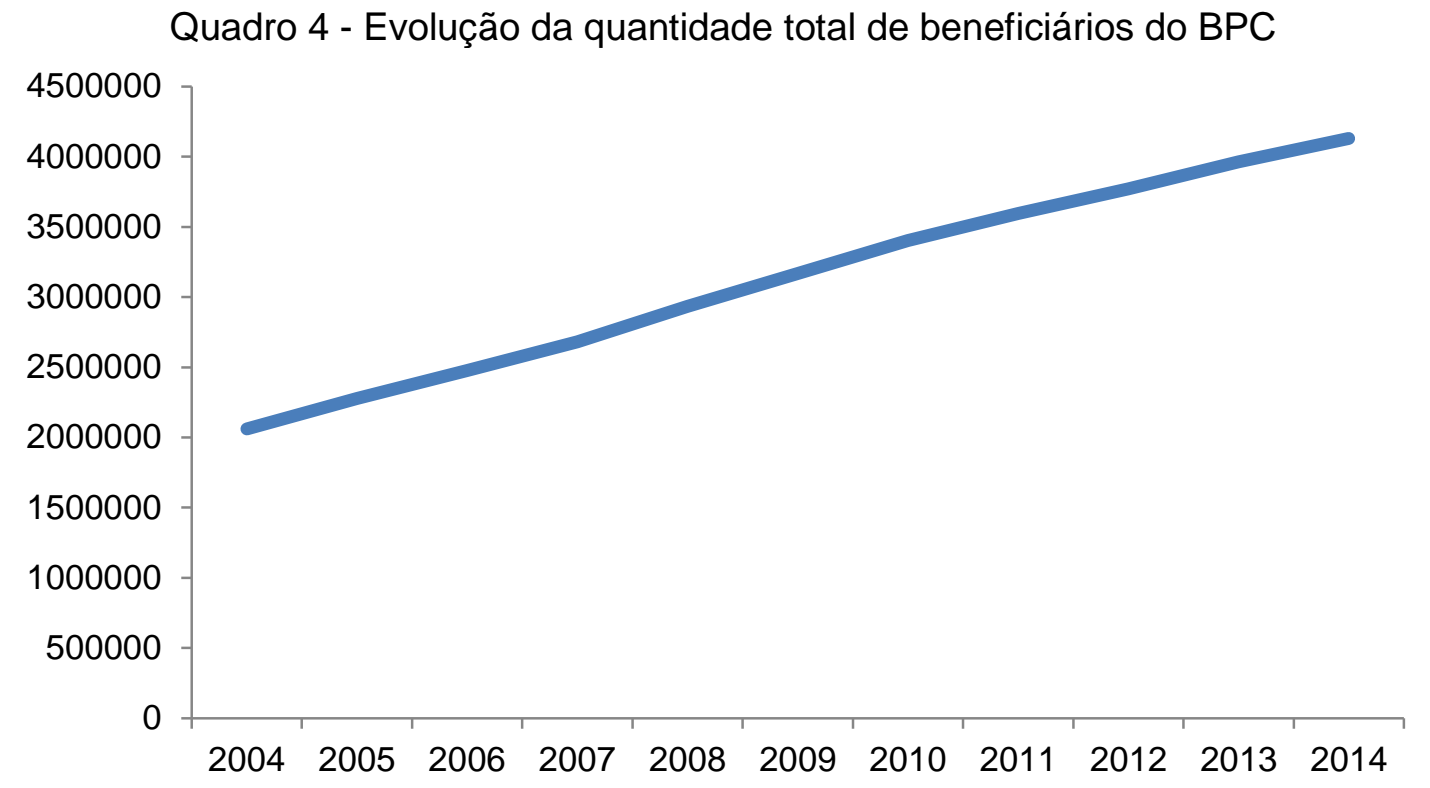

Fonte: elaboração própria com dados do MDS (2015)

Esse crescimento de $100 \%$ entre 2004 e 2010 processou-se de forma mais ou menos constante e uniforme. Por um lado, ele está vinculado ao avanço da transição demográfica brasileira, caracterizada por um amadurecimento de nossa população e, por outro, responde à pobreza estrutural que existe historicamente no país. Apesar desse alargamento da cobertura, os critérios de inclusão do BPC permanecem bastante restritivos: por um lado, a idade mínima de 65 anos já é bastante avançada considerando-se a expectativa de vida dos mais pobres, além de que o teto de até $1 / 4$ de salário-mínimo per capita para a concessão do benefício está muito aquém das demais transferências da assistência social, que é de $1 / 2$ do mínimo; por outro lado, os 
testes para provar a incapacitação para o trabalho dos deficientes são, também, muito exigentes (FLEURY, 2008).

\section{Quadro 5 - Valor total de repasses para o BPC}

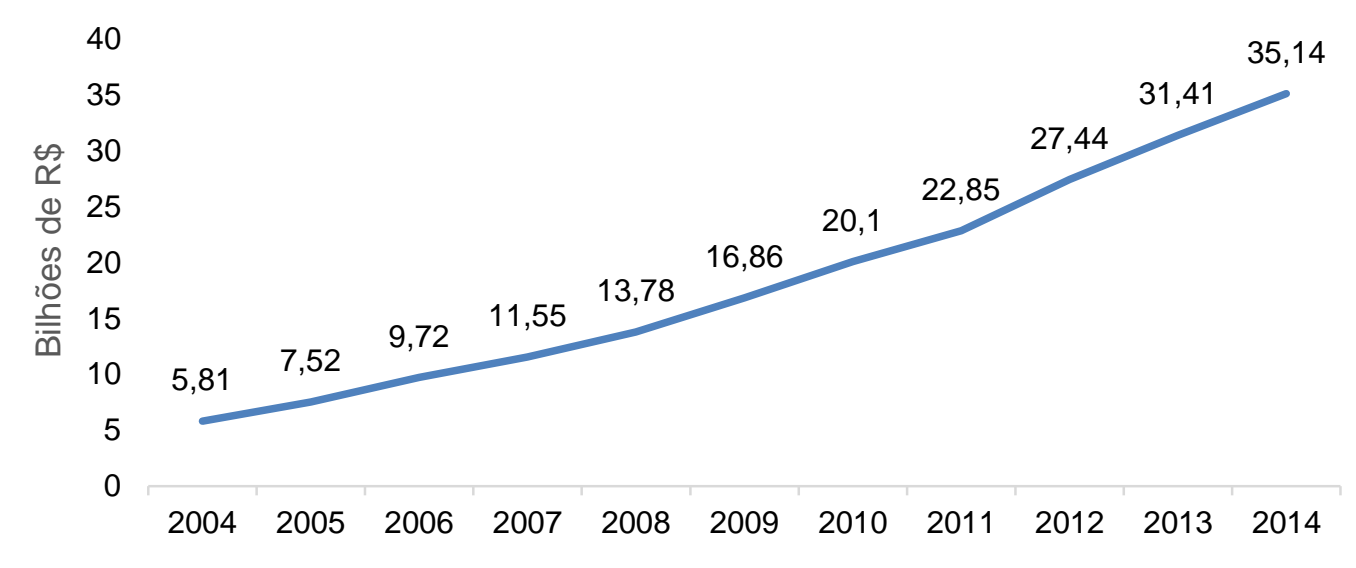

Fonte: elaboração própria com dados do MDS (2015)

A despeito das dificuldades apontadas, além do aumento da cobertura, houve, portanto, também, incremento no valor total dos benefícios pagos. Por um lado, isso se deve ao aumento de beneficiários já mostrado; por outro, a explicação reside na valorização real que o salário mínimo experimentou no período (MDS, 2015). Sendo o BPC um benefício constitucional, seu indexador é o salário mínimo, de forma que as variações deste alteram diretamente os valores pagos por aquele. Assim, com o crescimento exponencial do salário-mínimo no período, o valor total de repasses do BPC também aumentou.

A assistência social brasileira, cujos dois principais programas são o BPC, um benefício constitucional, e o PBF, uma transferência criada pelo governo Lula por meio de lei ordinária, apresenta um caráter dual, semelhante, em um certo sentido, à dualidade que vimos no sistema de saúde durante a ditadura e que, conforme veremos neste capítulo, se mantém ao longo da Nova República. Tal dualidade consiste na existência simultânea do BPC, uma transferência de tipo universalista, baseada em princípios social-democratas de uma renda básica de cidadania tida como um direito social de todos os indivíduos, e do PBF, uma política de governo de renda focalizada que visa aliviar a pobreza a partir do cumprimento de condicionalidades, característica dos welfare states do cluster liberal. Por um lado, pode se interpretar que essa ambiguidade reflete a contínua disputa por hegemonia entre os grupos defensores da agenda neoliberal vis-à-vis setores favoráveis à ampliação da ação do 
Estado na promoção do bem-estar social. Mais interessante do que essa perspectiva, todavia, é aquela desenvolvida por Fleury (2008), que argumenta a favor da tese de que, diferentemente da Inglaterra do pós-guerra ou dos países escandinavos, o Brasil apresenta uma desigualdade histórica muito profunda que precisa ser combatida. Para combatê-la, a concessão de benefícios iguais para todos é um caminho a seguir; não pode, contudo, ser o único, visto que existe a necessidade de se favorecer especialmente alguns grupos historicamente marginalizados para que eles possam fazer o catch-up com as classes médias e altas. Essas populações consistem, sem dúvida, nos pobres e muito pobres, mas incluem também outros recortes além do socioeconômico. Assim, negros, mulheres, homossexuais, indivíduos portadores de deficiência, entre outros, demandam políticas focalizadas e afirmativas que garantam seu acesso a determinadas instâncias historicamente negadas a eles. Nesse sentido, não somente o $\mathrm{PBF}$, mas outras políticas públicas, como as cotas para negros em vestibulares, atuam, por meio de uma diferenciação positiva que enfoca em determinados grupos e indivíduos, no sentido de contribuir para a construção de uma sociedade mais justa, plural e democrática.

O PBF, portanto, mais do que concorrer com o BPC, atua em conjunto a ele no objetivo comum de combater a pobreza e a extrema pobreza no Brasil, reduzindo nossas desigualdades estruturais. Como ressaltei, o BPC, sendo um benefício constitucional, é indexado pelo salário-mínimo, de forma que seu benefício é reajustado segundo as variações desse ordenado.

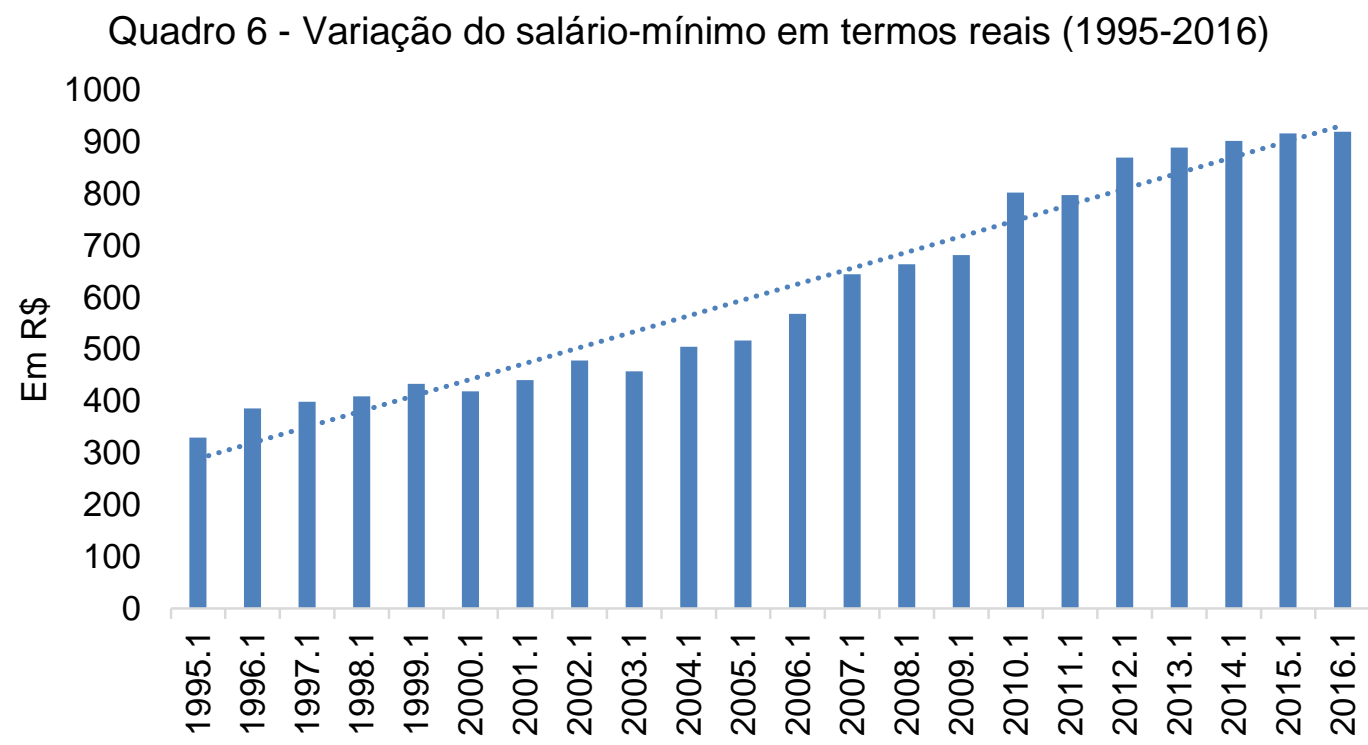

Fonte: elaboração própria, com dados do IPEAData 
O quadro 6 nos force informações importantes a respeito da política de valorização do salário-mínimo nos governos FHC, Lula e Dilma. Primeiro, pode-se observar uma tendência geral - como a linha de tendência deixa claro - de valorização do ordenado no período. Esse aumento é menor nas gestões tucanas, totalizando um incremento de $45 \%$ entre janeiro de 1995 e janeiro de 2002. Nos mandatos Lula, o incremento é bastante superior, chegando a um total de $75 \%$ de variação positiva entre janeiro de 2003 e janeiro de 2010, o que, segundo Kerstenetzky (2012), reflete o fato de que a valorização do mínimo se converteu em uma política de governo dos mandatários petistas a partir de um dispositivo que incorporava a variação da inflação e o crescimento do produto na definição do reajuste. Dilma, entretanto, apresentou um menor crescimento, em torno de 15\%, o que pode ser justificado tanto por seu menor tempo de mandato, quanto pela crise que se aprofundou nos últimos anos de seu governo. Entre janeiro de 1995 e janeiro de 2016, a valorização real do salário-mínimo foi de aproximadamente $179 \%$.

Mais importante, destarte, do que comparar os três governos, para compreendermos a dinâmica da evolução do salário-mínimo na Nova República, devemos buscar suas tendências gerais que, conforme ressaltei, são, nas últimas duas décadas, de ampla valorização. A título de comparação, entre abril de 1964, mês em que se iniciou a ditadura civil-militar, e janeiro de 1985, ano em que se encerrou, o salário-mínimo tinha sofrido uma desvalorização real de algo em torno de $50 \%{ }^{12}$, de acordo com as diretrizes do modelo de crescimento com concentração de renda que discutimos no capítulo anterior. Dessa forma, ainda que o salário-mínimo real atual em janeiro de 2016, seu valor era de $\mathrm{R} \$ 919,71$ - esteja aquém de seu máximo histórico de $\mathrm{R} \$ 1.360,87^{13}$, alcançado em outubro de 1961 , ele vinha passando por forte valorização, especialmente ao longo do governo Lula, aproximando-se dos números alcançados na experiência democrática de 1946-64, quando chegou a seu ápice. A gestão Temer, contudo, realizou um reajuste nominal em janeiro de 2017 pouco acima do IPCA acumulado de 2016, de modo que podemos esperar uma redução dos ganhos reais do mínimo também em 2018 e, caso não haja uma mudança brusca na coalização de governo nas próximas eleições presidenciais, esse cenário deve repetir-se nos anos subsequentes.

\footnotetext{
${ }^{12}$ Cálculo realizado pelo autor com dados disponíveis no portal IPEAData.

${ }^{13}$ Os valores históricos estão disponíveis, já convertidos em reais, no site do IPEAData.
} 
O efeito da valorização do salário mínimo entre 2004 e meados do primeiro mandato Dilma foi ainda amplificado pela dinâmica de emprego do período. Além dos aumentos definidos por lei, que, em si, já ampliavam os salários em termos reais, a expansão do emprego formal e a queda do desemprego contribuíram para elevar simultaneamente os salários médios e a massa salarial como um todo (KERSTENETZKY, 2012). Tudo isso, somado aos efeitos do mínimo sobre as transferências constitucionais - nas quais está incluído o BPC, mas não o PBF -, levaram a uma queda histórica de mais de 5 pontos percentuais da desigualdade medida pelo Gini, que vai de 0,572, em 2004, para 0,518, em 2014. Juntamente à queda da desigualdade, ocorreu, entre 2003 e 2013, um razoável incremento do produto brasileiro.

\section{Quadro 7 - Variação percentual do PIB}

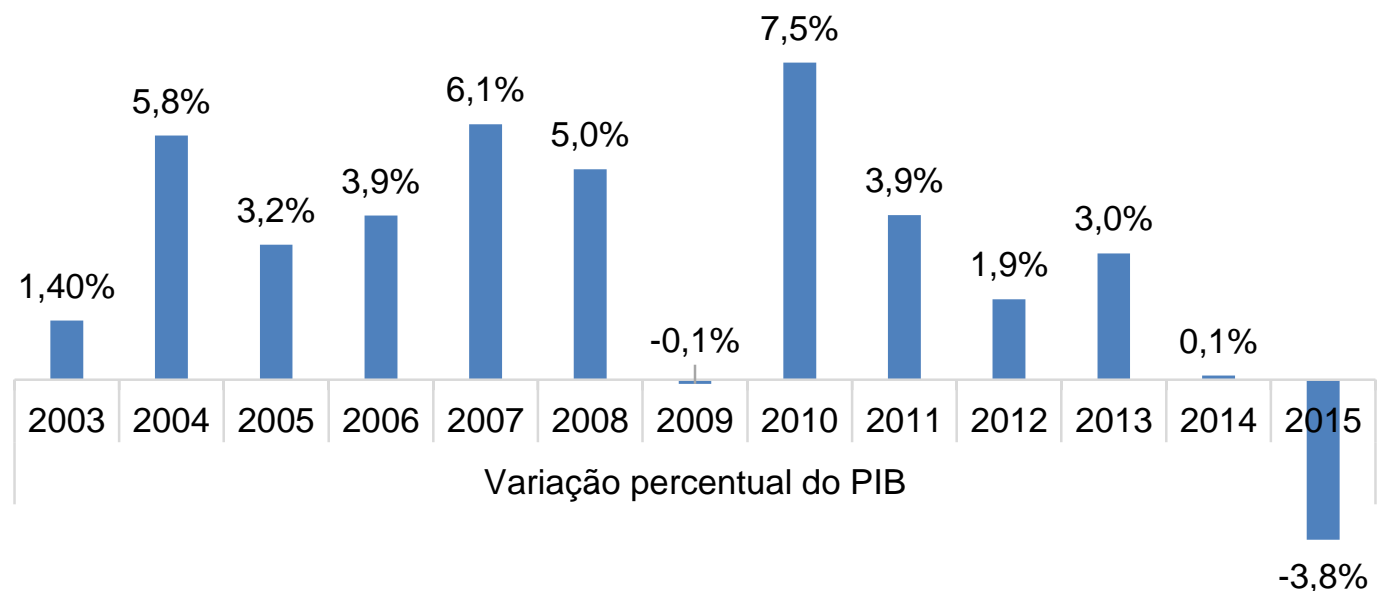

Fonte: elaboração própria com base em dados do IBGE

Tal queda da desigualdade, destarte, ocorreu em um contexto de crescimento econômico acelerado - para nossos padrões após a redemocratização -, especialmente entre 2007 e 2010, que privilegiou o acesso ao consumo dos mais pobres, culminando em um modelo de crescimento sustentado pelo consumo doméstico das classes em ascensão. Assim, setores populacionais antes excluídos do consumo, por exemplo, de bens duráveis, puderam experimentar, até meados de 2014, o acesso a espaços, serviços e produtos que somente a classe média tradicional conhecia. Esse boom de compras foi, além disso, facilitado pela expansão do crédito e pela queda da taxa de juros real promovida pelos governos petistas. Estes, aliás, compreenderam a capacidade de interação virtuosa entre as políticas sociais e econômicas, fazendo com 
que as transferências constitucionais e do Bolsa Família assumissem ares de política fiscal anticíclica e atuassem como verdadeiros estabilizadores, especialmente frente ao impacto da crise de 2008. Ao mesmo tempo, a queda da taxa de juros e facilitação do acesso ao crédito, por exemplo, para idosos e aposentados, fez com que a política monetária servisse para sanar determinadas demandas sociais por bens e serviços, configurando as chamadas políticas econômicas socialmente orientadas (KERSTENETZKY, 2012). Tal combinação de políticas possibilitou que, após a retração de aproximadamente $0,1 \%$ em 2009, já em 2010 o PIB tivesse um crescimento em torno de 7,5\%, incremento este, porém, que teria vida curta nos mandatos Rousseff, chegando a uma contração de 3,8\% em 2015.

A perda do desempenho da economia, que apareceu na retração do produto e no aumento do desemprego no início do segundo mandato Dilma, apontam para o esgotamento do modelo de inclusão via consumo preconizado pelos mandatários petistas e sinaliza para a necessidade de se ampliar os investimentos em serviços públicos sociais. No que tange à sustentabilidade do desenvolvimento socioeconômico nacional, os recursos destinados à educação ocupam lugar central e, embora tenham experimentado algum crescimento nos últimos anos, mantiveram-se muito aquém do nível dos países da OCDE e mesmo de alguns vizinhos latinoamericanos (KERSTENETZKY, 2012).

A despeito disso, a educação é o serviço que mais tem se aproximado da meta de universalização, com a maior parte do seu gasto total sendo público, principalmente no ensino primário e secundário. Ao mesmo tempo, segundo dados de Kerstenetzky (2012) em 2012, 90\% dos estudantes do ensino fundamental estavam na rede pública, em torno de $80 \%$ no nível médio e em torno de 1/3 no nível superior, apontando para a predominância da educação privada neste último. Além disso, a educação experimentou grande progresso na recuperação de seu caráter sistêmico, que havia sido deixado de lado pelas gestões tucanas em seu esforço de priorização do ensino fundamental por meio da recalibragem. Dessa forma, todos os níveis de ensino receberam investimentos, com aumento em sua participação do produto.

Ocorre, porém, que, mesmo com o aumento de investimentos e a quase universalização do acesso à educação fundamental, a qualidade do ensino manteve-se muito aquém do desejado. Como dado mais preocupante, temos o fato de que, em 2008, quase metade das crianças escolarizadas não sabiam ler nem escrever aos 14 
anos (BENEVIDES, 2011). Ademais, o Brasil continua tendo resultados péssimos em exames internacionais de qualidade do ensino, como atestou a última avaliação do Programme for International Student Assessment (PISA), realizado em 2015. O teste mostrou que o desempenho dos estudantes brasileiros encontra-se muito abaixo daqueles dos países da OCDE nas três áreas avaliadas: ciências, matemática e leitura. Na primeira, os estudantes brasileiros entre 6 e 15 anos tiveram uma média de 401 pontos, frente a 493 pontos feitos pelos estudantes de países da OCDE; na segunda, a diferença foi de 377 pontos para 490; na terceira, os brasileiros obtiveram uma média de 407 pontos, comparados a 493 dos alunos da OCDE. Não houve, também, nenhuma evolução significativa comparativamente aos exames anteriores, à exceção de matemática, que teve uma melhoria de 21 pontos entre 2003 e 2015, apesar de uma queda de 11 pontos entre o PISA de 2012 e o de 2015 (PISA, 2015). Como razões para esse baixo desempenho, o relatório final da instituição aponta para o baixo gasto acumulado por aluno do Brasil, US\$ 39.333,00, frente a US\$ 90.294,00 dos países da OCDE, assim como para a falta de qualidade desse gasto, de modo que o país foi ranqueado abaixo de outros com um custo/aluno inferior, como Colômbia, México e Uruguai. O Chile, por exemplo, com um gasto por estudante semelhante, obteve 477 pontos em ciências, muito superior ao resultado brasileiro e bastante próximo da média da OCDE.

Alguns pontos positivos, entretanto, podem ser destacados, entre eles, a tendência crescente do indicador gasto/aluno, de forma que a diferença entre o Brasil e os países da OCDE diminuiu - em 2012, o gasto brasileiro correspondia a apenas $32 \%$ da média da OCDE -, além do feito de ter expandido o acesso da população à educação sem, contudo, perder qualidade no ensino (PISA, 2015). Ademais, o país conseguiu avançar na articulação entre políticas educacionais e políticas de promoção da igualdade de gênero ao ampliar, em 65\%, o número de matrículas em creches entre 2008 e 2014 - sendo o aumento de $60 \%$ no número de crianças em creches privadas e $74,5 \%$ nas públicas -, e em $42 \%$ a quantidade total de escolas prestadoras desse serviço - com um incremento de $49 \%$ no número de creches públicas e de $34 \%$ de particulares (INEP, 2015).

Tais êxitos não alteram, todavia, a tendência crescente de segregação dentro do sistema educacional brasileiro, no sentido de que os estudantes de famílias mais abastadas tendem a migrar para as escolas privadas, cuja qualidade é, em geral, 
superior, enquanto os mais pobres permanecem na rede pública, recebendo um ensino deficiente $^{14}$. Em um contexto de emprego elevado e ganhos salariais reais, como foi entre 2004 e 2014, essa característica dual do sistema tende a empurrar os grupos ascendentes para as escolas privadas, diminuindo ainda mais a prioridade das públicas. Assim, entre 2008 e 2014, houve uma queda de 11,8\% nas matrículas em escolas da rede pública no ensino básico, enquanto as particulares experimentaram um crescimento de 28\% (INEP, 2015). Esse cenário, semelhante àquele da saúde, no qual uma rede privada de qualidade superior atende à classe média e alta, enquanto a população pobre tem como único recurso um SUS sucateado, culmina em um sistema dual que reproduz a estratificação social herdada do mercado justamente na esfera onde reside a maior esperança de ascensão social de qualquer sociedade capitalista moderna. Mais do que isso, o Estado age diretamente na sustentação desse esquema polarizado na medida em que, por mecanismos de welfare fiscal, como as isenções com gastos particulares de saúde e educação no imposto de renda de pessoas físicas, financia indiretamente o fornecimento desses serviços sociais privados para os mais ricos, agindo no sentido de perpetuar a desigualdade do acesso à instrução formal no país e, assim, a desigualdade socioeconômica como um todo.

Tal cenário, no entanto, apresenta-se de forma distinta no que tange ao ensino superior. Primeiramente, é necessário dizer que as gestões petistas recuperaram a prioridade do ensino superior dentro do planejamento educacional federal, revertendo a tendência definida por FHC, ao mesmo tempo que caminharam no sentido de ampliação do acesso somado à busca pela diversificação dos estudantes. Esse objetivo fica bastante claro na política de cotas, cujo estabelecimento engendrou mecanismos para iniciar o combate à desigualdade de acesso ao ensino superior entre brancos e negros, por um lado, e jovens com backgrounds abastados e pobres, por outro, uma das desigualdades históricas apontadas por Santos (1979) e que, segundo o autor, o esquema da cidadania regulada e a ditadura civil-militar tiveram dificuldades em fazer frente.

\footnotetext{
${ }^{14}$ A título de ilustração, segundo dados do INEP (2015), em 2014, 84\% das escolas privadas de ensino fundamental do país dispunham de bibliotecas ou salas de leitura e $93 \%$ disponibilizavam acesso à internet para os alunos. No mesmo ano, somente $45 \%$ dos estabelecimentos da rede pública fundamental dispunham de bibliotecas ou salas de leitura, enquanto apenas 50\% deles tinham acesso à internet.
} 
No que tange ao ensino superior privado, Aguiar (2016) afirma que o governo Lula teve que lidar com uma herança caracterizada por uma ampla desregulamentação do fornecimento do serviço, no que tange à qualidade, e com um problema de falta de contrapartida das instituições frente à isenção de impostos concedida pelo Estado. Assim, uma reformulação do sistema era necessária, coisa que foi tentada pela gestão petista.

Nesse sentido, as políticas de educação iniciadas no governo Lula geraram resultados ambíguos. Primeiro, no que tange ao acesso, é visível uma ampliação bastante notável do número de vagas. Isso ocorre não somente no setor público, devido ao Reuni, mas também - e principalmente - no setor privado, no qual o ProUni - que resolvia o problema da falta de contrapartida para as isenções fiscais, pois, em troca delas, exigia a matrícula gratuita de alunos carentes - teve um papel central no sentido de expandir o público do crescente mercado privado de educação superior. O FIES, que foi reformulado, passou a funcionar em fluxo contínuo, de modo que os estudantes poderiam pedir financiamentos a qualquer momento do curso, sua carência foi aumentada para 18 meses, as taxas de juros foram fixadas em $3,4 \%$ ao ano e o prazo para pagamento foi dilatado para três vezes o tempo de utilização.

A partir de sua articulação, esses dois programas conseguiram, ainda que de forma lenta, incluir setores da população antes excluídos do ensino superior, configurando não só um aumento do número de alunos, mas, também, uma diversificação de seu perfil. Isso fica visível em uma estatística oficial divulgada no final do governo Lula, segundo a qual $48 \%$ dos beneficiários são afrodescendentes (AGUIAR, 2016). Além disso, a criação da bolsa permanência, que em 2010 remunerava mais de 5.000 beneficiários do ProUni, também mostrou avanços na direção da inclusão de setores marginalizados, ainda que sua abrangência e seu benefício $(\mathrm{R} \$ 300,00)$ sejam ainda pequenos.

No que tange à problemática da qualidade, a principal inovação legal de Lula foi a criação do SINAES em substituição ao antigo Provão da era FHC. O SINAES é constituído por uma avaliação diversificada, composta pelo ENADE, prova de conhecimentos a ser aplicada em dois momentos - na entrada e saída dos estudantes do curso -, e pela visita de uma comissão ad hoc de analistas que verificam a infraestrutura do curso, seu projeto pedagógico etc. Por fim, há também a atuação de 
uma Comissão Própria de Autoavaliação (CPA). Assim, é superado o modelo do Provão, considerado por muitos analistas muito reducionista na medida em que avaliava a qualidade do curso somente por meio de uma prova teórica aplicada uma única vez. O aumento consequente do rigor das avaliações acarretou, pela primeira vez, em punições para os cursos considerados abaixo do nível mínimo, culminando no fechamento de dois cursos e na suspensão de mais de 20.000 vagas até março de 2010 (AGUIAR, 2016).

Ainda que tenham levado a avanços no acesso, diversificação e qualidade do ensino superior, as políticas engendradas nas gestões petistas para esse setor foram alvo de fortes críticas. A principal delas ataca no ponto da transferência de recursos do setor público para o privado por meio do gasto tributário, principalmente aquele vinculado ao ProUni, e no aprofundamento da segmentação entre um setor público, focado na pesquisa e no ensino de alta qualidade, com um público de maior renda, e um privado, de menor custo e frequentado principalmente por alunos mais pobres. Nesse sentido, Minto (2011) fala em um adensamento do setor privado engendrado por Lula, no qual não haveria propriamente uma aceleração do crescimento das instituições de ensino superior privadas, mas a complexificação e fortalecimento de seu sistema. Além disso, teria ocorrido um aprofundamento da mercantilização, visto que o governo não vetou a possibilidade de abertura de capital dessas empresas, transformando a educação superior, que deveria ser um bem público, em um bem de consumo cujo objetivo é gerar lucro para acionistas (MINTO, 2011).

No entanto, é necessário perceber que, se fortaleceu o ramo privado da educação superior, as gestões petistas terminaram por também ampliar as vagas nas universidades públicas. Segundo dados do INEP (2007), entre 2003 e 2007, tanto o ramo público quanto o privado tiveram crescimento constante do número de matrículas, tendo o primeiro um aumento da ordem de $10 \%$ e o segundo, de mais de $20 \%$. Entre 2003 e 2012, esse crescimento foi de aproximadamente $67 \%$, no caso das instituições públicas, e $87 \%$ nas faculdades privadas. Esse caminho de expansão simultânea somado à políticas de ação afirmativa foi aquele encontrado para permitir o acesso ao terceiro grau a grupos antes excluídos dele. Nesse sentido, o ProUni, na medida em que beneficia especialmente os mais pobres, pode ser considerado uma política redistributiva, cujos recursos, caso fossem coletados ao invés de funcionarem 
como gasto tributário, teriam destinação incerta e não necessariamente teriam efeito redistributivo semelhante (CORBUCCI, 2004).

Na educação, portanto, é perceptível uma tendência geral do sistema que atinge todos os níveis: o do crescimento, incentivado pelo Estado, do ramo privado de provisão do serviço. Tal desenvolvimento, porém, apresenta características distintas em termos de divisão público/privada que culminam em efeitos adversos na distribuição de renda. Na educação básica, os alunos mais pobres tendem a frequentar o ramo público, enquanto os mais abastados dominam o setor privado, no que costumam ser seguidos pelas classes em ascensão. Dessa forma, a manutenção da isenção do IRPF para gastos com instrução privada, somada às tradicionais isenções para as escolas desse ramo, tem um efeito regressivo sobre a estratificação social, na medida em que direciona recursos estatais para as classes médias e altas que frequentam em maioria esse setor. No nível superior, por sua vez, o acesso dos mais pobres é concentrado nas instituições privadas, enquanto os mais ricos e as camadas médias tradicionais frequentam principalmente as universidades públicas. Assim, o adensamento do setor privado proporcionado pelos governos do PT teria um efeito progressivo em termos de distribuição, na medida em que os gastos tributários do ProUni favorecem, principalmente, os mais pobres. Ademais, a política de cotas e o estabelecimento das bolsas de manutenção contribuíram, também, para a diversificação do corpo discente do ramo público, aumentando, portanto, seu potencial redistributivo.

No campo da saúde, Fleury (2009) afirma que, embora enfrentando uma série de dificuldades, o SUS conseguiu estruturar-se e vem sobrevivendo, mesmo em meio a um contexto de hegemonia neoliberal. Seu principal idealizador, o movimento sanitarista, segue com vigor buscando uma reformulação integral da forma de se pensar a saúde no Brasil. Dessa forma, o Sistema Único de Saúde seria o instrumento de execução da chamada Reforma Sanitária, meta máxima desse movimento. A Reforma Sanitária parte de uma leitura crítica a respeito da mercantilização da saúde para, então, propor sua reformulação em torno de alguns pontos principais: 1) o resgate da saúde como um bem de caráter público e como um direito de cidadania; 2) a construção de mecanismos de gestão democrática e controle social da saúde; 3 ) o reconhecimento da saúde como um fenômeno de determinação social; 4) o 
desenvolvimento de uma nova ética profissional fundada nos direitos humanos e na empatia entre trabalhador e público (FLEURY, 2009).

Apesar da força desse projeto, a tendência à fragmentação do welfare state brasileiro colocou dificuldades para a realização plena do projeto da Reforma Sanitária. O estabelecimento de vouchers (como o Prouni), o subsídio fiscal concedido a planos de saúde, o desconto no imposto de renda para pessoas físicas para gastos com serviços privados e o consequente deslocamento das classes médias para a provisão privada colocam desafios de difícil superação para projetos universais, tanto na saúde, quanto na educação (FLEURY, 2009). Destarte, pode-se dizer que, a Nova República, a despeito das intenções universalistas da Constituinte e da criação do SUS, não conseguiu desfazer-se da herança dual do sistema de saúde da ditadura militar (KERSTENETZKY, 2012).

Dessa forma, segundo dados do Cadastro Nacional de Estabelecimentos de Saúde (CNES) o sistema público continua sendo muito dependente da rede privada e filantrópica, correspondendo, em 2012, a $49 \%$ do total de leitos no país, enquanto os outros dois prestadores correspondiam a 31\% e 20\%, respectivamente. Em 2005, porém, apenas $41 \%$ dos leitos eram de provisão pública, enquanto $30 \%$ e $29 \%$ eram fornecidos por instituições filantrópicas e privadas. Trata-se, portanto, de uma evolução em direção ao aumento da provisão pública, ainda que lenta. No que tange ao consumo dos bens e serviços de saúde, de acordo com dados do IBGE, no ano 2000, o consumo final das famílias representava em torno de 5\% do PIB, enquanto o da administração pública girava em torno de 3\%. Em 2013, o consumo do governo havia crescido para 3,6\% do PIB, mas ainda ficava muito aquém do gasto das famílias que, embora reduzido, ainda equivalia a $4,4 \%$ do produto interno bruto daquele ano, ou mais ou menos $52 \%$ do financiamento da saúde. Além disso, uma parte do gasto do governo é dedicado à compra de serviços junto à rede privada, de modo que o SUS financia diretamente essas instituições. Em 2010, esses gastos equivaleram a 0,7\% do PIB ou em torno de $20 \%$ do consumo final de saúde realizado pelo governo; em 2013, o número foi de $0,6 \%$ do PIB. Não houve, portanto, uma variação considerável nesse indicador (IBGE, 2015). 
Quadro 8 - Consumo de bens e serviços de saúde, como percentual do PIB, por setor, Brasil, 2000-2013

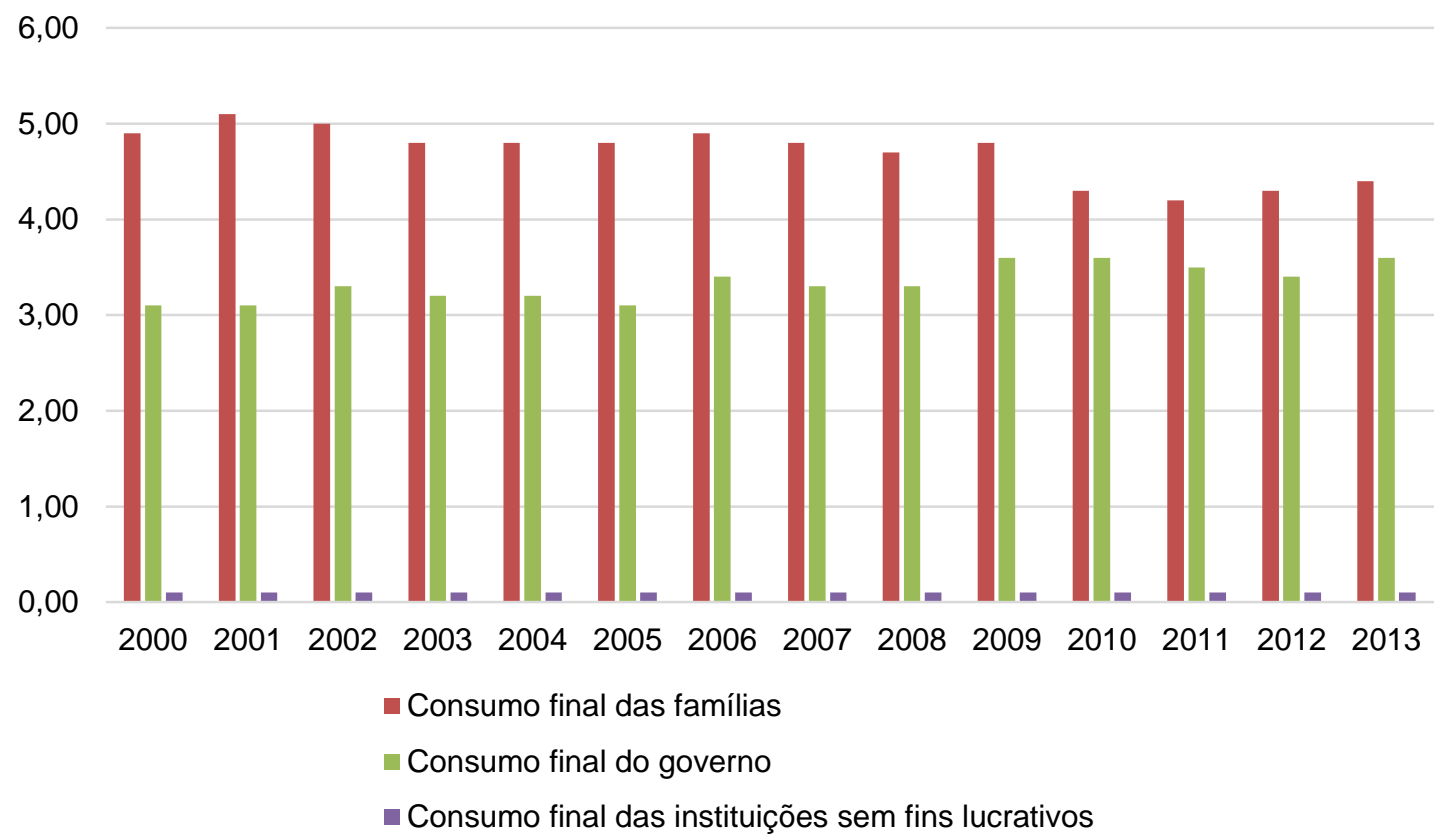

Fonte: elaboração própria com dados do IBGE

O gráfico torna visível que há, nos 13 anos analisados, uma tendência de convergência entre o consumo de bens e serviços de saúde por parte do governo e das famílias. Entre 2003 e 2010, primeiro e último ano de Lula no poder, há um aumento de $0,4 \%$ do consumo do governo como participação no PIB, enquanto as famílias apresentam uma redução de $0,5 \%$ que, a despeito de algumas oscilações ao longo do período, ocorre de uma vez entre 2009 e 2010, quando cai de 4,8\% para 4,3\%, recuperando-se para 4,4\% em 2013. Considerando-se que, entre 2008 e 2009 o financiamento por parte da administração pública saltou de 3,3\% para 3,6\%, faz sentido supor que a queda do consumo por parte das famílias seja uma resposta à ampliação da participação pública ${ }^{15}$.

A despeito da criação do SUS, portanto, os dados indicam que há certa manutenção do perfil de distribuição do mix público-privado na provisão de serviços de saúde ao longo da Nova República, matizada por uma tendência sutil de ampliação dos leitos públicos e redução dos privados, que vem acompanhada de uma queda igualmente lenta da participação das famílias no consumo de bens e serviços de saúde

\footnotetext{
${ }^{15}$ Nesse aspecto, uma outra hipótese possível é a de que a recessão econômica de 2009 tenha levado a uma queda do consumo de bens e serviços de saúde por parte das famílias. Entretanto, considerando que já em 2010 o PIB apresentou forte recuperação, mas o financiamento familiar da saúde não retomou o patamar anterior, parece coerente assumir que sua queda esteja mais vinculada à ampliação da participação governamental.
} 
e aumento do financiamento do governo. Caso houvesse uma expectativa de resiliência dessas duas tendências, era de se esperar que, num horizonte de médio prazo, o SUS conseguisse se aproximar paulatinamente de sua ambição de universalização. A conjuntura política, entretanto, não oferece sinais nesse sentido, apontando muito mais, dada a aprovação da PEC 55, para uma tendência de longo prazo de estagnação ou até redução da atuação estatal na provisão de serviços de saúde. Essa perspectiva potencializa os perigos, em termos de reprodução da desigualdade, engendrados pela divisão público/privada do sistema de saúde brasileiro herdada da ditadura militar. Isso porque, conforme ressalta Vianna (1998), aqueles que dependem mais diretamente e de forma exclusiva da rede pública são os mais pobres, incapazes de arcar com planos privados. Destarte, uma perda de recursos por parte da provisão pública terminaria por relegar toda uma população que somente tem acesso aos serviços prestados pelo Estado a condições ainda piores, aprofundando suas disparidades perante as classes médias e altas, que continuarão contando com a provisão privada.

Como possíveis saídas para esse cenário, Fleury (2009) aponta a necessidade da retomada do debate em torno da Reforma Sanitária, especialmente de sua ênfase na formação de sujeitos políticos capazes de levar adiante o projeto de universalização e humanização dos serviços de saúde. Segundo a autora, o movimento sanitário parte da perspectiva de que, para reformar o sistema e aprofundar a democratização da proteção social brasileira como um todo, é necessário que se combata as forças conservadoras em busca da construção de uma nova hegemonia que supere a predominância do discurso neoliberal. Suas bases estão em princípios como equidade, direitos sociais, universalidade, atendimento às necessidades, em detrimento a outros como individualidade, gestão eficiente e benefícios vinculados à contribuição, característicos do modelo agora hegemônico. No que tange à atuação estatal, a prática da perspectiva da Reforma Sanitária corresponderia ao aumento generoso do gasto social focado em políticas sociais universalistas, em detrimento aos repasses para a provisão privada de serviços por meio do gasto tributário, e à realização de uma política fiscal capaz de garantir o acesso a direitos por parte da população brasileira, no lugar da ênfase agora colocada na estabilidade monetária, que culmina no corte de gastos e em suas consequências negativas para o acesso ao emprego, à escola, ao atendimento médico etc. 


\subsection{Na direção de uma síntese das transformações recentes do welfare state brasileiro}

A Constituição Federal de 1988 foi um marco na história das políticas sociais brasileiras ao gerar uma inflexão normativa em direção a um modelo universalista de welfare state. Por meio dela, o legislador expressou o desejo de construir um sistema de proteção social participativo, descentralizado, focado no atendimento às necessidades e não contributivo. Trata-se, portanto, de um documento que tem, como inspiração central, o modelo inaugurado por Beveridge e aplicado de forma mais completa na social-democracia escandinava. Sua escrita foi alvo de fortes debates em torno do conflito ampliação do gasto social versus saneamento orçamentário do Estado, nos quais os movimentos sociais fizeram-se presentes e, muito provavelmente por isso, e não apenas por boa vontade da Assembleia Constituinte, a Carta convirja tanto na direção da cidadania social. Sua transformação em realidade material, porém, mostrou-se um trajeto mais tortuoso que sua formulação enquanto norma legal: a prevalência da sociedade civil organizada em torno de seus interesses nem sempre foi suficiente para fazer valer as determinações da $\mathrm{CF}$, de modo que, em determinados momentos, grupos contrários ao aumento da atuação estatal, como os empresários, mostraram também sua força. Foi assim que o SUS, após longo atraso, foi instituído, mas teve seu financiamento mutilado. É assim também que, até hoje, a educação básica pública ainda não alcançou patamares considerados mínimos pela OCDE. A Previdência, por outro lado, indexada ao salário-mínimo e incluindo as populações rurais, teve forte avanço e foi central para a queda da desigualdade experimentada na última década, mas sofreu constantes reformas que também mutilaram seu orçamento e tornaram-na menos acessível.

Neste capítulo, busquei ressaltar que, nesse caminho tortuoso trilhado ao longo dos anos 90 e 2000, duas tendências tiveram destaque: a primeira delas, consequência direta da Constituição, consiste na ampliação da participação pública na seguridade social, com aumento dos gastos sociais, maior abrangência da Previdência, a criação do SUS e aumento da provisão estatal de serviços de saúde. Nesse processo, o que se tornou mais notável foi o crescimento vertiginoso dos gastos em assistência social, especialmente das chamadas políticas de renda condicionada, inovação institucional da década de 90 e que se fortalece ainda mais nos governos do PT. Além disso, também foi crucial na dinâmica da assistência social do período o crescimento do 
BPC, puxado pela valorização real do mínimo e pela flexibilização de seus critérios de acesso.

A segunda, marcada pelo aumento e/ou manutenção de uma grande parcela de provisão privada de serviços sociais, tem origem menos certa. Por um lado, há elementos de dependência da trajetória anterior que criam inércias em termos de engenharias institucionais possíveis para políticas públicas. Assim, o sistema dual de saúde público/privado criado na ditadura militar, mesmo com o SUS, mantém-se forte, embora a provisão pública de leitos tenha passado por algum crescimento ao longo dos governos Lula e Dilma, ao mesmo tempo que há uma lenta tendência de aumento do gasto público com saúde e queda do gasto das famílias. Por outro, há uma série de inovações institucionais das gestões petistas que convergiram para mecanismos de proteção social característicos do modelo liberal ou anglo-saxão, mesmo que respondendo a demandas antigas. É assim que o Programa Universidade para Todos, muito embora venha normatizar uma isenção fiscal já concedida aos provedores privados de educação superior, somado ao FIES, gera um adensamento desse sistema privado e o legitima, na medida em que confere a ele o cumprimento de uma determinada função pública.

Nesse bojo de criações de políticas públicas de inspiração liberal também devemos inserir o PBF. O benefício, política de governo de Lula e Dilma, ao adotar condicionantes para o acesso e focar exclusivamente nos mais pobres, terminou por se aproximar do modelo de transferências com teste de meios característico dos EUA. Nesse sentido, contrasta, em termos de desenho de política, com o BPC, que tem um viés universalista e beveridgeano de provisão de uma renda mínima, sem a necessidade de contrapartidas a serem dadas pelo público-alvo. Conforme argumentei aqui, contudo, essa oposição é muito mais formal do que prática, sendo a atuação articulada das duas políticas, somada à valorização do salário-mínimo e a seu papel de indexador da Previdência, alguns dos elementos principais para a redução da pobreza extrema brasileira e para o aumento do poder de consumo dos menos abastados.

Por fim, o período da Nova República experimentou um crescimento simultâneo da atuação pública e privada na seguridade social e na provisão de serviços em geral, ao mesmo tempo que foi marcado por inovações institucionais de tipo liberal - como o ProUni e o PBF - e universal - como o SUS e o BPC. Embora essa configuração público/privada se mostre de forma diferente dependendo do tipo 
de política social analisado - na educação fundamental, 90\% do gasto é público; na saúde, o consumo das famílias é majoritário -, ela aponta para uma tendência geral de conformação de um welfare state de tipo híbrido no Brasil. Não se trata, portanto, somente de um universalismo estendido posterior ao universalismo básico da ditadura militar, como queria Kerstenetzky (2012) mas, sim, da construção de um novo regime de políticas sociais em torno de dois eixos principais: um universalista/público, e outro liberal/privado. Esse sistema encontra algumas de suas origens em decisões tomadas no passado, como no caso da saúde, porém, foi também pensado em grande medida no período da Nova República e especialmente nos governos petistas. Nele, identificar qual elemento é predominante, além de ser tarefa difícil devido às variações da importância dos elementos segundo o tipo de política social, não me parece tarefa útil, nem em termos analíticos, nem em termos práticos. Mais importante do que isso é ressaltar a centralidade do Estado em seu processo de construção, estando ele presente na configuração do sistema privado de saúde durante a ditadura, na concessão de isenções fiscais para os provedores privados, e também nas transferências de renda. Além disso, faz-se mister ressaltar a convergência entre esses dois eixos, a despeito de seus desenhos institucionais divergentes, como a interação entre BPC e PBF no combate à pobreza deixa claro. Isso, é evidente, não significa que a arquitetura desse welfare state seja ideal e que não haja conflitos internos em seu mecanismo: na saúde e na educação básica, por exemplo, os subsídios dados sob a forma de gasto tributário poderiam ser direcionados para a ampliação e melhoria da provisão direta pública, ao invés de financiarem a compra de serviços por parte das classes médias e altas.

Por fim, a construção desse Estado de bem-estar social híbrido público/privado deu-se de forma contingencial e conjuntural. Tratou-se de uma engenharia institucional construída paulatinamente, ao longo de mandatos de presidentes distintos com visões díspares a respeito das funções do Estado e de suas relações com o mercado e com a sociedade. Mesmo no que tange aos preceitos constitucionais, sua aplicação ou não dependia da conjuntura política do momento, de que forças que estavam em jogo e de qual predominaria, como ficou claro no debate da saúde, algumas vezes vencido pelo movimento da Reforma Sanitária, cujos objetivos eram universalistas, e em outras oportunidades dominado pelos provedores privados. A PEC 55, recentemente aprovada, demonstra a variabilidade do welfare state brasileiro, 
afetando profundamente a capacidade estatal de dar materialidade às normas constitucionais no que tange aos direitos sociais. Nesse sentido, o futuro de nosso regime de políticas sociais é incerto, mas, para compreendê-lo, é necessário conhecer de maneira cada vez mais profunda sua dinâmica histórica e suas transformações recentes. 


\section{Considerações Finais}

Este trabalho teve como objetivo fazer uma interpretação das transformações no welfare state brasileiro após a Constituição Federal de 1988, especialmente nos governos Lula e Dilma (2003-2016). Nesse sentido, a opção feita foi de realizar uma discussão teórica sobre os regimes de welfare tipificados por Esping-Andersen (1990), seguida de um breve estudo do percurso histórico das políticas sociais no país, para, então, entrar efetivamente na análise do objeto proposto.

No primeiro capítulo, vimos os três modelos principais de Estados de bem-estar social contidos no trabalho clássico de Esping-Andersen (1990). O primeiro deles, que corresponde à origem histórica do welfare state, é o regime conservador ou corporativo, fundado por Bismarck na Alemanha. Nesse modelo, a seguridade social é distribuída segundo as categorias funcionais, de modo que os benefícios sociais são concedidos de acordo com os vínculos empregatícios. Esse regime, ainda que consiga atingir boa parte da população nos países centrais e tenha promovido o acesso pioneiro aos direitos sociais na Europa, apresenta limitações na medida em que tende a reproduzir as desigualdades herdadas do mercado, pois as profissões mais bem posicionadas no âmbito produtivo costumam, também, receber a proteção social de forma mais generosa.

O segundo modelo é o liberal ou anglo-saxão, característico da Inglaterra anterior à Segunda Guerra Mundial, dos EUA e de demais ex-colônias inglesas, notavelmente Austrália e Nova Zelândia. Nesse regime, o welfare state tende a intervir na relação capital/trabalho de forma menos direta, enfatizando políticas compensatórias, especialmente as focalizadas de combate à pobreza. A provisão de serviços sociais como saúde e educação cabe muito à iniciativa privada, ainda que o Estado a financie indiretamente por meio de isenções fiscais. Nos países caracteristicamente liberais, como os EUA, a incidência de desigualdade tende a ser elevada para os padrões da OCDE, apontando para o potencial redistributivo inferior de suas políticas sociais (KERSTENETZKY, 2012).

O terceiro regime é o social-democrata ou escandinavo, cujo exemplo mais acabado consiste no welfare state sueco. Nele, a atuação estatal na atividade econômica é bastante larga, não somente por meio de regulação, mas também pela produção. Além disso, cabe ao setor público a provisão universal de serviços sociais e 
a concessão de generosas transferências de renda para boa parte dos cidadãos. Diferentemente dos regimes liberais, onde as classes médias e altas recorrem aos serviços privados de maior qualidade, nos países do cluster social-democrata a educação e saúde públicas deram saltos qualitativos importantes ao longo do século XX visando atender os desejos da classe média ascendente. Para financiar esse amplo aparato de proteção social, esses países apresentam, também, algumas das maiores tributações do mundo, de modo que o gasto do governo e também a arrecadação constituem volumes bastante consideráveis dos PIBs nacionais.

Entre esses três modelos, como vimos no capítulo dois, aquele que se mostrou mais próximo da experiência brasileira de proteção social ao longo do século $\mathrm{XX}$ foi o bismarckeano ou corporativo. Dessa forma, na primeira onda de expansão do welfare state brasileiro, o Estado benefactor (VIANNA, 1978) engendrado pela ditadura estadonovista era caracterizado pela ampliação da atuação estatal no campo econômico somada à inclusão dos setores subalternos à política por meio do esquema da cidadania regulada (SANTOS, 1979), configurando um regime no qual, assim como na Alemanha de Bismarck, a seguridade social era concedida segundo o vínculo empregatício. Nesse modelo, os sindicatos serviam ao mesmo tempo como vias de canalização da participação popular e de controle estatal, esvaziando, em certo sentido, o aspecto radical da contestação da sociedade ao regime e atrelando elementos conservadores à estrutura corporativa montada por Vargas (VIANNA, 1978). Entre os principais sustentáculos institucionais desse modelo estavam os IAPs, que, vinculados a categorias ocupacionais específicas, tinham recursos financeiros díspares e concediam benefícios variáveis. Assim, um dos IAPs mais generosos era o dos bancários, enquanto o dos operários apresentava uma menor gama de serviços sociais (VIANNA, 1998).

No interregno democrático de 1946-1964, embora tenham ocorrido uma série de movimentos políticos e a sociedade civil tenha retomado sua capacidade de mobilização, em termos de políticas sociais, não houve notáveis avanços reais. Após esses período, a ditadura civil-militar instaurada pelo golpe de 1964 engendrou a segunda onda de expansão do welfare state brasileiro, na qual a criação do INPS, unificando a estrutura de provisão de todos os IAPs, e do FUNRURAL, que concedia benefícios previdenciários desvinculados de contribuições passadas, representam os maiores ataques ao regime corporativo instituído por Vargas e apontam para uma rota 
mais universalista de políticas sociais. Tais ampliações de cobertura, ademais, se deram em níveis muito baixos de qualidade e variedade dos serviços providos, fazendo com que Kerstenetzky (2012) denominasse esse período de "universalismo básico". Como vimos, contudo, na saúde, a ditadura engendrou uma virada privatista da seguridade social brasileira, criando, em paralelo ao ramo contributivo herdado dos IAPs, um ramo público - focado nos mais pobres - e um privado - voltado para as classes médias e altas - de provisão de serviços (VIANNA, 1998). Para financiar a mercantilização do setor de saúde, os governos militares introduziram mecanismos até então desconhecidos de nosso repertório de políticas sociais, como as deduções fiscais do imposto de renda - o chamado welfare fiscal -, além de, para fomentar a provisão privada, fazerem o INPS demandar uma série de serviços dos hospitais privados. A partir dessa estrutura, inauguram uma tendência de liberalização das políticas sociais brasileiras que irá se reproduzir em outros setores, especialmente na educação, ao longo da Nova República.

A Constituição Federal de 1988 foi o grande marco a partir do qual se estruturaram as disputas em torno do welfare state brasileiro após a retomada da democracia (FLEURY, 2008). Marcada por uma visão beveridgeana das políticas sociais, a CF, fruto das aspirações da sociedade civil em intensa movimentação, funcionaria como o grande impulso na direção da concepção de um Estado de bemestar social de tipo social-democrata no Brasil. Seu contraponto, porém, viria na ação das elites empresariais que, munidas de um discurso contrário ao aumento da intervenção estatal e especialmente de impostos (REIS, 2000), formariam o grupo antagônico por excelência à ampliação dos gastos sociais do Estado brasileiro. Além disso, a resiliência de opções feitas nos regimes anteriores, como a criação do ramo de saúde privado na ditadura militar, criariam dependências da trajetória de difícil modificação por parte dos governos democráticos, de modo que, durante as gestões petistas, ainda que haja ampliação constante da provisão pública de leitos e do gasto estatal com saúde, a participação privada ainda é majoritária.

Nesse sentido, os governos do PT tiveram como característica principal a combinação de duas arquiteturas de políticas sociais distintas: na assistência social, por um lado, percebemos a ênfase em políticas universais, com a expansão e aumento do BPC via indexação ao salário-mínimo e, por outro, o fortalecimento de programas de transferência de renda focalizadas, como o PBF, que vinham multiplicando-se 
desde a década de 1990. Na saúde e na educação, a participação pública, embora tenha apresentado crescimento na primeira e na criação de universidades federais, foi acompanhada de perto pela complexificação e desenvolvimento do setor privado de ambos os serviços, com a manutenção da importância da participação privada na provisão de leitos somada à expansão sem precedentes do ensino superior privado, impulsionado por políticas como o Prouni e o Fies.

A partir dessa estrutura de proteção social que combina iniciativas universais/públicas e focalizadas/privadas, o welfare state nacional toma, entre $2003 \mathrm{e}$ 2016, uma forma dual e híbrida, na qual combinam-se elementos de dois regimes de welfare distintos: o liberal ou anglo-saxão e o social-democrata ou escandinavo. Essa ambiguidade rompeu com o predomínio histórico das influências corporativas no país. Gerou, além disso, novos mecanismos institucionais melhor capacitados para fazer frente as suas desigualdades estruturais, combinando a ação focalizada em grupos historicamente marginalizados à ampliação da provisão universal de serviços. Promoveu, assim, ainda que de forma restrita, a ascensão social de grupos subalternos, configurando um regime de bem-estar específico com características próprias. 


\section{Referências bibliográficas}

AGUIAR, Vilma. Um balanço das políticas do governo Lula para a educação superior: continuidade e ruptura. Revista de Sociologia e Política, v. 24, no 57, p. 113-126, 2016.

ARTS, Will A.; GELISSEN, John. "Models of the welfare state" In: CASTLES, Francis G.; LEIBFRIED, Stephan; LEWIS, Jane; OBINGER, Herbert; PIERSON, Christopher (Orgs.). The Oxford Handbook of the Welfare State. Oxford: Oxford University Press, 2010.

BENEVIDES, Claudia do Valle. Um Estado de bem-estar social no Brasil? Dissertação de mestrado. Niterói: Programa de Pós-graduação em Economia da Universidade Federal Fluminense, 2011.

BRASIL. Decreto $n^{\circ} 1.637$, de 5 de janeiro de 1907. Crea syndicatos profissionaes e sociedades cooperativas. Disponível em: http://www2.camara.leg.br/legin/fed/decret/1900-1909/decreto-1637-5-janeiro-1907582195-publicacaooriginal-104950-pl.html. Acesso em: 2 de janeiro de 2017.

BRASIL. Decreto $\mathrm{n}^{\mathrm{o}} 3.724$, de 15 de janeiro de 1919. Regula as obrigações resultantes dos accidentes no trabalho. Disponível em: http://www2.camara.leg.br/legin/fed/decret/1910-1919/decreto-3724-15-janeiro-1919571001-publicacaooriginal-94096-pl.html. Acesso em 2 de janeiro de 2017.

BRASIL. Decreto $n^{\circ} 4.682$, de 24 de janeiro de 1923. Crea, em cada uma das empresas de estradas de ferro existentes no país, uma Caixa de Aposentadoria e Pensões para os respectivos empregados. Disponível em: http://www81.dataprev.gov.br/sislex/paginas/23/1923/4682.htm. Acesso em: 2 de janeiro de 2017.

BRASIL. Decreto n 19.770 , de 19 de março de 1931. Regula a sindicalização das classes patronais e operárias e dá outras providências. Disponível em: http://www2.camara.leg.br/legin/fed/decret/1930-1939/decreto-19770-19-marco1931-526722-publicacaooriginal-1-pe.html. Acesso em: 2 de janeiro de 2017.

BRASIL. Decreto $n^{\circ} 23.768$, de 18 de janeiro de 1934. Regula a concessão de férias aos empregados na indústria, sindicalizados. Disponível em: http://www2.camara.leg.br/legin/fed/decret/1930-1939/decreto-23768-18-janeiro1934-526823-publicacaooriginal-1-pe.html. Acesso em: 2 de janeiro de 2017.

BRASIL. Lei $\mathrm{n}^{\circ}$ 3.807, de 26 de agosto de 1960. Dispõe sobre a Lei Orgânica da Previdência Social. Disponível em: http://www2.camara.leg.br/legin/fed/lei/19601969/lei-3807-26-agosto-1960-354492-publicacaooriginal-1-pl.html. Acesso em: 2 de janeiro de 2017.

BRASIL. Decreto-lei $\mathrm{n}^{\mathrm{o}}$ 72, de 21 de novembro de 1966. Unifica os Institutos de Aposentadoria e Pensões e cria o Instituto Nacional de Previdência Social. Disponível em: $\quad$ https://www.planalto.gov.br/ccivil_03/decreto-lei/1965-1988/Del0072.htm. Acesso em: 2 de janeiro de 2017.

BRASIL. Lei complementar $n^{\circ} 7$, de 7 de setembro de 1970. Instituiu o Programa de Integração Social, e dá outras providências. Disponível em: http://www.planalto.gov.br/ccivil_03/leis/LCP/Lcp07.htm. Acesso em: 2 de janeiro de 2017. 
BRASIL. Lei complementar $n^{\circ}$ 19, de 25 de junho de 1974. Dispõe sobre a aplicação dos recursos gerados pelo Programa de Integração Social (PIS) e pelo Programa de Formação do Patrimônio do Servidor Público (PASEP), e dá outras providências. Disponível em: http://www.planalto.gov.br/ccivil_03/leis/LCP/Lcp19.htm. Acesso em: 2 de janeiro de 2017.

BRASIL. Lei complementar $n^{\circ} 26$, de 11 de setembro de 1975. Altera disposições da legislação que regula o Programa de Integração Social (PIS) e o Programa de Formação do Patrimônio do Servidor Público (PASEP). Disponível em: http://www.planalto.gov.br/ccivil_03/leis/LCP/Lcp26.htm\#art7. Acesso em: 2 de janeiro de 2017.

BRASIL. Lei $\mathrm{n}^{\mathrm{o}}$ 12.435, de 6 de julho de 2011. Altera a Lei no 8.742, de 7 de dezembro de 1993, que dispõe sobre a organização da Assistência Social. Disponível em: http://www.planalto.gov.br/ccivil_03/_Ato20112014/2011/Lei/L12435.htm\#art1. Acesso em: 5 de janeiro de 2017

CARDOSO, Adalberto. Uma utopia brasileira: Vargas e a construção do Estado de bem-estar numa sociedade estruturalmente desigual. DADOS, v. 53, n. 4, pp. 775$819,2010$.

CARLEIAL, L.; MALAGUTI, M.L. Informalidade e precarização no mercado de trabalho brasileiro. Mimeo. 2001.

CASTLES, Francis G. Comparative Public Policy: Patterns of Post-war Transformation. Cheltenham: Edward Elgar, 1998.

CASTLES, Francis G.; MITCHELL, Deborah. Worlds of welfare and families of nations. In: Families of Nations: Patterns of Public Policy in Western Democracies, ed. Francis G. Castles, Aldershot: Dartmouth, 93-128, 1993.

CASTRO, José Abrahão de; CARDOSO JR., José Celso. Políticas sociais no Brasil: gasto social do governo federal de 1988 a 2002. In: JACCOUD, Luciana (org.). Questão social e políticas sociais no Brasil contemporâneo. Brasília: IPEA, 2009.

CORBUCCI, P.R. Financiamento e democratização do acesso à educação superior no Brasil: da deserção do Estado ao projeto de reforma. Educação \& Sociedade, v. 25, no 88, pp.677-701, 2004.

DRAIBE, S. The Brazilian Developmental Welfare State: Rise, Decline and Perspectives. In: RIESCO, M. (ed.), Latin America: A New Developmental Welfare State in the Making? UNRISD/Palgrave-Macmillan, Basingstoke, 2007.

ESPING-ANDERSEN, G. The Three Worlds of Welfare Capitalism. New Jersey: Princeton University Press, 1990.

FERRERA, M. The south European countries. In: CASTLES, F.; LEIBFRIED, S; LEWIS, J.; OBINGER, H.; PIERSON, C. (eds.). The Oxford Handbook of the Welfare State. Oxford: Oxford University Press, 2010. p. 616-630.

FLEURY, Sonia. Retomar o debate sobre a Reforma Sanitária para avançar o Sistema Único de Saúde (SUS). Revista de Administração de Empresas, v. 49, no 4, pp. 472-480, 2009.

FLEURY, Sonia. Seguridade social: um novo patamar civilizatório. In: Instituto Legislativo Brasileiro. Os cidadãos na carta cidadã. Brasília: Senado Federal, 2008. 
GUERREIRO, M. Análise dos gastos sociais brasileiros na perspectiva do Estado de bem-estar social 1988-2008. Dissertação de mestrado. Niterói: Programa de Pósgraduação em Economia da Universidade Federal Fluminense, 2010.

HERMANN, Jennifer. Reformas, Endividamento Externo e o "Milagre" Econômico (1964-1973). In: GIAMBIAGI, F.; VILLELA, A.; CASTRO, L.; HERMANN, J.; (orgs.). Economia Brasileira Contemporânea: 1945-2004. Rio de Janeiro: Campus/Elsevier, 2011.

IBGE. Conta-satélite de saúde do Brasil 2010-2013. Rio de Janeiro, 2015.

INEP. Dados do Censo Escolar da Educação Básica de 2015. Brasília, 2015.

IPEA. TD 1500, Ipea 46 anos. O Brasil em 4 décadas. Brasília, 2010.

IPEADATA. Disponível em: http://www.ipeadata.gov.br. Acesso em: janeiro de 2017.

KAUTTO, Mikko. "The Nordic countries". In: CASTLES, Francis G.; LEIBFRIED, Stephan; LEWIS, Jane; OBINGER, Herbert; PIERSON, Christopher (Orgs.). The Oxford Handbook of the Welfare State. Oxford: Oxford University Press, 2010.

KERSTENETZKY, Celia Lessa. O Estado do bem-estar social na idade da razão: a reinvenção do Estado social no mundo contemporâneo. Rio de Janeiro: Elsevier, 2012.

KORPI, Walter; PALME, Joakim. The paradox of redistribution and the strategy of equality: Welfare state institutions, inequality and poverty in the Western countries. American Sociological Review, 63 (5): 661-87, 1998.

KUHNLE, Stein; SANDER, Anne. The emergence of the Western welfare state. In: CASTLES, Francis G.; LEIBFRIED, Stephan; LEWIS, Jane; OBINGER, Herbert; PIERSON, Christopher (Orgs.). The Oxford Handbook of the Welfare State. Oxford: Oxford University Press, 2010.

LEAL, Victor Nunes. Coronelismo, Enxada e Voto: O município e o regime representativo no Brasil. São Paulo: Companhia das Letras, 2012.

LEIBFRIED, Stephan, and RIEGER, Elmar. Limits to Globalization: Welfare State Reasons for Economic Openness or Closure. Stanford, CA \& Mannheim: European Forum, Stanford University \& MZES, Mannheim University (reproduced MS), 1997.

MDS. Censo SUAS 2014. Análise dos componentes sistêmicos da Política Nacional de Assistência Social. Brasília, 2015.

MINTO, L.W. A educação da "miséria": particularidade capitalista e educação superior no Brasil. Tese de Doutorado. Campinas: Universidade Estadual de Campinas, 2011.

NULLMEIER, Franz; KAUFMANN, Franz-Xaver. Post-war welfare state development. In: CASTLES, Francis G.; LEIBFRIED, Stephan; LEWIS, Jane; OBINGER, Herbert; PIERSON, Christopher (Orgs.). The Oxford Handbook of the Welfare State. Oxford: Oxford University Press, 2010.

PIERSON, Christopher; LEIMGRUBER, Matthieu. "Intellectual Roots". In: CASTLES, Francis G.; LEIBFRIED, Stephan; LEWIS, Jane; OBINGER, Herbert; PIERSON, Christopher (Orgs.). The Oxford Handbook of the Welfare State. Oxford: Oxford University Press, 2010. 
Programme for International Student Assessment. Results from PISA 2015: Brazil. 2015.

POLANYI, Karl. A grande transformação: as origens de nossa época. Rio de Janeiro: Elsevier, 2013.

PRZEWORSKI, Adam. Capitalism and social democracy. Cambridge: Cambridge University Press, 1985.

REIS, Elisa P. Política e Políticas Públicas na Transição Democrática. In: A. S. de Moura. (Org.). O Estado e as Políticas Públicas na Transição Democrática. São Paulo: Vértice, 1989, p. 90-104.

REIS, Elisa P. Percepções da elite sobre pobreza e desigualdade. Revista Brasileira de Ciências Sociais, v. 15, n.42, p. 143-152, 2000.

RODGERS, Daniel T. Atlantic Crossings: Social Politics in a Progressive Age. Cambridge, MA: The Belknap Press of Harvard University Press. 1998.

SANTOS, Wanderley Guilherme dos. Cidadania e Justiça. A Política Social na Ordem Brasileira. Rio de Janeiro: Ed. Campus, 1979.

SKOCPOL, Theda. Protecting Soldiers and Mothers: the political origins of social policy in the United States. Cambridge: Harvard University Press, 1995.

TAYLOR-GOOBY, P. The Silver Age of the Welfare State: Perspectives on Resilience. Journal of Social Policy, 31(4), pp. 597-621, 2002.

VIANNA, Luiz Werneck. Liberalismo e sindicato no Brasil. Rio de Janeiro: Paz e Terra, 1978.

VIANNA, Maria Lucia Werneck. A americanização perversa da seguridade social no Brasil. Rio de Janeiro: Editora Revan, 1998. 